\title{
Hatim Gazali
}
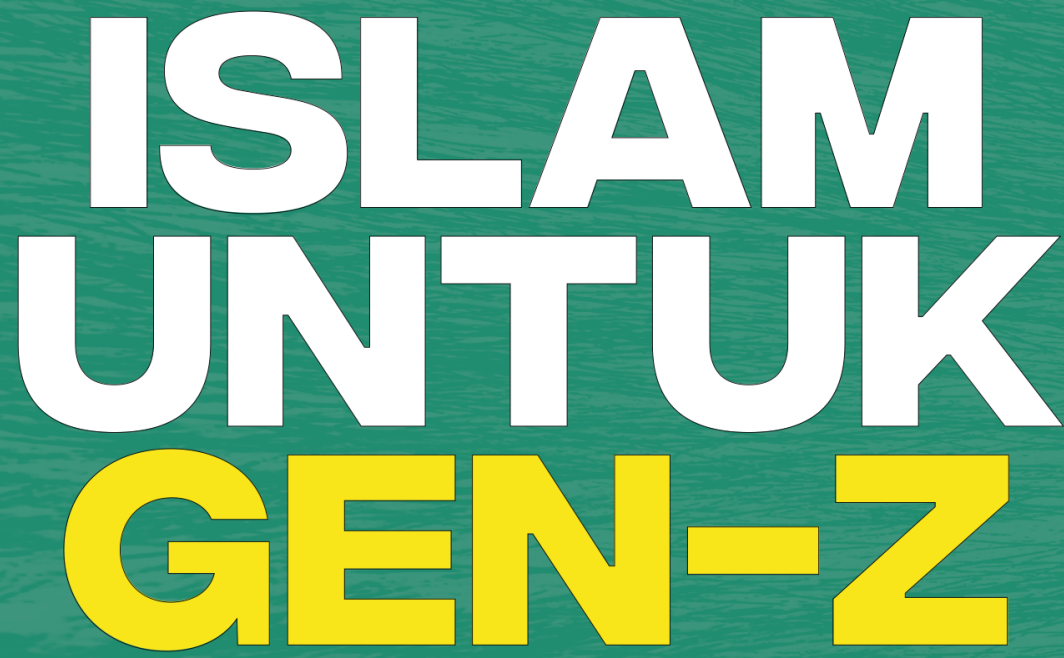

MENGAJARKAN ISLAM \& MENDIDIK MUSLIM GENERASI Z; PANDUAN BAGI GURU PAI

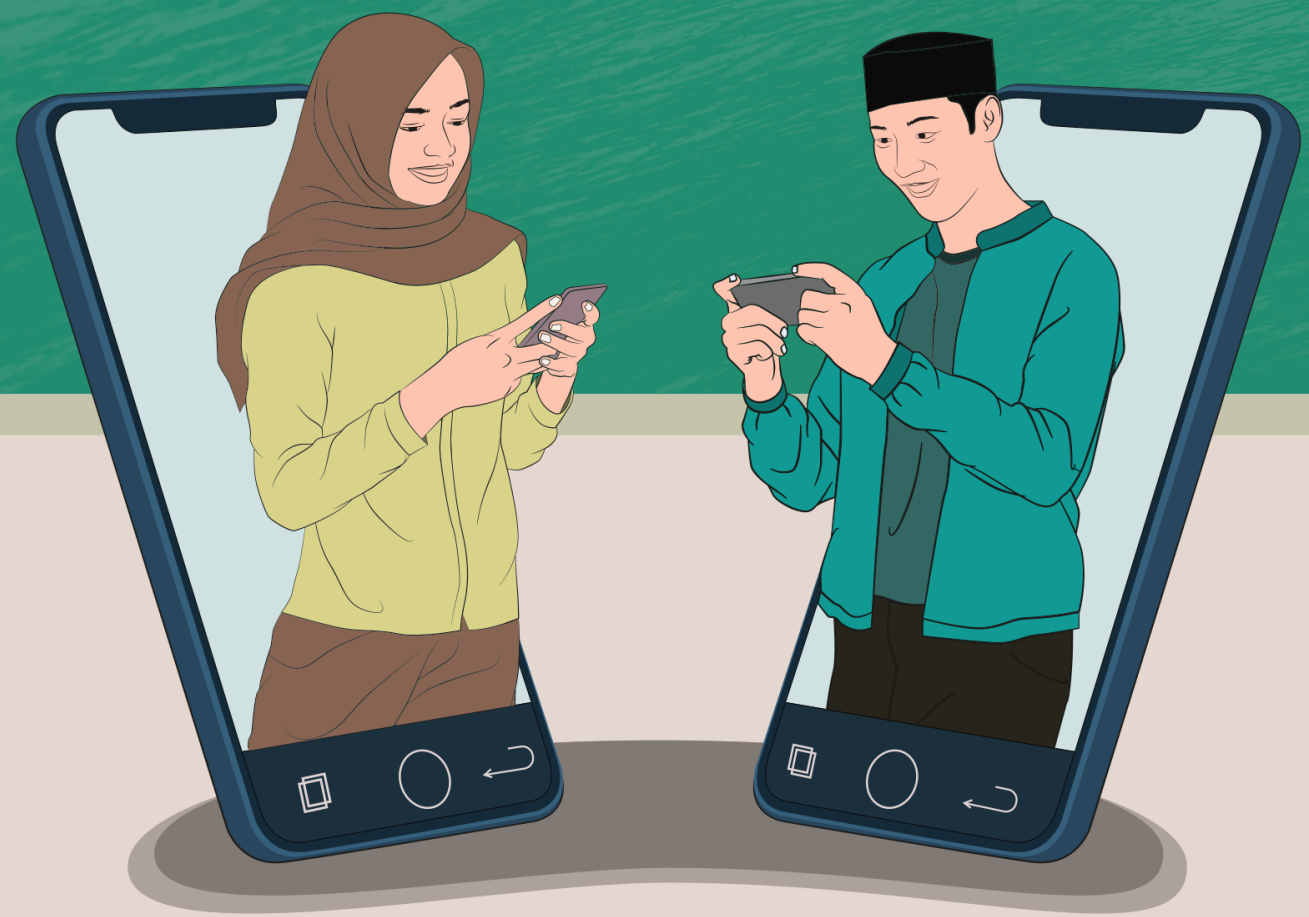




\section{Sanksi Pelanggaran Pasal 113}

\section{Undang-undang Nomor 28 Tahun 2014 tentang Hak Cipta}

(1) Setiap orang yang dengan tanpa hak melakukan pelanggaran hak ekonomi sebagaimana dimaksud dalam pasal 9 ayat (1) huruf i untuk penggunaan secara komersial dipidana dengan pidana penjara paling lama 1 (satu) tahun dan/atau pidana denda paling banyak Rp100.000.000,00 (seratus juta rupiah).

(2) Setiap orang yang dengan tanpa hak dan/atau tanpa izin pencipta atau pemegang hak cipta melakukan pelanggaran hak ekonomi pencipta sebagaimana dimaksud dalam pasal 9 ayat (1) huruf $c$, huruf $d$, huruf $f$, dan/atau huruf h untuk penggunaan secara komersial dipidana dengan pidana penjara paling lama 3 (tiga) tahun dan/ atau pidana denda paling banyak Rp500.000.000,00 (lima ratus juta rupiah).

(3) Setiap orang yang dengan tanpa hak dan/atau tanpa izin pencipta atau pemegang hak cipta melakukan pelanggaran hak ekonomi pencipta sebagaimana dimaksud dalam pasal 9 ayat (1) huruf a, huruf b, huruf e, dan/atau huruf g untuk penggunaan secara komersial dipidana dengan pidana penjara paling lama 4 (empat) tahun dan/ atau pidana denda paling banyak Rp1.000.000.000,00 (satu miliar rupiah).

(4) Setiap orang yang memenuhi unsur sebagaimana dimaksud pada ayat (3) yang dilakukan dalam bentuk pembajakan, dipidana dengan pidana penjara paling lama 10 (sepuluh) tahun dan/atau pidana denda paling banyak Rp4.000.000.000,00 (empat miliar rupiah). 


\section{ISLAM UNTUK GEN-Z}

Mengajarkan Islam \& Mendidik Muslim Generasi Z; Panduan Bagi Guru PAI

HATIM GAZALI 


\section{ISLAM UNTUK GEN-Z}

Mengajarkan Islam \& Mendidik Muslim Generasi Z;

Panduan Bagi Guru PAI

Penulis : Hatim Gazali

Editor : Siti Kholisoh dan Khoirul Anam

Design \& Layout : Oktanta Tri H. \& Pinandito Anjas Wicaksono

Penyelia Aksara : Davida Ruston Khusen

Sampul : Pinandito Anjas Wicaksono

Halaman : 144 halaman

Ukuran $\quad: 15,5 \times 23 \mathrm{~cm}$

Cetakan ke-1 Juni 2019

Diterbitkan Wahid Foundation

ISBN 978-602-7891-13-5

\section{WAHID FOUNDATION}

Griya Gus Dur, Jl. Taman Amir Hamzah No. 8 Pegangsaan Menteng Jakarta Pusat 10320

Telp : +62 $21-3145671$

Faks : +62 $21-3928250$

Media@wahidinstitute.org www.wahidfoundation.org

FB Wahid Foundation

Twitter@Wahidfoundation

IG@Wahidfoundation 


\section{DAFTAR ISI}

\section{PENGANTAR}

\section{BAB SATU}

MENGENALKAN ISLAM UNTUK GEN-Z

Ciri dan Karakteristik

Cara Belajar Generasi Z

Mengajarkan Islam

\section{BAB DUA}

CARA MEMPELAJARI ISLAM

Bayan Ilahi

Bayan Nabawi

Bayan Aqli

\section{BAB TIGA}

MENJAWAB POKOK MASALAH AKIDAH

Bid'ah Sumber Kerusakan Islam?

Menjadi Firqah An-Näjiyah

Pengertian dan Macam-Macam Kafir 


\section{BAB EMPAT}

MENJAWAB POKOK MASALAH FIKIH

Islam Tidak Bermazhab

Hukum Hanya Milik Allah

64

Haramnya Ziarah Kubur

70

Bersalaman dengan Lawan Jenis

78

Aurat Perempuan

82

\section{BAB LIMA}

MENJAWAB POKOK MASALAH SIYASAH

89

Mengenal Konsep dan Model Khilafah

89

Apakah Demokrasi Haram?

Keharusan Mencintai Negara

Hormat Bendera, Haramkah?

\section{BAB ENAM}

ADAKAH ISLAM RADIKAL?

DAFTAR PUSTAKA 


\section{PRAKATA PENULIS}

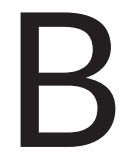

agi Arkin dan Ibra yang berumur 9 tahun, mendapatkan informasi tentang apa saja bukan perkara sukar. Termasuk tentang ilmu-ilmu keislaman. Baginya, belajar Islam itu tidak hanya melalui guru kelas di sekolahnya, ataupun guru di madrasahnya. Begitu pun dengan Davi yang sebentar lagi akan masuk sekolah menengah. Mereka dengan mudah dapat mengakses bermacam-macam informasi tentang Islam melalui telepon genggam yang di tangannya. Bahkan, guru agamanya dengan mudah dikoreksi dan disodorkan pelbagai pertanyaan berdasarkan ilmu yang didapatkan melalui Youtube.

Sementara bagi Bu Nisa, guru agama sekolah menengah, tetap bertekad mengajarkan Islam seperti yang la dapatkan di sekolah dan universitas Islam pada 30 tahun yang lalu. Meminta anak menghafal surat-surat pendek plus dengan artinya. Berceramah di ruang kelas hal ihwal salat, wudu dan bersuci. "Coba hafalkan surat al-Qadr beserta artinya”, perintah Bu Nisa kepada murid-murid di sekolahnya. Perintah dengan setengah memaksa ini harus dilakukan Bu Nisa, karena nanti akan masuk dalam lembar ujian yang akan diberikan di tengah semester.

Berbeda dengan Pak Aldi, lulusan pendidikan Fisika universitas terkemuka, yang diminta mengajar pendidikan agama di sekolah pinggir Jakarta setelah menunaikan ibadah haji 3 tahun lalu. Baginya mengajarkan agama Islam adalah panggilan jiwa. Sebuah kesadaran yang lahir setelah rutin 
pengajian di kompleknya dalam 5 tahun terakhir ini. Dengan mengajarkan agama Islam, la bercita-cita membentuk generasi muda yang saleh, hafal al-Quran. Tak perlu dibayangkan bagaimana Pak Aldi yang notabene lulusan pendidikan Fisika mengajarkan Pendidikan Agama Islam di kelas. Cukup modal niat dan semangat.

Begitulah gambaran yang jamak terjadi dalam ruang kelas Pendidikan Agama Islam. Pada satu sisi, murid yang dihadapinya adalah Generasi Z yang sangat melekat dengan dunia internet, doyan mengakses Youtube, termasuk ceramah-ceramah ustaz dan kiai. Pada sisi lain, sejumlah guru agama di sekolah dihadapkan pada isu kecakapan menghadapi Generasi $Z$, selain tentunya kompetensi yang dimilikinya. Karena itulah tak perlu kaget, jika pada saat-saat tertentu, siswa mengajukan pertanyaan di luar materi. Apalagi sifat pertanyaannya tingkat tinggi. Atau, siswa memprotes karena apa yang disampaikan guru berbeda dengan apa yang ia dengar di Youtube dan Instagram.

Terlebih, seperti yang kita tahu, informasi di internet begitu sangat melimpah dan beragam. Penggunanya sering tak mengetahui apakah informasi yang diaksesnya itu valid atau tidak, hoax atau bukan. Belum lagi, perbedaan pandangan tentang Islam yang dengan mudah dapat dijumpai di internet. Bagi ustaz X, suatu hal itu haram, tapi tidak bagi ustadz Y.

Nah, buku di tangan anda ini adalah ikhtiar kecil untuk memberikan acuan atau bahan bacaan, yang insyaallah bersumber pada sumber hukum yang valid. Karena situasi Pendidikan Agama Islam di kelas demikian adanya, maka penulis mengawalinya dengan topik "bagaimana mengenalkan Islam kepada Generasi Z", sebuah topik yang tidak saja mengajak para guru mengerti dunia Gen Z, mulai dari karakteristik sampai cara belajarnya, tetapi juga langkah-langkah apa yang perlu dipersiapkan guru menghadapi Gen Z ini. Kemudian, disusun dengan "cara mempelajari Islam" yang menekankan bahwa Islam memiliki perangkat ilmu pengetahuan yang kompleks, sehingga kita tidak dengan mudah mengklaim sebagai satusatunya sumber kebenaran tentang Islam. Karenanya, pada bagian ini diulas perangkat ilmu apa saja untuk mengetahui dan memahami alQuran, Hadis dan bagaimana menggunakan "akal sehat" untuk memahami 
kedua sumber ajaran Islam tersebut. Bab ini membawa pada kesadaran-sekurang-kurangnya-bahwa menghafal ayat al-Quran sekaligus menghafal artinya tidak serta-merta dapat dikategorikan sebagai ahli Islam, karena di dalamnya ada banyak perangkat ilmu lain yang diperlukan.

Setelah itu, pada bab-bab berikutnya, penulis berikhtiar untuk menjawab sejumlah pokok persoalan terkait dengan akidah, fikih dan politik. Tentu saja, ini jauh dari kata cukup. Pokok soal yang dijabarkan pada buku ini terkait dengan hal-hal yang kerap menjadi tanda tanya bagi siswa dan Guru PAI. Sebagai upaya untuk mainstreaming Islam rahmatan lil ālamin, pada bagian penutup, penulis mengulas ihwal Islam radikal, sebuah terminologi yang pada satu sisi kadang menyakitkan hati umat Islam, namun pada sisi lain kita menjumpai orang-orang yang dengan mudah mengajak melakukan kekerasan yang diyakininya sebagai perintah ajaran Islam.

Akhirnya, buku ini tentu tak segera selesai jika tidak ditopang oleh sejumlah orang yang bergerak dengan kapasitasnya masing-masing. Tersebutlah misalnya Mba Olis dan Mas David dari Wahid Foundation yang turut serta mendiskusikan rancangan buku ini, mulai saat berupa embrio sampai pada pengejaran penyelesaian penulisan buku ini. Juga, saya berterima kasih kepada Dewi Anggraini, Dosen PAI di Universitas Negeri Jakarta dan Universitas Nahdlatul Ulama, dan Rohmatul Faizah, Dosen PAI di UPN Surabaya yang turut iuran pemikiran sampai buku ini rampung dan hadir di hadapan pembaca.

Tentunya, sebagai sebuah jihad dan ijtihad, buku ini hanyalah awal mula, bukan akhir. Karena penulis bercita-cita untuk terus menghadirkan sejumlah sumber bacaan baik bagi guru maupun siswa yang sedang belajar agama Islam. Sebagai ijtihad, tentu jika ada hal yang salah ataupun kurang lengkap, maka dengan rendah hati, penulis secara terbuka siap mendiskusikannya lebih lanjut. Wallahu 'a'lam

Kramat Raya, 3 Juli 2019

Hatim Gazali

PRAKATA ix 


\section{PENGANTAR}

\section{WAHID FOUNDATION}

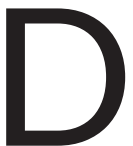

alam Sejarah Aliran-Aliran dalam Islam (al-Mażāhib al-Islamiyyah) terbitan Darul Fikr, guru besar hukum Islam Universitas Kairo Mesir Syaikh Muhammad Ahmad Abu Zahrah menunjukkan fakta tentang sejarah umat Islam yang tak tunggal, meski berasal dari sumber yang sama: al-Quran. Mulai dari aliran politik, akidah, dan fikih. Dari Sunni, Syiah, hingga Khawarij, dari Jabbariyah hingga Mu'tazilah, bahkan "sektesekte" di dalam sekte-sekte yang disebut itu. Contohnya dalam khawarij yang memiliki sejumlah sekte dari Azariqah, al-Ajaridah hingga Ibadhiyyah.

Syaikh Abu Zahrah juga membahas apa yang ia sebut sebagai mażāhib hadisah, aliran-aliran baru, seperti Wahabi, Baha'i, Qadiyan. Keragaman aliran ini dalam sejarahnya memang tidak hanya menampilkan perbedaan doktrin dan tafsir, malahan sebagian berujung konflik kekerasan. Masih menurut Syaikh Abu Zahrah, perbedaan ini memang hal yang hampir tak terhindarkan karena beberapa faktor. Di antaranya perbedaan pemikiran, perbedaan persepsi, taklid pada para pendahulu, hingga karena perkara kepemimpinan dan kecintaan pada penguasa.

Pandangan ini memang tidak sejalan dengan pandangan sebagian pihak yang meyakini bahwa Islam hanya satu: Islam. Tak ada embel-embel lain. Sebagai ajaran dalam hal-hal pokok, Islam memiliki wajah tunggal. Namun, Islam sebagai komunitas dan fakta sosiologis kenyataannya memang tak 
pernah tunggal. Islam di Indonesia punya corak ekspresi yang berbeda dengan di Eropa dan Timur Tengah. Bahkan corak ekspresi keislaman masyarakat Jawa dengan Minang atau Banjar.

Di sinilah pentingnya usaha-usaha umat untuk mendorong umat selalu belajar atau mendapat informasi yang tepat tentang Islam, komunitas Islam, dan keragaman yang ada di dalamnya. Cara semacam ini penting untuk membentuk sikap yang bijak, tidak emosional, dan tepat dalam memahami dan merespons pandangan atau praktik yang dianggap tak sesuai dengan keyakinan atau pandangan kelompok kita sendiri.

Pengetahuan semacam itu juga dibutuhkan untuk merespons dan mengatasi kelompok-kelompok tertentu yang justru "memanfaatkan", $\mathrm{KH}$ Abdurrahman Wahid menyebut dengan kata "membajak"-Islam sebagai alat yang bertentangan dengan pesan dasar Islam itu sendiri. Misalnya mereka yang menjadikan alasan Islam untuk membenarkan tindakan intoleransi, radikalisme, termasuk terorisme dengan tafsir doktrin jihad sebagai semata-mata perang atau al-wala' 'wa al-barā', loyalitas dan berlepas diri, untuk memusuhi dan melakukan aksi kekerasan terhadap aparat negara yang sah dan kelompok lain yang dianggap tidak sejalan.

Buku ini sebetulnya ditujukan sebagai salah satu usaha untuk membekali para penceramah (mubalig) dan guru-guru agama mengenali gambar besar tentang konsep-konsep kunci dalam Islam yang terbentang dari isu-isu teologis (tauhid), ibadah ('ubudiyyah), gerakan (harakah). Buku ini juga menyajikan diskusi mengenai isu-isu aktual yang muncul dan kadang membingungkan bagi sebagian orang seperti khilafah dan hormat bendera.

Dengan pertimbangan bahwa mubalig dan guru-guru agama adalah aktor penting mempertahankan wajah Islam moderat di Indonesia, mereka jelas sekali memerlukan asupan informasi yang diperlukan untuk menopang usaha-usaha mulia mereka.

Tentu saja kami sadar bahwa tidak semua pandangan yang disajikan penulis akan cocok dan bisa diterima para pembaca. Tapi dari sana justru diskusi 
dan perbincangan dapat terus dikembangkan; buku dan karya-karya sejenis dihasilkan.

Kami berterima kasih kepada Hatim Gazali pengajar di Universitas Sampoerna dan Pengurus Rabithah Ma'ahid Islamiyah (RMI) PBNU atas kerja kerasnya menyusun buku ini. Juga Siti Kholisoh, Khoirul Anam, Davida Ruston Khusen yang menyunting dan terlibat dalam penerbitan buku ini. Kami berharap buku ini ikut memberi manfaat bagi kemajuan umat Islam di masa depan.

Rumah Pergerakan Gus Dur Wahid Foundation 


\section{BAB SATU}

\section{MENGENALKAN ISLAM UNTUK GEN-Z}

$\mathrm{H}$ al-hal pokok dalam Islam tidak pernah berubah. Apa yang ada dalam al-Quran dan hadis Nabi adalah kebenaran, tak pernah mengalami perubahan. Keduanya absolut (qath'i); mengubah kedua sumber tersebut adalah kesalahan besar.

Tetapi, tafsir atau interpretasi terhadapnyaterus mengalami perkembangan sesuai dengan perubahan ruang dan waktu. la bersifat relatif (zanny). Di bidang tafsir, kita memiliki beragam jenis kitab tafsir yang antara satu dengan lainnya tak pernah sama persis. Di bidang hukum Islam atau fikih, kita juga memiliki -sekurang-kurangnya-4 mazhab (aliran) yang berbeda-beda; Imam Hanafi, Imam Malik, Imam Syafii dan Imam Ahmad bin Hambal. Karena bersifat relatif, tak ada satu tafsir yang lebih benar dari tafsir lainnya.

Cara mempelajari Islam pun berkembang. Di masa Nabi, Islam diajarkan langsung oleh Nabi melalui metode hafalan dan persaksian (pengamatan) langsung terhadap perilaku Nabi yang belakangan berbentuk hadis 
dan sunnah. Ketika Nabi menerima wahyu, para sahabat diminta untuk menghafalkannya dan menuliskannya. Sebagai panutan dan pedoman, apa yang didengarkan dan dilihat dari Nabi adalah menjadi sumber hukum yang harus dipatuhi. Melalui pendengaran dan penglihatan sahabat terhadap Nabi itulah yang kemudian disebut sebagai hadis.

Seiring dengan perkembangan zaman, muncullah masalah-masalah baru yang sebelumnya tak pernah ada di masa Nabi. Dengan tetap berpegang teguh pada kedua sumber tersebut, para sahabat melakukan terobosan berupa ijtihad sehingga masalah-masalah baru dapat dipecahkan.

Islam semakin menyebar ke belahan dunia lainnya. Orang-orang yang mempelajari Islam pun makin banyak jumlahnya. IImu-ilmu dalam keislaman pun terus berkembang pesat. Transmisi pengetahuan yang paling masif saat itu dilakukan melalui tulisan yang tersebar ke dalam sejumlah literatur tentang keislaman yang di kalangan pesantren disebut Kitab Kuning, sebuah buku yang menggunakan kertas berwarna kuning, menggunakan Bahasa arab tanpa harakat. Itu adalah satu-satunya sumber ilmu pengetahuan saat itu.

Belakangan ini, sumber ilmu pengetahuan tak lagi terpusat ke dalam format teks berupa tulisan dalam buku dan kitab-kitab, melainkan juga dalam format video, foto dan bentuk multimedia lainnya. Akibatnya, dalam mengajarkan dan mempelajari Islam tidak bisa hanya berpatokan kepada satu format sumber belajar. Melainkan harus menggunakan segala bentuk format yang memudahkan seseorang belajar.

Terlebih, Generasi Z memiliki karakteristik belajar yang berbeda dengan generasi sebelumnya. Karena itulah, penting kiranya mengetahui bagaimana karakteristik Generasi Z, dan bagaimana memanfaatkan sumber belajar tersebut secara maksimal.

Karena itulah, bagian ini mengulas tentang 1) ciri dan karakteristik Generasi $Z$, 2) Bagaimana mengajarkan Islam kepada Gen-Z dengan memanfaatkan sumber belajar sehingga dalam mempelajari Islam tidak terkesan menoton dan membosankan, tetapi mengasyikkan dan sekaligus bermakna. 


\section{Ciri dan Karakteristik}

Adalah Karl Mannheim yang mula-mula memperkenalkan teori generasi melalui bukunya yang berjudul "The Problem of Generation". Menurutnya, setiap manusia akan saling memengaruhi dan membentuk karakter yang cenderung sama. Ini karena manusia menghadapi dan melewati sosiosejarah yang sama. Artinya, manusia yang mengalami perang Dunia I akan berbeda karakternya dengan manusia yang menghadapi perang dunia II. Begitu seterusnya.

Dari teori inilah, para sosiolog Amerika Serikat membagi generasi manusia ke dalam beberapa generasi yang didasarkan pada waktu lahirnya. Generasi Era Depresi, Generasi Perang Dunia II, Generasi Pasca-PD II, Generasi Baby Boomer I, Generasi Baby Boomer II, Generasi X, Generasi Y alias Milenial, Ialu Generasi Z. Karena proses identifikasinya berdasarkan tahun lahir, maka berikut adalah karakteristiknya

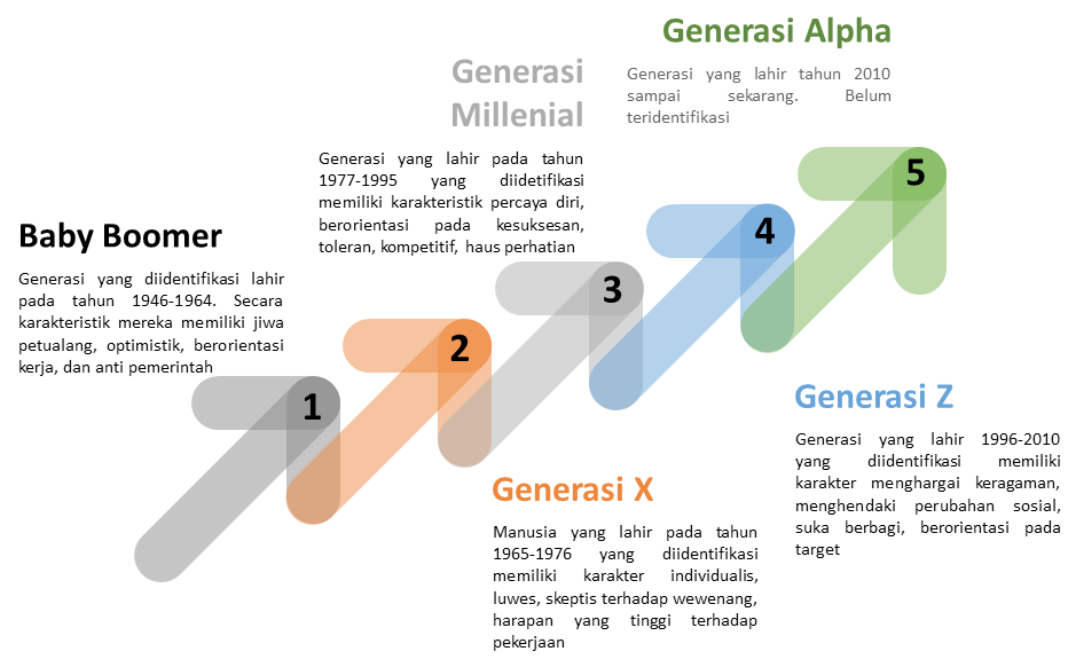

Kesalahpahaman terjadi ketika kita menganggap bahwa setiap manusia yang lahir pada tahun tertentu pasti menjadi kelompok generasi tertentu. Misalnya, generasi yang lahir di rentang 1977-1995 pasti dianggap generasi milenial. Kenapa dianggap kesalahan, karena ia hanya mengidentifikasi berdasarkan tahun lahir bukan pada sosio-sejarah yang membentuknya. 
Jika kita konsisten pada teori generasi di atas, bahwa pembagiannya berdasarkan pada sosio-sejarah yang membentuk, maka seseorang yang lahir pada periode 1997-1995 di satu negara tertentu akan memiliki karakteristik yang berbeda dengan orang di negara yang lain. Misalnya, sama-sama lahir pada periode 1996-2010, anak yang lahir di pedesaan yang sangat terbelakang tentu berbeda dengan anak yang lahir di perkotaan yang sudah maju, karakteristiknya akan berbeda.

Singkatnya, pembagian generasi tersebut tidak serta hanya berdasarkan pada waktu lahir, tetapi juga harus memperhatikan sosio-sejarah pembentuknya, sehingga tidak perlu generalisasi. Untuk itu, Generasi $Z$ tidak cukup hanya dicirikan berdasarkan tahun lahir, melainkan juga sosio-historis yang dihadapinya. Salah satu ciri yang sangat kuat dari Generasi Z adalah akses dan ketergantungan terhadap teknologi, gadget dan pelacakan informasi secara acak. Mereka bukan generasi yang secara tekun membaca suatu narasi melalui buku-buku cetak. Sebaliknya, mereka lebih enjoy terhadap informasi yang bertebaran di dunia internet, terutama yang berbentuk visual dan gambar.

Mari kita fokus kepada Generasi Z yang sedang kita hadapi di kelas-kelas di mana kita mengajar. Seperti apa karakteristik mereka? Secara sederhana, mereka memiliki karakteristik sebagai berikut:

\section{(2) MULTI TASKING}

Mereka dapat mengerjakan beragam hal secara bersamaan

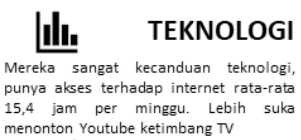

TERBUKA

Mereka memiliki jiwa vang terbuka terhadap hal-hal baru, dan mencoba halhal baru

\section{a Audo visual}

Mereka lebih suka Audio visual ketimbang teks/tulisan, karena itulah mereka lebih suka melihat gambar ketimbang tulisan artikel

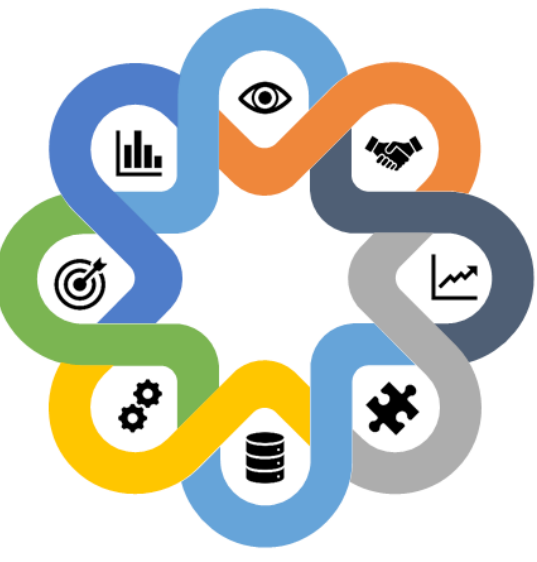

\section{KREATIF}

Mereka adalah generasi yang kreatif, tidak puas dengan kemapanan yang ado

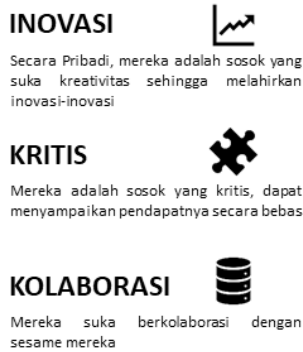


Dari gambar di atas, dapat dijelaskan bahwa:

1. Multi-Tasking. Generasi Z ini dapat mengerjakan beberapa pekerjaan secara bersamaan, mereka bisa mengetik di laptop sembari mendengarkan lagu dari internet, mengakses media sosial melalui gawai, mencari referensi penting untuk menyelesaikan tugas, dan menonton TV.

2. Teknologi. Mereka adalah generasi yang memiliki ketergantungan yang tinggi terhadap teknologi, terutama yang berbasis internet. Rata-rata per hari mereka bisa menghabiskan waktu 3-5 jam untuk mengakses media sosial.

3. Terbuka. Berkat media sosial tersebut, mereka adalah generasi yang terbuka terhadap hal-hal baru, mudah penasaran terhadap kebaruan termasuk mencoba hal-hal baru.

4. Audio-visual. Mereka adalah generasi yang lebih menikmati audio dan visual ketimbang teks tulisan, sehingga gambar, video, grafis dan bentuk audio-visual lainnya lebih disukai.

5. Kreatif. Banyaknya informasi yang didapatkan melalui gadget yang dimilikinya, menjadikan mereka sebagai sosok yang kreatif.

6. Inovatif. Mereka adalah sosok yang tidak puas dengan keadaan hari ini, karena itulah, mereka berusaha untuk memunculkan inovasi-inovasi yang dapat mempermudah hidupnya.

7. Kritis. Dengan teknologi di genggamannya, mereka dapat mengakses beragam informasi secara acak, sehingga menjadikan mereka kritis dalam membaca sesuatu karena sumber yang dibaca tidak pernah tunggal.

8. Kolaborasi. Di tangan mereka, era kompetisi seakan berakhir. Mereka lebih menikmati kolaborasi sesama generasi mereka untuk memecahkan masalah yang dihadapinya.

Karena ciri dan karakteristiknya yang demikian, menghadapi Generasi Z tidak bisa sama dengan menghadapi generasi sebelumnya. Para guru atau dosen seringkali mengeluh dan membandingkan apa yang dialaminya dulu sewaktu bersekolah dengan siswa yang dihadapinya. Mereka seringkali lupa bahwa zaman terus bergerak, dan kita seringkali gagap untuk mengikuti perkembangan zaman tersebut. 


\section{Cara Belajar Generasi Z}

Survei-survei yang dilakukan Varkey Foundation pada 2017 di 20 negara tentang faktor penentu kebahagiaan Generasi Z menyebutkan bahwa ternyata anak-anak muda Indonesia paling banyak menganggap komitmen terhadap agama sangat penting dalam memengaruhi kondisi kebahagiaan mereka dengan skor 93\%. Di bawah faktor agama, terdapat faktor-faktor lain yang menentukan kebahagiannya; kenyamanan dalam kehidupan, sekolah atau pekerjaan, hubungan baik dengan teman, hubungan baik dengan keluarga, sehat secara mental dan fisik.

Survei di atas pada satu sisi membanggakan namun pada sisi lain mengkhawatirkan. Disebut membanggakan karena anak didik kita memiliki semangat yang tinggi untuk belajar agama. Hingga demikian semangatnya, mereka seringkali tidak cukup puas dengan apa yang didapatkan pada pelajaran Pendidikan Agama Islam (PAI) di sekolah, karenanya mereka juga menambah tempat dan waktu belajar di majelis, madrasah dan pesantren-pesantren.

Akan tetapi, bisa juga menjadi kekhawatiran jika apa yang dipelajarinya tidak sesuai dengan ajaran Islam yang diajarkan oleh Nabi Muhammad, tidak mendapatkan guru yang tepat, serta cara mengajarkannya yang tidak sesuai dengan gaya belajar mereka.

Kekhawatiran tersebut dapat terkonfirmasi dengan sejumlah hasil penelitian. Survei Wahid Foundation tahun 2016 terhadap kalangan aktivis Rohani Islam (Rohis) menyebutkan bahwa 86\% aktivis Rohis SMA ingin berjihad ke Suriah. Mereka banyak terpapar informasi keagamaan yang penuh kecurigaan, kebencian, cenderung mengingkari atau menentang pemenuhan hak-hak kewarganegaraan terhadap kelompok lain yang tidak disukai, dan cenderung mendukung tindakan dan gerakan radikal.

Survei Pusat Studi Islam dan Transformasi Sosial (CIS Form) UIN Sunan Kalijaga menemukan bahwa generasi muda lebih nyaman mencari pembelajaran keagamaan melalui media online dan model pembelajaran 
di luar kelas. Karena itulah, sebagian dari mereka lebih mengidolakan dan memercayai apa yang disampaikan ustaz di media sosial ketimbang gurunya di kelas. Tak heran, guru agama di sekolah tak banyak diikuti pendapatnya, dibanding ustaz di media sosial. Padahal, pendidikan agama yang didapatkan sang guru tersebut memiliki porsi yang besar dalam memengaruhi mereka untuk bergaul dengan siapa.

Survei Pusat Pengkajian Islam dan Masyarakat (PPIM) UIN Jakarta 2017 menemukan bahwa mayoritas guru beragama Islam di Indonesia memiliki opini intoleran dan radikal yang tinggi. PPIM menemukan sebanyak 10,01 persen guru muslim punya opini sangat intoleran secara implisit dan 53,06 persen memiliki opini yang intoleran secara implisit. Selain itu, 6,03 persen guru muslim memiliki opini sangat intoleran dan 50,87 persen guru memiliki opini intoleran secara eksplisit.

Sebagai hasil survei, kondisi ini tentu mengkhawatirkan, karena Generasi $\mathrm{Z}$ ini adalah cerminan masa depan Indonesia. Karena itulah, perlu ada terobosan baik dari level guru maupun cara mengajarkan agama Islam.

Berikut adalah gaya belajar Generasi Z.

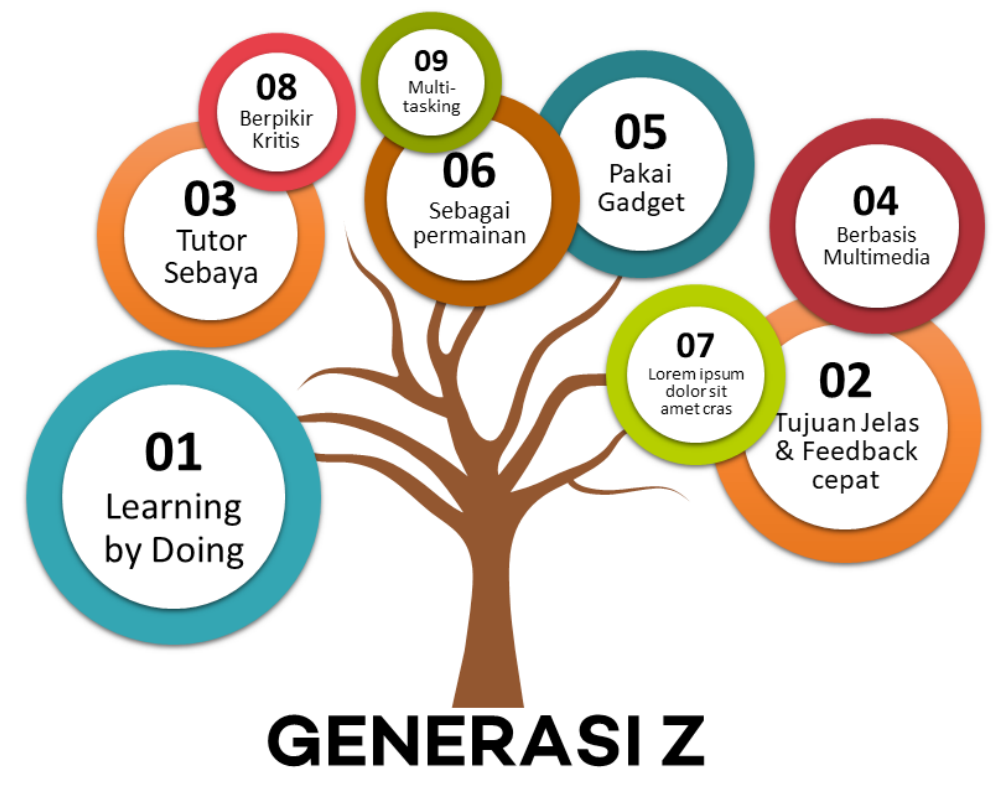


Dari gambar di atas, dapat dijelaskan sebagai berikut:

1. Learning by doing. Generasi Z lebih menyukai cara belajar yang menekankan praktik ketimbang duduk di bangku.

2. Tujuan jelas dan feedback cepat. Salah satu yang menentukan motivasi belajar siswa adalah tujuan yang jelas dan pemberian umpan balik secara cepat oleh guru. Siswa akan termotivasi belajar jika apa yang dipelajarinya memiliki tujuan yang jelas, sekaligus mendapat umpan balik terhadap proses dan hasil belajarnya.

3. Tutor Sebaya. Generasi Z lebih merasa nyaman belajar ketika guru menempatkan dirinya sebagai tutor sebaya; mengajar dengan pendekatan personal, tidak menggurui dan tidak galak terhadap mereka. Mereka adalah generasi yang ingin dipahami dan dihargai dengan segala kompleksitas persoalan yang dihadapinya. Karena itu, berbicara secara personal, memberikan saran terhadap masalah yang dihadapinya akan sangat menyenangkan bagi mereka.

4. Berbasis multimedia. Sebagaimana yang telah disebutkan pada subbab sebelumnya, Generasi Z sangat enjoy ketika sumber belajarnya dihadirkan dalam bentuk multimedia, baik visual, gambar, video, grafis dan lain sebagainya.

5. Menggunakan gawai (gadget). Sebagai generasi yang sangat lekat dengan gawai, Generasi Z akan menggunakan smartphone di genggamannya untuk belajar. Dengan cara ini, maka sumber belajar yang dapat dikembangkan tidak hanya berupa teks, melainkan juga dalam format lain yang memungkinkan untuk diakses melalui gawainya.

6. Belajar sebagai permainan. Generasi $Z$ bukan pribadi yang secara spesifik belajar sesuatu dengan cara yang serius dan monoton. Sebaliknya, mereka lebih suka belajar dengan gaya bermain

7. Berpikir kritis. Informasi yang didapatkan melalui dunia internet, menjadikan mereka kaya informasi yang pada gilirannya menjadikan mereka kritis. Karena itulah, mereka dapat membandingkan apa yang 
disampaikan oleh guru di kelas dengan apa yang didapatkan melalui media sosial.

8. Multitasking. Seperti yang dijelaskan pada sub-bab sebelumnya, karena kemampuan multitasking tersebut, aktivitas pembelajaran untuk Generasi Z sebaiknya bervariasi, tidak menoton. 


\section{Mengajarkan Islam}

Lalu, bagaimana menerapkannya dalam format pembelajaran agama Islam? Guru dan Dosen Pendidikan Agama Islam (PAI) sedari awal harus memiliki prinsip sebagai berikut:

Pertama, relasi guru-murid. Dalam konteks Generasi Z, relasi guru-murid berbeda dengan generasi-generasi sebelumnya. Menghadapi Generasi Z, seorang guru/dosen tidak bisa menempatkan diri sebagai sosok yang tak terjangkau, angker dan menakutkan. Sebaliknya, guru atau dosen sejatinya perlu memposisikan dirinya sebagai sebaya untuk murid-muridnya, sehingga dapat mendorong proses belajar secara lebih menyenangkan dan mendapatkan hasil maksimal. Jika guru atau dosen diposisikan sebagai sosok yang menakutkan, maka siswa tidak akan berani untuk bertanya lebih mendalam dan personal terkait dengan masalah yang dihadapinya. Sementara itu, Generasi Z yang sedang kita hadapi adalah generasi yang secara periode umur berada dalam ketidakstabilan. Ada banyak persoalan personal dan psikologis yang mereka hadapi. Mereka membutuhkan sosok guru yang bisa mendengarkan keluhan mereka.

Dengan cara inilah, seorang guru atau dosen tidak serta merta melakukan judgment terhadap masalah yang dihadapi siswa dan mahasiswa. Sebaliknya, seorang guru atau dosen mesti mengembangkan sikap simpati dan empati terhadap persoalan mereka.

Kedua, guru bukan satu-satunya sumber ilmu atau informasi. Perlu diingat bahwa Generasi Z adalah generasi yang tidak terpisahkan dari teknologi dan media sosial. Mereka dapat mengakses beragam informasi melalui gawai yang ada di tangannya. Bahkan, bukan hal mustahil, apa yang disampaikan guru atau dosen dapat dibantah melalui referensi yang mereka cari di dunia internet. Karena itulah, berikan kesempatan kepada mereka untuk berpikir, mencari informasi sebanyak-banyaknya terkait pertanyaan yang mereka punya atau yang ingin diketahui, lalu kemudian dibahas secara bersama-sama. 
Dengan tidak menjadikan dirinya sebagai satu-satunya sumber informasi, maka seorang guru atau dosen dapat menerima masukan dan kritik serta pendapat yang berbeda sebagai hasil dari dari sumber lain yang diakses oleh siswa. Tidak perlu apriori dan antipati terhadap setiap pendapat yang dikemukakan oleh siswa yang berbeda dengan pendapat guru atau dosen. Justru, hal tersebut menjadi momentum bagi guru atau dosen untuk mendiskusikan lebih mendalam, metodologis, dan terstruktur, sehingga pengetahuan dan wawasan siswa dapat diarahkan.

Ketiga, gaya belajar. Perlu dipahami, gaya belajar setiap siswa pasti berbeda-beda, dan setiap generasi memiliki keunikan tersendiri. Anak yang memiliki kecenderungan visual yang kuat sebaiknya tak dipaksakan mengikuti gaya belajar auditori melalui ceramah-ceramah yang diberikan oleh guru atau dosen. Yang harus dilakukan adalah, guru atau dosen dapat menyesuaikan dengan gaya belajar siswa. Dalam konteks pembelajaran di kelas, guru atau dosen secara kreatif dapat mengembangkan model pembelajaran secara variatif, tidak melulu hanya ceramah. Mengerti gaya belajar siswa akan menjadi kunci sukses dalam mengajarkan Islam kepada mereka. Dampaknya, Islam akan dapat dipelajari secara menyenangkan, cepat dan benar.

Keempat, sediakan waktu di luar kelas. Perlu diketahui bahwa peserta didik kita mendapatkan pelajaran agama tidak hanya di ruang kelas. Di luar kelas, mereka sering mengikuti kegiatan-kegiatan keagamaan untuk memperdalam pengetahuannya. Bahkan, mereka sering memanfaatkan gawainya untuk mencari informasi dan wawasan tentang Islam melalui internet. Ini terjadi karena seringkali guru atau dosen menyediakan waktu kepada peserta didiknya hanya di dalam kelas. Karena itu, agar terhindar dari pemahaman Islam yang tidak benar, sebaiknya guru atau dosen dapat memanfaatkan jam di luar kelas untuk memperdalam agama. Kegiatankegiatan tutorial yang kerapkali dilakukan di sekolah dan kampus perlu terus digalakkan. 
Dengan memegang keempat prinsip di atas, lalu bagaimana sebaiknya mengajarkan Islam di dalam kelas, yakni Pendidikan Agama Islam sebagai mata pelajaran atau mata kuliah, kepada Generasi Z?

Sekurang-kurangnya ada 4 pendekatan yang dapat digunakan guru atau dosen dalam mengajarkan Islam. Pertama, berbasis masalah dan project. Agar apa yang dipelajari benar-benar bermanfaat dalam kehidupan kesehariannya, maka Pendidikan Agama Islam perlu menerapkan pembelajaran berbasis masalah. Siswa dan atau guru dapat mengembangkan masalah yang terjadi di sekitar atau masalah-masalah yang kerap menjadi kontroversi. Seorang guru tak perlu merasa takut untuk mendiskusikan masalah-masalah yang sekiranya sensitif atau kontroversi, seperti hukum mengucapkan Selamat Natal, apa makna jihad yang sebenarnya, dst.

Topik-topik yang ada dalam buku pelajaran kiranya tak hanya dibahas secara normatif, melainkan harus mempelajari kasus-kasus yang terjadi di masyarakat. Misalnya, ketika mengajarkan bab salat, ajaklah siswa untuk mempelajari bagaimana pandangan ulama mazhab tentang salah satu bacaan atau gerakan salat.

Selain pada itu, pendekatan pembelajaran berbasis project juga perlu dilakukan. Misalnya, ketika di dalam kelas belajar tentang topik zakat, maka guru dapat mendesain dan mengarahkan tugas untuk siswa. Salah satu bentuk tugasnya, misalnya, adalah cara menghitung zakat. Nah, guru dapat mengambil salah satu contoh orang-orang yang wajib zakat, lalu meminta mahasiswa untuk menghitungnya, berapa kira-kira zakat yang harus dikeluarkan. Atau misalnya, ketika ada seseorang yang meninggal di sekitar sekolah, guru dapat mengajak siswa untuk belajar secara riil tentang pembagian harta waris, siapa yang berhak menerima waris dan bagaimana jika terjadi sengketa di antara ahli waris.

Kedua, sebagai Generasi Z, ajak siswa untuk benar-benar memanfaatkan teknologi dan internet secara maksimal sebagai alat belajar, mulai dari pemanfaatan untuk presentasi, menggali informasi, baik oleh siswa 
maupun dosen, dan lain sebagainya. Dalam mengajarkan suatu topik, guru biasanya hanya mengandalkan ceramah berdasarkan buku pelajaran yang ada. Padahal, guru dapat mengembangkan beberapa media belajar berbasis teknologi sehingga pembelajaran yang berlangsung menyenangkan bagi siswa. Hal yang paling sederhana, gunakan Power Point, masukkan foto atau gambar dan video sebagai sumber belajar, sehingga guru tidak hanya mengandalkan ceramah, melainkan juga dapat mengajak siswa untuk menonton video atau memerhatikan gambar.

Bahkan, guru atau dosen dapat merancang blended learning; sebuah model pembelajaran yang mengombinasikan pertemuan tatap muka di kelas dengan pembelajaran online. Ini tentu akan sangat menyenangkan. Sejumlah penelitian menunjukkan betapa blended learning dapat membantu siswa mencapai hasil belajar yang memuaskan.

Ketiga, berikan umpan balik terhadap kinerja siswa secara cepat, konstruktif dan bermakna. Umpan balik bukan hanya berisi angka-angka penilaian terhadap hasil belajar siswa, melainkan -yang terpentingmasukan atau komentar tentang hal apa yang perlu ditingkatkan atau diperbaiki dan hal apa yang telah bagus. Dengan mendapatkan umpan balik yang tepat, siswa dapat mengetahui hal-hal yang perlu ditingkatkan, dan guru juga secara reflektif dapat mengetahui praktik baik apa yang telah dilakukan di dalam kelas. Lebih jauh, mintalah siswa memberikan umpan balik tentang metode, sistem dan materi pembelajaran, sehingga guru juga dapat mengevaluasi dan melakukan refleksi terhadap pembelajaran yang terjadi.

Keempat, Critical Thinking atau Higher Order Thinking (HOT). Ajaklah siswa tidak sekadar menghafal materi, tetapi juga berpikir kritis terhadap materi yang didapatkan. Brynes menyebutkan 6 ciri pokok pembelajaran berbasis HOT, yaitu manakala siswa mampu: 1) Memvisualisasikan masalah dengan diagram atau grafik lainnya, 2) Membedakan antara informasi yang relevan dan yang tidak relevan dengan topik yang sedang didiskusikan, 3) Mencari penyebab dan alasan, 4) Membuat solusi, 5) Melihat sebuah 
masalah dengan perspektif yang berbeda/lebih dari satu perspektif, 6) Menimbang kredibilitas suatu sumber dan memutuskan apakah sumber tersebut dapat dipercaya atau tidak.

Pembelajaran berbasis HOT ini penting di tengah maraknya hoaks yang terjadi. Karena dengan sikap kritis yang dimiliki oleh siswa, maka potensi siswa dalam mengkonsumsi hoaks dapat diminimalisir. Semoga. 


\section{BAB DUA}

\section{CARA MEMPELAJARI ISLAM}

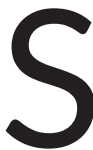

etiap muslim wajib belajar Islam. Karena dengan ilmu agama yang dimilikinya, tauhid kita benar, ibadah kita benar dan ahlak kita benar, sebagaimana yang dicontohkan oleh Nabi Muhammad Saw.

Dalam mempelajari Islam, kita perlu mencari guru yang benar, sumber yang tepat, sehingga Islam yang kita pahami benar-benar sesuai dengan ajaran-ajaran Allah dan Rasulullah.

Dalam konteks ini, menarik mengambil ibrah dari latar belakang dituliskannya kitab ar-Risalah oleh Imam Syafii. Pada suatu ketika, Imam Syafii dikirimi surat Abdurrahman al-Mahdi, seorang Gubernur Asia Tengah. Imam Syafii ini adalah imam mazhab (ulama besar) yang hidup pada masa tabi'in, lahir pada tahun $150 \mathrm{H}$. Dari segi nasab bapaknya, Imam Syafii bukan keturunan langsung Nabi Muhammad. Imam Syafii adalah putra dari Idris, bin Abbas, bin Usman, bin Syafi', bin Saaib, bin Ubaid, bin Abu Yazid, bin Hasyim, bin Muthallib, bin Abdul Manaf, bin Qusaiy, bin Qilab. 
Dalam surat tersebut, Abdurrahman al-Mahdi bertanya. "Ya Syekh, saya ingin belajar Islam yang benar, bagaimana caranya?" Mendapatkan surat itu, Imam Syafii membalas surat sang gubernur hingga 300 halaman tebalnya, yang kemudian diberi nama kitab ar-Risalah, sebuah kitab yang menjadi dasar-dasar ilmu ușū al-fiqh.

Apa jawaban Imam Syafii terhadap pertanyaan Gubernur Asia Tengah itu? Kata Imam Syafii, untuk memahami Islam dengan benar, kita harus memahami 3 hal: 1) Bayan Ilahi, yakni al-Quran 2) Bayan Nabawi, yakni hadis dan sunah Nabi, 3) Bayan 'Aqli, yakni penggunaan akal sehat. Karena itulah, bagi kita yang hendak memahami Islam dengan benar, maka kita mesti memahami ketiga hal tersebut.

Mengapa ketiga hal ini muncul? Karena kita tidak sezaman dengan Nabi. Jika di masa Nabi, setiap persoalan yang muncul selalu dapat langsung ditanyakan kepada Nabi. Namun kini, Nabi telah wafat, 1400-an tahun yang lalu, sehingga kita tidak bisa bertanya langsung kepada Nabi tentang setiap persoalan kekinian. Yang ditinggalkan oleh Nabi adalah al-Quran dan hadis. 


\section{Bayan Ilahi}

Al-Quran adalah sumber utama ajaran Islam. Dari segi isi, tidak ada perubahan sedikit pun al-Quran di masa Nabi dengan di masa sekarang. Namun, sebagaimana kita tahu, bahwa al-Quran baru dikodifikasi, disusun secara runut, dimulai pada masa sahabat. Di masa Nabi, al-Quran hanya ditulis di dedaunan, kulit unta, kulit kayu, bebatuan, tulang-tulang dan lain sebagainya. Pada saat itu, al-Quran ditulis dengan tanpa harakat, tanpa titik di huruf-huruf al-Quran, seperti titik pada huruf Qof, Fa, Ba, Jim, dan lain sebagainya. Sekalipun tanpa harakat dan titik pada huruf-huruf alQuran, para sahabat dapat membacanya dengan benar, karena masih ada para penghafal al-Quran.

Namun lambat laun, jumlah penghafal semakin berkurang karena wafat, terutama pada perang Yamamah, sementara Islam makin menyebar. Timbul persoalan bagaimana cara membaca al-Quran, karena masih belum ada tanda baca sama sekali dalam al-Quran. Sebagai contoh pada ayat 3 surah at-Taubah, saat itu ada orang yang membaca innallāha barì um minal-musyrikina wa rasūlih, yang seharusnya Innallāha barì um minal-musyrikina wa rasūluh. Apakah beda maknanya ketika harakatnya berbeda? Tentu saja sangat berbeda. Jika dibaca innallāha barì um minalmusyrikina wa rasūlih, maka ia bermakna "sesungguhnya Allah lepas dari orang-orang musyrik dan Rasulnya," bagaimana mungkin Rasul disamakan dengan orang-orang Musyrik? Maka yang benar adalah innalāha bari'um minal-musyrikina wa rasuluh, yang berarti "Allah dan Rasul-Nya lepas dari orang-orang musyrik".

Maka, Sayyidina Ali bin Abi Thalib memelopori lahirnya ilmu gramatika Arab, yang kemudian dilanjutkan oleh sahabat sekaligus muridnya, Abu Aswad ad-Duwali yang wafat pada tahun $69 \mathrm{H}$. Kemudian dilanjutkan oleh muridnya, Nasr bin 'Ashim (wafat 707 Masehi) dan Yahya bin Ya'mur (wafat 708 Masehi) yang hidup pada masa Bani Umayyah, serta Imam Khalil bin Ahmad al-Faraidi yang wafat pada tahun $185 \mathrm{H}$. 
Ini baru soal membaca al-Quran, belum sampai pada bagaimana memahami al-Quran. Memahami al-Quran tentu tidak cukup hanya dengan membaca terjemah al-Quran, tetapi juga membutuhkan seperangkat ilmu pengetahuan, mulai dari gramatika Arab seperti nahwu, saraf, 'arud, sampai pada kaidah-kaidah penafsiran. Mengapa demikian? Karena al-Quran sebagai firman Allah yang suci, model dan susunan ayatnya beragam. Ada ayat muḥkamat, ada ayat mutasyahibat, ada mutlak ada muqayyad, ada 'am, ada khas.

Pertanyaannya, apakah memberikan titik pada huruf dan harakat pada alQuran tidak menyalahi aturan syariat Islam karena tidak dicontohkan oleh Nabi? Tentu saja, tidak ada perintah dalam al-Quran maupun hadis yang menyuruh kita memberikan titik pada huruf al-Quran beserta harakatnya. Namun, jika tanpa titik dan harakat tersebut, umat Islam akan memiliki banyak sekali versi bacaan yang berbeda-beda, yang sangat mungkin salah. Melihat kemungkinan madarat yang ditimbulkan itu, para ulama berinisiatif untuk memberikan tanda titik pada huruf-huruf Arab serta harakat.

Narasi di atas disajikan untuk menggambarkan bahwa untuk memahami al-Quran tidaklah mudah. Apalagi jika masuk ke dalam ayat-ayat al-Quran beserta kandungannya. Dalam al-Quran, ada ayat-ayat yang jelas (muhkamat) ada juga ayat-ayat yang butuh ta'wil dan tafsir (mustasyabihat). Dalam al-Quran juga ada ayat-ayat yang bersifat umum ('am), ada ayat yang bersifat khusus (khaș). Belum lagi soal bagaimana proses dan latar belakang turunnya ayat tersebut, yang berpengaruh terhadap pemaknaan al-Quran.

Singkat kata, untuk memahami al-Quran, kita butuh ilmu. hadis yang diriwayatkan oleh Tirmiżi menyebutkan bahwa Rasulullah berkata "barangsiapa yang berkata mengenai al-Quran tanpa ilmu, maka ia menyediakan tempatnya sendiri di dalam neraka". Karena tidak mudahnya memahami al-Quran, lahir sejumlah kitab tafsir, baik jenis tafsir yang sifatnya penjabaran (tahlili), ijmali (global), perbandingan (muqaran), maupun tafsir tematik (maudhui'). 
Karena itu, untuk memahami al-Quran, sekurang-kurangnya kita memerlukan 16 perangkat ilmu.

1. Ilmu Mawaținal-Nuzul.Sebuah ilmu yang menjelaskan tentang tempattempat dan masa atau waktu turunnya ayat.

2. Ilmu Tawarikh al-Nuzul, ilmu yang menjelaskan tentang masa dan tertib turunnya ayat al-Quran satu demi satu dari awal hingga akhir.

3. Ilmu Asbab al-Nuzul, ilmu yang menerangkan sebab-sebab turunnya ayat al-Quran.

4. IImu Qira'at, adalah ilmu yang menjelaskan jenis-jenis bacaan alQuran. Yang cukup sahih dan terkenal adalah tujuh jenis bacaan alQuran(qiraat al-sab'ah).

5. IImu Tajwid, yakni cara membaca al-Quran, awal dan tempat berhenti membaca, seperti iżhar, idzgham, ikhfa' dan lain sebagainya.

6. Ilmu Garibal-Qur'an, ilmu yang menerangkan makna-makna yang ganjil yang ada dalam ayat al-Quran, yang pada umumnya jarang muncul dalam percakapan orang Arab.

7. Ilmu I'rabil al-Qur'an, yakni ilmu yang menjelaskan kedudukan kata dalam setiap ayat dalam al-Quran, apakah dibaca fathah, ḍmmah, kasroh dan lain sebagainya.

8. Ilmu al-Wujuh wa al-Naza'ir, yaitu ilmu yang menjelaskan tentang kata-kata dalam al-Quran yang memiliki banyak makna, menjelaskan makna yang dimaksud pada satu ayat tertentu dan makna yang berbeda pada ayat lain.

9. Ilmu Ma'rifat al-Muhkkam wa al-Mutasyabih, ilmu yang menjelaskan jenis-jenis ayat yang masuk kategori muḥkam (ayat yang memiki makna jelas dan tidak memerlukan ayat lain untuk memahaminya) dan ayat yang masuk kategori mutasyabih, kebalikan dari muhkam.

10. Ilmu al-Nasikh wa al-Mansukh, menjelaskan tentang ayat-ayat yang dianggap mansukh oleh para mufassir.

11. Ilmu Bada'i al-Qur'an, ilmu yang menjelaskan keindahan-keindahan al-Quran, seperti muatan sastra dalam al-Quran.

12. Ilmu Tanașub Ayat al-Qur'an, ilmu yang menjelaskan keterkaitan satu ayat dengan ayat lain dalam al-Quran, 
13. Ilmu Aqsam al-Qur'an, ilmu yang menjelaskan tentang maksud dan arti dari sumpah-sumpah Allah dalam al-Quran, seperti "demi masa"

14. Ilmu Amsal al-Qur'an, ilmu yang menjelaskan perumpaan-perumpaan dalam al-Quran.

15. Ilmu Jidal al-Qur'an, ilmu yang menjelaskan bentuk-bentuk debat atau bantahan al-Quran terhadap orang-orang kafir, Quraish, Yahudi, dan sebagainya.

16. Ilmu Adab al-Tilawah al-Qur'an, ilmu yang menjelaskan adab, tatakrama yang harus digunakan ketika membaca al-Quran.

Untuk memahami salah satu dari 16 ilmu memahami al-Quran itu tidaklah mudah. Karena pertama-tama, seseorang juga harus menguasai ilmu gramatikal Arab (nahwu dan saraf). Jika demikian, seseorang yang berusaha menafsirkan al-Quran tanpa memahami keenam belas ilmu di atas, maka dapat dipastikan penafsirannya tidak benar. Dari sini pula, sangat jelas bahwa kita tidak cukup memahami al-Quran dari terjemah al-Quran. 


\section{Bayan Nabawi}

Bayan nabawi adalah penjelasan Nabi baik berupa ucapan Nabi, perbuatan Nabi, diamnya Nabi atas suatu peristiwa, maupun sifat-sifat dan hal ihwal Nabi, yang terutama berkaitan dengan hukum syara'.

Perlu diketahui jumlah hadis Nabi sangat banyak, dan masing-masing ulama hadis memiliki hafalan hadis yang berbeda-beda, bahkan klaim kesahihan hadis pun tidak sama satu dengan yang lain. Ada enam kitab hadis yang sangat terkenal yang disebut dengan Kutub al-Sittah (kitab-kitab yang enam), yaitu; 1) Șaḥịh al-Bukhari yang dihimpun oleh Imam Bukhari, 2) Șaḥị̣ al-Muslim yang dihimpun oleh Imam muslim, 3) Sunan an-Nasā'i yang dihimpun oleh Imam Nasai, 4) Sunan Abu Dawud yang dihimpun oleh Imam Abu Dawud, 5) Sunan at-Tirmiži yang dihimpun oleh Imam Tirmiži, dan 6) Sunan ibnu Mājah yang dihimpun oleh Imam Ibnu Majah.

Dan masing-masing kitab tersebut memuat jumlah hadis yang berbedabeda. Menurut penghitungan Ibnu Shalah, kitab Șaḥị al-Bukhari menghimpun 7275 hadis dengan dengan pengulangan. Jika tanpa pengulangan berjumlah 4000 hadis. Sedangkan Șaḥị̣ al-Muslim, tanpa pengulangan, berjumlah sekitar 4000 hadis. Sementara Imam Nasa'i menghimpun sekitar 5200 hadis dalam kitab Sunan an-Nasāii.

Imam Bukhari mengklaim bahwa ia tidak memasukkan hadis ke dalam kitabnya kecuali yang sahih. Klaim serupa juga dikemukakan oleh Imam muslim. Keduanya menghafal lebih dari 100.000 hadis, namun tidak semuanya dikategorikan sebagai hadis sahih.

Ada dua komponen dalam mempelajari hadis, yakni sanad dan matan. Sanad adalah mata rantai orang yang meriwayatkan suatu hadis sampai pada sumber yang pertama, yakni Nabi Muhammad. Misalnya, “Dikabarkan kepada kami oleh Malik yang menerimanya dari nafi yang menerimanya dari Abdullah ibnu Umar bahwa Rasulullah Saw. bersabda ......"

Sementara matan adalah kalimat atau perkataan yang disebut di bagian akhir sanad, "....... Tidak sempurna iman seseorang di antara kalian sehingga ia mencintai untuk saudaranya apa yang ia cintai untuk dirinya sendiri”. 
Dalam ilmu hadis ('ulūm al-ḥadis), hadis dapat diklasifikasikan berdasarkan pada tiga kriteria, yang masing-masing memiliki beberapa jenis di dalamnya. Berikut penjelasannya:

\section{a. Berdasarkan Keutuhan Rantai Sanad}

Berdasarkan keutuhan rantai sanad, hadis digolongkan ke dalam 6 kategori;

1. Hadis Mursal: Merupakan hadis yang penutur satunya tidak dijumpai secara langsung.

2. Hadis Munqați: Merupakan hadis yang putus pada salah satu atau dua penutur.

3. Hadis Mu'dal: Merupakan hadis yang terputus pada dua generasi penutur secara berturut-turut.

4. Hadis Mu'allaq: Merupakan hadis yang terputus sebanyak 5 penutur, dimulai dari penutur pertama secara berturut-turut.

5. Hadis Mudallas: Merupakan hadis yang tidak tegas disampaikan secara langsung kepada penutur.

6. Hadis Musnad: Merupakan hadis yang penuturnya paling jelas dan tidak terpotong sama sekali.

\section{b. Berdasarkan Jumlah Penutur}

Jumlah yang meriwayatkan suatu hadis bermacam-macam. Pada saat tertentu, satu hadis bisa diriwayatkan oleh 5 orang, misalnya, dan pada saat yang lain diriwayatkan oleh 6 orang. Karena itulah, dalam soal jumlah penutur, hadis dikategorikan ke dalam 2 bagian;

1. Hadis Mutawātir: Merupakan hadis yang diriwayatkan oleh sekelompok orang yang sudah sepakat untuk saling mempercayai.

2. Hadis Ahad:Merupakan hadis yang diriwayatkan oleh sekelompok orang yang belum mencapai tingkatan mutawātir. hadis Ahad sendiri dapat dikelompokkan ke dalam tiga macam hadis yaitu gharib, 'aziz, dan masyhur. 


\section{c. Berdasarkan Keaslihan hadis}

Sementara itu, berdasarkan kesahihan suatu hadis dapat diklasifikasikan ke dalam empat macam;

1. Hadis Șaḥiḥ: Merupakan hadis yang sanadnya bersambung, paling diakui tingkat keasliannya dan paling banyak diterima oleh kelompok ulama.

2. Hadis Hasan: Merupakan hadis yang sanadnya bersambung, namun diriwayatkan oleh rawi yang tidak sempurna ingatannya.

3. Hadis Dha'if: Merupakan hadis yang sanadnya tidak bersambung atau pun diriwayatkan oleh rawi yang tidak kuat ingatannya/tidak adil.

4. Hadis Maudhû': Merupakan hadis yang dicurigai palsu ataupun karangan manusia.

Masing-masing klasifikasi di atas memiliki penjabaran tersendiri yang lebih detail, baik terkait dengan ciri-cirinya, maupun klasifikasi yang lebih detail di dalamnya. Hal tersebut menyadarkan kita bahwa mengambil hadis secara serampangan bisa berbahaya, karena bisa saja hadis yang dinukil justru termasuk hadis palsu.

Karena itulah, para ulama ahli hadis menyusun ilmu untuk memahami hadis dengan benar. Salah satunya adalah alm. KH. Ali Mustafa Ya'qub. Dalam salah satu bukunya, ia mengatakan:

$$
\begin{aligned}
& \text { وتنحصر دراسات الحديث النبوي في العصر الحاضر على ثلاثة أمور : } \\
& \text { الأول ما يتعلق بمصطلح الحديث بما في ذلك الدفاع عن الحديث ضد } \\
& \text { منكري الحديث والمستشرقين. والثاني ما يتعلق بطرق تخريج الحديث } \\
& \text { وونقد المتون والأسانيد. والثالث ما يتعلق بفهم الحلديث النبوي }
\end{aligned}
$$


Kajian hadis pada masa sekarang terbagi menjadi tiga bahasan. Pertama, berkaitan dengan Ilmu musțalah al-ḥadis, termasuk untuk mempertahankan hadis dari serangan orang-orang yang menolak hadis dan para orientalis. Kedua, berkaitan dengan metode takhrij serta kritik matan dan sanad hadis. Ketiga, bahasan yang berkaitan dengan metode pemahaman hadis.

Dengan demikian, ada tiga ilmu mendasar dalam memahami hadis Nabi. Pertama, ilmu mustalah al-ḥadis. Mahmud Ṭahhan dalam karyanya Taisir Mustalahil al-Hadis memberikan definisi sebagai berikut:

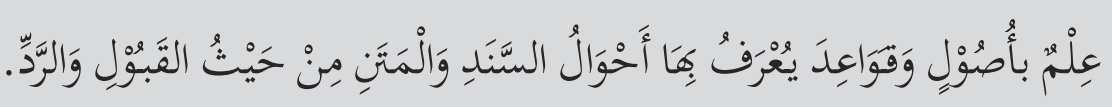

Yaitu ilmu yang mengkaji tentang kaidah-kaidah terkait sanad (silsilah) dan matan (redaksi) sebuah hadis untuk menentukan apakah suatu hadis valid atau tidak.

Dengan menguasai ilmu ini, seseorang dapat menentukan dan membedakan hadis sahih, hasan dan dha'if, serta apa yang disebut dengan mutawātir lafżi dan mutawātir ma'nawi, misalnya. Ilmu ini pertama kali dicetuskan oleh Abū Muḥammad al-Ḥasan ibn 'Abd al-Raḥmān ibn Khallād al-Rāmahurmuzī (360 H) lewat karyanya Al-Muhaddis al-Fasil Bainar ar-Rawi wa al-Wa'i.

Kedua, Ilmu Takhrij dan Dirāsah Sanad, yaitu ilmu yang berisi tatacara mengidentifikasi sebuah teks; apakah benar ia berstatus sebagai hadis Nabi atau bukan. Mahmud Tahhan mendefinisikan takhrij hadis sebagai;

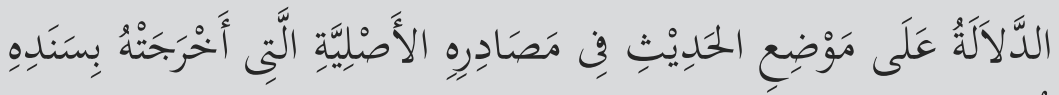

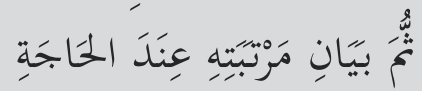


Penunjukkan terhadap tempat hadis dan sumber aslinya yang dijelaskan sanadnya dan martabatnya sesuai dengan keperluan.

Dengan menguasai ilmu ini, seseorang dapat mengetahui asal usul hadis yang pada gilirannya dapat mengetahui apakah sanad dari hadis tersebut tersambung secara valid sampai Nabi Muhammad atau tidak. Ada banyak metode untuk melakukan takhrij hadis ini.

Ketiga, yaitu ilmu yang berisi tentang cara serta kaidah-kaidah dalam memahami teks hadis seperti kaidah tidak semua hadis sahih langsung diamalkan, tidak semua hadis dha'if langsung ditolak, kaidah membedakan antara hadis yang mengandung syariat dan hadis yang hanya sebatas budaya lokal Arab semata dan lain sebagainya.

Dari penjelasan ini, sangat jelas bahwa memahami hadis juga tidak mudah, memerlukan beragam perangkat ilmu di dalamnya. Sehingga, seseorang tidak bisa asal comot suatu hadis tanpa mengetahui kualitas dari hadis tersebut. Demikian pula, kita tidak bisa serta merta memahami hadis hanya dari terjemahan hadis tersebut, apalagi seketika langsung mengaplikasikannya tanpa memahami konteks hadis dan konteks lokal di mana kita berada. 


\section{Bayan 'Aqli}

Untuk memahami kedua sumber Islam tersebut, al-Quran dan hadis, maka secara pasti kita memerlukan penggunaan akal pikiran. Akal pikiran di sini bukan berarti hanya akal pikiran kita saat ini, tetapi juga akal pikiran para sahabat serta ulama-ulama terdahulu yang telah bersepakat tentang suatu hukum, yang disebut dengan ijma'. Termasuk juga dalam bayan 'aqli di sini adalah penggunaan qiyas kasus hukum yang baru muncul dengan kasus yang sudah ditentukan hukumnya. Karena itu, pada bagian ini, penulis akan mengulas keduanya.

\section{a. Ijma'}

Secara istilah ijma' didefinisikan oleh Dr. Abdul Karim Zaidan sebagai:

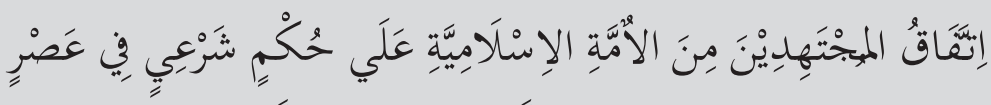

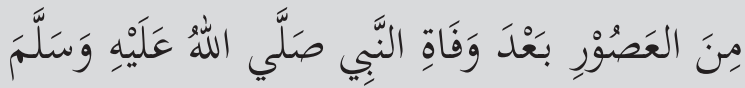

Kesepakatan ulama mujtahid dari umat Islam tentang hukum syara' dalam suatu masa setelah wafatnya Nabi Muhammad.

Definisi di atas menyiratkan bahwa kesepakatan ulama non-mujtahid tidak dikategorikan sebagai ijma'. Misalnya, kesepakatan segelintir ustaz tentang suatu hukum bukanlah ijma'. Karena syarat utama dari ijma' adalah dilakukan oleh mujtahid. Mujtahid adalah:

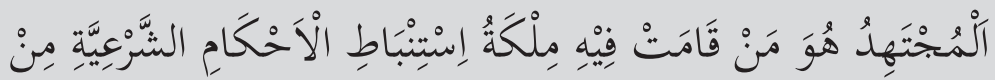

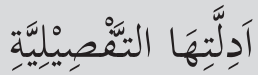

Mujtahid adalah orang yang mempunyai kemampuan yang menyatu dalam jiwanya untuk melahirkan hukum syara' dari dalil-dalil terperinci. 
Hal ini juga menyiratkan masalah yang disepakati berkaitan dengan konteks hukum syara', seperti wajib, haram, sunnah, makruh dan sebagainya. Sehingga kesepakatan-kesepakatan di luar hukum syarat tidak bisa disebut dengan ijma', misalnya kesepakatan di bidang kedokteran, olahraga, seni dan sebagainya.

Sayyid Muhammad bin Alawi al-Maliki al-Hasani membagi ijma' ke dalam tiga bagian: 1) ljma' Qauli, yaitu kesepakatan yang dideklarasikan secara verbal, misalnya mereka berkata bahwa hal ini haram, wajib, dst. 2) ljma' Fi'li yaitu kesepakatan dalam bidang perbuatan, misalnya para mujtahid melakukan pekerjaan yang menunjukkan kebolehan pekerjaan tersebut. 3) ljma' Sukuti, ijma' di mana sebagian mujtahid menyampaikan pendapat dan sebagian mujtahid melakukan suatu pekerjaan, yang pendapat dan pekerjaan mujtahid tersebut menyebar kepada mujtahid yang lain sementara mujtahid yang lain diam dan tidak mengingkari setelah melakukan kajian dan analisis mendalam dalam waktu yang cukup (Asmani, 2018)

Para ulama ușūl figh mengemukakan lima rukun ijma', yaitu:

Yang terlibat dalam pembahasan hukum syara melalui ijma' tersebut adalah seluruh mujtahid. Apabila ada di antara mujtahid yang tidak setuju, sekalipun jumlahnya kecil, maka hukum yang dihasilkan itu tidak dinamakan hukum ijma'.

1. Mujtahid yang terlibat dalam pembahasan hukum itu adalah seluruh mujtahid yang ada pada masa tersebut dari berbagai belahan dunia Islam.

2. Kesepakatan itu diawali setelah masing-masing mujtahid mengemukakan pandangannya.

3. Hukum yang disepakati itu adalah hukum syara' yang bersifat aktual dan tidak ada hukumnya secara rinci dalam al-Quran.

4. Sandaran hukum ijma' tersebut haruslah al-Quran dan atau hadis Rasulullah Saw. 


\section{b. Qiyās}

Qiyās atau analogi didefinisikan oleh Fakhruddin ar-Razi, sebagai berikut:

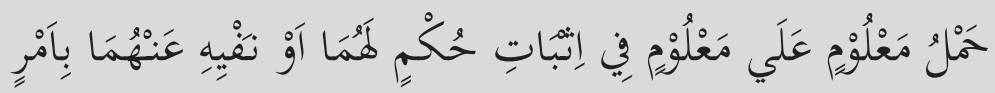

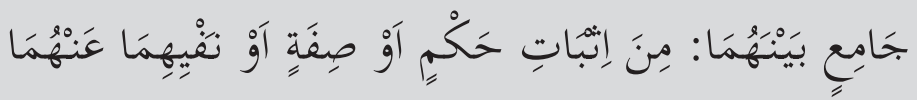

Qiyās adalah menyamakan sesuatu yang diketahui kepada sesuatu yang diketahui dalam penetapan hukum keduanya atau menafikan hukum keduanya karena ada sesuatu yang menggabungkan keduanya, baik dalam konteks menetapkan hukum atau sifat atau menafikan keduanya

Salah satu contoh qiyās adalah yang diberikan oleh Abdul Wahhab Khallaf soal keharaman meminum perasan kurma yang memabukkan dengan dianalogikan kepada surah al-Maidah ayat 90 :

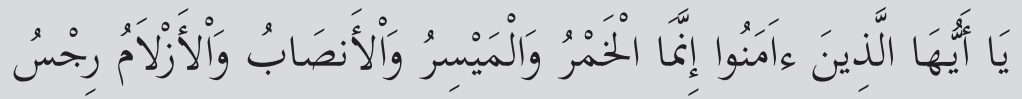

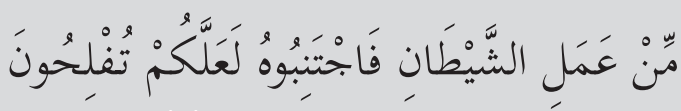

Hai orang-orang yang beriman, sesungguhnya (meminum) khamar, berjudi, (berkorban untuk) berhala, mengundi nasib dengan panah, adalah perbuatan keji termasuk perbuatan syaitan. Maka jauhilah perbuatanperbuatan itu agar kamu mendapat keberuntungan. 
Menurut Abdul Wahhab Khallaf, ada empat rukun qiyās:

1. Asal (آصَّل ) yaitu: sesuatu yang status hukumnya ada pada nash, baik al-Quran maupun hadis. Asal ini dinamakan : المَقِيْسنُ عَعَيْْهِ

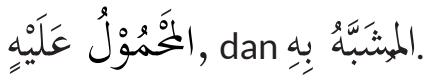

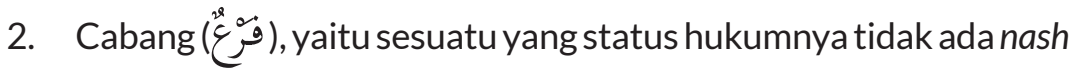
dan status hukumnya ingin disamakan dengan status hukum asal.

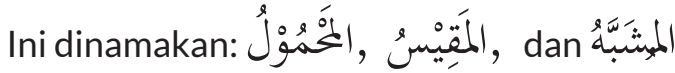

3. Hukum asal (حُكُُْ الأصْلِ), yaitu hukum syara' yang menjadi kandungan nash.

4. Illat (عِلَّلَّ) yaitu: sifat yang menjadi dasar hukum asal dan dasar adanya hukum dalam cabang.

Penjelasan keduanya secara lebih detail dapat dijumlah di sejumlah kitab uṣūl fiqh, seperti uṣūl fiqh karya Abdul Wahab Khallaf, Abu Zahro, dan lain sebagainya. 



\section{BAB TIGA}

\section{MENJAWAB POKOK MASALAH AKIDAH}

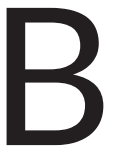

agian ini secara khusus membahas hal-hal yang seringkali diduga akan meluluhlantakkan akidah umat Islam. Tentunya, tidak mengulas seluruh bagian akidah, hanya beberapa bagian yang menjadi perbincangan hangat di kalangan masyarakat. Karena itulah, bagian ini mengulas lima pokok masalah: 1) Bid'ah sebagai sumber kerusakan Islam, 2) Menjadi Firqotun Nājiyah, 3) Menegakkan syariat Islam, 4) Pengertian dan macam-macam kufur, dan 5) Larangan mengafirkan sesama muslim.

\section{Bid'ah Sumber Kerusakan Islam?}

Belakangan ini, sebagian umat Islam dilanda kekhawatiran tentang apakah Islamnya sama seperti Islam yang diajarkan dan dipraktikkan oleh $\mathrm{Nabi}$ Muhammad Saw. Pertanyaan-pertanyaan yang muncul pun seputar; 
apakah ibadah yang saya lakukan juga dipraktikkan oleh Nabi? Apakah doa yang dipanjatkan juga dibaca oleh Nabi? Apakah tindakan seperti ini dilakukan oleh Nabi? Adakah perintah Allah akan sikap seperti ini?

Kekhawatiran semacam ini sangat baik, karena akan membawa seseorang untuk mempelajari Islam dengan sungguh-sungguh, dengan melacak langsung sumber utama; al-Quran dan hadis. Dan memang seharusnya, setiap muslim mengerti bahwa pikiran dan tindakannya tidak boleh bertentangan dengan syariat Islam.

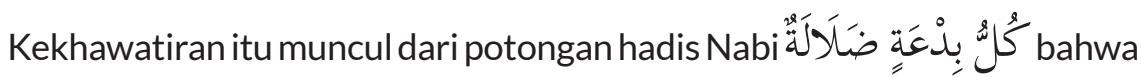
setiap bid'ah adalah kesesatan. Karena potongan hadis inilah, umat Islam menjadi ragu dan was-was, khawatir terjerumus kepada kesesatan.

Disebut potongan hadis, karena hadis yang sangat masyhur itu sebenarnya memiliki redaksi yang cukup panjang yang diriwayatkan oleh muslim Abu Dawud, Ibnu Majah, dan al-Tirmiżi, sebagai berikut:

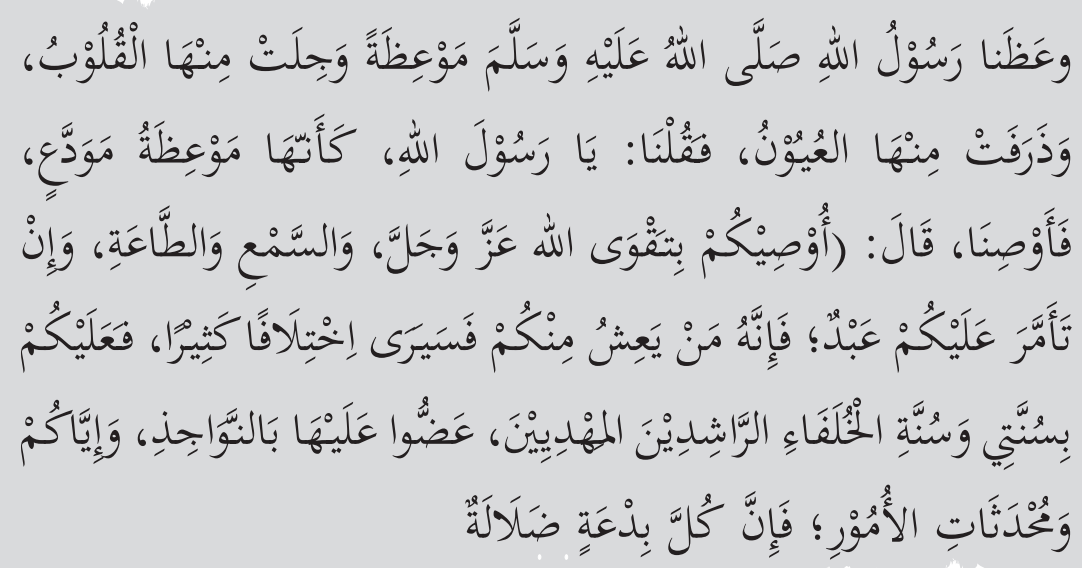

"Rasūlullāh memberi kami nasihat yang membuat hati kami semua bergetar. Dan mengalir air mata. Lalu kami berkata, "Ini seperti nasihat perpisahan wahai Rasulullah, berilah kami wasiat!" Beliau bersabda, "aku berwasiat kepada kalian 
agar selalu takut kepada Allah, serta selalu mendengarkan dan taat kepada pemimpin. Walaupun nanti yang memimpin kalian adalah seorang budak hitam dari Habasyah. Karena siapapun di antara kalian yang panjang umur, pasti akan menjumpai banyak perselisihan. Tetaplah kalian berpegang kepada sunnahku dan sunnah para khalifah yang mendapat bimbingan sesudahku. Peganglah erat-erat sunah itu. Dan berhati-hatilah terhadap perkara yang baru. Karena setiap bid'ah adalah kesesatan."

Akibat terpotongnya hadis tersebut, pesan lain seperti perintah untuk bertakwa, mendengarkan dan taat kepada pemimpin, perintah untuk berpegang teguh kepada sunah $\mathrm{Nabi}$, seringkali tidak tersampaikan kepada umat. Yang sampai ke telinga masyarakat awam hanyalah kehati-hatian terhadap perkara baru.

Para ulama tentu saja setuju ihwal kesahihan hadis tersebut. Namun, untuk menentukan mana-mana "hal baru" yang menjurus kepada kesesatan tersebut, bukanlah perkara mudah. Imam al-Nawawi dan Imam al-Taftazani berpendapat bahwa yang dimaksud dengan bid'ah adalah setiap perbuatan yang tidak dapat dikembalikan (dirujuk) dalilnya. Imam al-Nawawi di dalam penjelasan kitab al-Arba'in berpendapat bahwa bid'ah adalah perbuatan menambah bagian dari rukun Islam yang lima. Sedangkan alTaftazani berpendapat bahwa bid'ah adalah perbuatan yang tidak dapat dikembalikan kepada dalil syariat, baik berupa al-Quran dan Sunah, serta ijma' dan qiyās yang dirumuskan melalui proses ijtihad.

Penekanan kepada prinsip "tidak bertentangan syariat Islam" ini penting, mengingat ada banyak persoalan baru yang belum pernah dilakukan oleh Nabi dan sahabat tetapi tidak bertentangan syariat Islam. Misalnya, bukankah kegiatan bermain media sosial, naik mobil, naik pesawat dan lain sebagainya tidak pernah dilakukan oleh Nabi, lalu apakah dikategorikan sebagai bid'ah yang menyesatkan tersebut?

Atas hal tersebut, Imam Syafii membagi bid'ah ke dalam dua kategori; bid'ah terpuji (mahmūdah) dan bid'ah tercela (madmūmah). Ini artinya, ada banyak perilaku baik yang belum dipraktikkan secara langsung oleh 
Nabi tetapi tidak bertentangan dengan syariat Islam. Tentu saja, ada pula bid'ah tercela yang belum muncul pada masa Nabi tetapi di era sekarang dipraktikkan oleh umat Islam.

Singkatnya, penentuan apakah sebuah perilaku atau tindakan itu termasuk kategori bid'ah tercela yang mengandung kesesatan atau tidak, perlu ditelaah secara mendalam dengan mengkaji teks-teks (nuṣūṣ) yang dilakukan oleh para ahli (ulama).

Mari kita cek beberapa perilaku atau kegiatan yang dilakukan oleh masyarakat yang kerapkali dituding bid'ah yang pada tahap berikutnya dituduh mengandung kesesatan.

1. Mengadakan tahlil bagi orang yang sudah wafat. Tradisi tahlil adalah kegiatan yang lazim dilakukan oleh generasi salaf yang saleh (salafaṣ-ṣ. olih), sebagaimana yang diriwayatkan oleh Imam Thowus ibn Kaysan al-Yamani, seorang ulama tābi'ut tābi'in. Mengutip pendapat Imam Thowus al-Hafiż as-Suyūți di dalam al-Hawi li al-Fatāwa, mengatakan: "Sungguh mayat itu akan terus ditanya di alam kuburnya selama tujuh hari. Dan dulu para sahabat sering bersedekah memberi makanan selama waktu tersebut." Keterangan ini terkonfirmasi dengan kebiasaan masyarakat Mekah, yaitu memberi makanan pada hari ketujuh kematian seseorang. Mereka menamainya dengan lailah al'Asya' li al-Walidayn, "Malam memberi makan atas nama kedua orang tua."

2. Apakah memperingati maulid Nabi adalah perkara bid'ah yang sesat? Benar bahwa Nabi tidak pernah mengadakan maulid Nabi. Namun bukan berarti pelaksanaan maulid Nabi itu tercela. Karena peringatan maulid Nabi adalah ekspresi cinta kepada Nabi; untuk mengenang, mempelajari dan meneladani perjuangan dan sosok Nabi Muhammad Saw. Karena itulah, Syekh Dr. Muhammad Sa'id Ramadhan al-Buthi yang wafat tahun 2013 silam mengatakan bahwa tradisi memperingati maulid Nabi merupakan perbuatan yang dianggap sebagai maṣlaḥah al-mursalah yaitu kebaikan yang tidak disebut di dalam al-Quran dan juga sunah. Lebih jauh, pemberian harakat dan tanda titik pada 
al-Quran baru dilakukan setelah Nabi Muhammad Saw. wafat, namun tentu saja, hal tersebut bukan perkara bid'ah.

Singkatnya, penentuan apakah suatu perilaku atau tradisi masuk kategori bid'ah atau tidak membutuhkan kajian yang cukup mendalam, tidak bisa dilakukan secara sembrono. Karena tidak semua yang tidak dilakukan Nabi menjadi terlarang untuk dilakukan. Dan tidak semua yang tidak dilarang oleh Nabi, menjadi boleh untuk dilakukan.

Yang jelas, jika penambahan hal-hal baru tersebut terkait dengan akidah dan ibadah yang bertentangan dengan syariat Islam, maka hadis "setiap bid'ah adalah kesesatan" dapat dibelakukan. Contohnya;

1. Menambah atau mengurangi rakaat pada salat fardu yang telah ditetapkan, subuh menjadi 3 atau 1 rakat.

2. Memperpanjang waktu puasa bulan Ramadan hingga melewati waktu iftar, sampai tengah malam, misalnya.

3. Melakukan haji di gunung atau gua.

Sementara itu, praktik-praktik baik yang dilakukan masyarakat yang tidak bertentangan dengan syariat Islam, maka dianjurkan untuk dilakukan. Namun, untuk mengetahui apakah perilaku atau kebiasaan tersebut bertentangan dengan syariat Islam, sebaiknya bertanya kepada para penerus Nabi; ulama.

Jika demikian, tak setiap hal yang baru harus ditolak dan menjadi sumber kerusakan Islam. Islam justru sangat menghargai inovasi dan kreativitas sejauh tidak bertentangan dengan syariat. Dalam berdakwah misalnya, seorang ustaz bisa saja menggunakan media yang tidak pernah digunakan oleh Nabi, seperti Youtube, Facebook, Twitter dan Instagram sebagai kreaktivitas dan inovasi dalam berdakwah. 


\section{Menjadi Firqah An-Nājiyah}

Semua umat Islam ingin menjadi kelompok yang selamat (al-firqah annājiyah). Tidak ada seorang muslim yang ingin tidak selamat, baik di dunia maupun di akhirat. Karena itulah, umat Islam dianjurkan membaca doa, yang termaktub dalam surah al-Baqarah ayat 201:

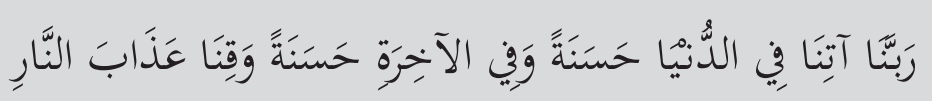

Ya Allah, berikanlah kepada kami kebaikan di dunia, berikan pula kebaikan di akhirat dan lindungilah kami dari siksa neraka. [QS al-Baqarah: 201]

Istilah al-firqah al-nājiyah popular pada abad ke-2 Hijriah, ketika umat Islam dihadapkan pada perdebatan tentang konsep ketuhanan (teologis). Istilah tersebut bermula dari hadis $\mathrm{Nabi}$,

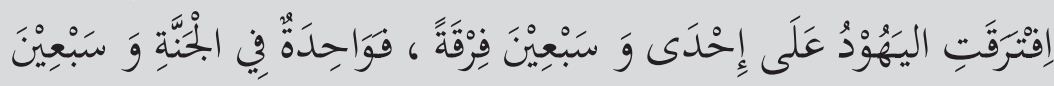

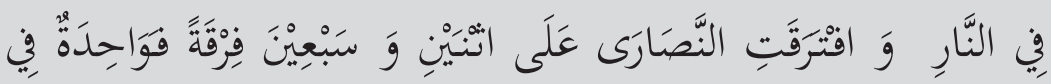

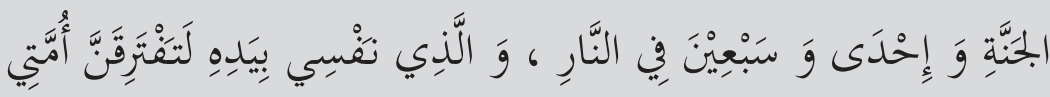

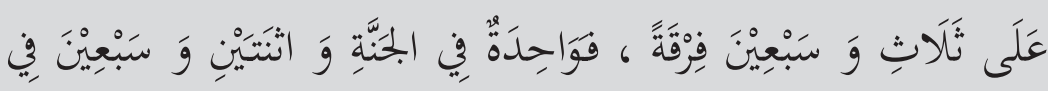

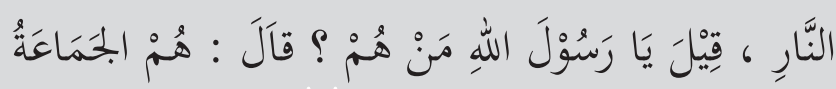

"Yahudi telah berpecah-belah menjadi 71 golongan, maka satu di surga dan tujuh puluh di neraka. Dan Nashara telah berpecah belah menjadi 72 golongan, maka satu di surga dan tujuh puluh satu di neraka. Dan demi yang jiwaku di tangan-Nya, sungguh umatku akan berpecah belah menjadi 73 golongan, maka 
satu di surga dan tujuh puluh dua di neraka, dikatakan, "Wahai Rasul Allah siapa mereka itu?", beliau berkata: "mereka adalah al-jama'ah."' (HR Ahmad)

Muhammad Jamil Zainu dalam kitab Minhāj al-Firqah al-nājiyah wa al-Thāifat al-Manșurat menyebutkan 12 ciri kelompok yang selamat itu, yang salah satunya adalah pengingkaran terhadap perundang-undangan yang dibuat oleh manusia. Dalam konteks Indonesia, mereka mengingkari Pancasila dan Undang-Undang Dasar; karena dibuat oleh manusia. Pemaknaan seperti ini bukan saja salah tetapi juga berbahaya bagi kelangsungan Negara Kesatuan Republik Indonesia (NKRI). Melalui pemaknaan seperti ini, beberapa kelompok hendak menolak Pancasila dan ingin menjadikan syariat Islam sebagai undang-undang yang berlaku di Indonesia.

Pemaknaan seperti yang dikenalkan oleh Muhammad Jamil Zainu itu jelas bertentangan dengan syariat Islam itu sendiri. Pasalnya, hadis di atas menegaskan bahwa kelompok yang selamat itu adalah “Jemaah". Lalu, siapa yang disebut jemaah tersebut? Mari kita rujuk sejumlah ayat al-Quran, perihal perintah untuk berjamaah, bersatu serta larangan bercerai berai;

1. Surah Āli Imrān ayat 103:

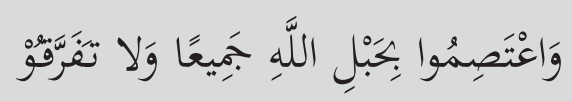

Dan berpeganglah kamu semuanya kepada tali (agama) Allah, dan janganlah kamu bercerai berai, ..." [QS Âli Imrān ayat 103]

2. Surah Āli Imrān ayat 105:

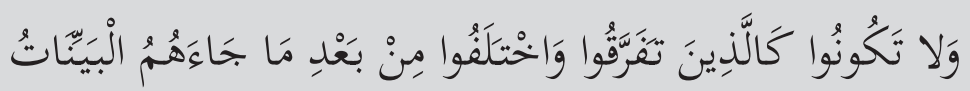

"Dan janganlah kamu menyerupai orang-orang yang bercerai-berai dan berselisih sesudah datang keterangan yang jelas kepada mereka...." [QS Āli Imrān ayat 105] 
Dua ayat di atas sangat jelas berisi perintah untuk bersatu dan larangan untuk terpecah belah. Dalam hadis Nabi juga disebutkan:

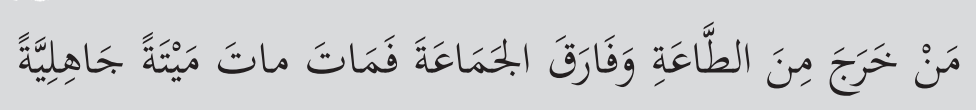

"Barangsiapa keluar dari ketaatan (pada amir) dan memisahkan diri (berpecah) dari al-Jama'ah kemudian mati, maka mati dalam keadaan mati Jahiliah." [Muslim dari Abu Hurairah]

Karena itulah, penambahan kriteria "ingkar terhadap undang-undang yang dibuat oleh manusia" seperti yang dilakukan oleh Muhammad Jamil Zainu tidak benar. Mengapa demikian? Karena undang-undang yang dibuat oleh manusia seperti Pancasila dan UUD untuk mengatur kehidupan warga negara yang majemuk, dan tidak ada peraturan yang diundangkan bertentangan dengan syariat Islam. Penjelasan lebih detail soal akan diulas di bab berikutnya: Menegakkan Syariat Islam.

Imam asy-Syatibi merangkum pendapat para ulama tentang siapa yang disebut dengan jama'ah dalam hadis di atas, kepada lima pendapat:

1. As-Sawādu al-A'ẓam (السَّوَادُ الأَعْظَمْ (الَّ), yaitu kelompok terbesar dari kelompok umat Islam. Dengan kata lain, mereka adalah kelompok Islam yang berpegang teguh kepada syariat Islam dengan benar. Pendapat ini dikemukakan oleh Abu Mas'ud al-Anșari dan Ibnu Mas'ud.

2. Jamaah para imam mujtahid, khususnya dari kelompok As-Sawādu al-A'żam, seperti Abu Bakar, Umar, dst. Maka barangsiapa yang keluar dari apa yang telah disepakti oleh para imam mujtahid, maka matinya dalam keadaan Jahiliah. Ini sesuai dengan hadis Nabi bahwa “Sesungguhnya Allah tidak akan mengumpulkan umatku dalam keadaan kesesatan". Pendapat ini dikemukakan oleh Abdullah bin al-Mubarak, Ishak bin Rahawaihi, dan sejumlah ulama salaf lainnya. 
3. Para sahabat Nabi secara khusus, sebagaimana dikemukakan oleh 'Umar bin Abdil Aziz. Argumentasi kelompok ini memandang bahwa para sahabat berhasil menegakkan Islam secara keseluruhan, sehingga menyelisihi pendapat-pendapat mereka dianggap sebagai kesesatan. Dalam konteks inilah, hadis nabi sebagaimana yang diriwayatkan oleh Imam Malik dan At-Tirmiẓi, مَا أَنَا عَلَيْيْ وَأَصْحَابِ "apa yang aku dan sahabatku di atasnya".

4. Jama'ah Ahlal-Islam, yakni sekumpulan ulama yang memiliki kepakaran di bidang Islam, sehingga ketika mereka duduk dan mengeluarkan kesepakatan maka seluruh umat Islam wajib menaatinya. Dalam konteks ini, Imam Syafii berkata al-Jama'ah tidak mungkin di dalamnya lalai dari makna al-Quran dan sunah, tidak pula qiyas. Kelalaian hanya terjadi pada firqah (sempalan).

5. Jemaah kaum muslim jika bersepakat pada amir (pemimpin), artinya kesepakatan-kesepakatan umat Islam dalam suatu pemimpin baik dalam skala negara maupun lintas negara, sehingga jika ada orang atau kelompok menyelisihi pendapatnya diperkenankan untuk ditindak dengan tegas.

Singkatnya, dari kelima pendapat di atas, tampak sekali bahwa Islam menjunjung tinggi persatuan, anti perpecahan, dengan tetap mengacu kepada al-Quran, sunah dan pendapat ulama salaf.

Dalam konteks Indonesia, di mana terdapat keragaman agama, suku, etnis, ras dan bahasa, Islam tetap menjunjung tinggi persatuan dalam bingkai Negara Kesatuan Republik Indonesia. Terlebih, ajaran-ajaran terdahulu sebagaimana yang dipercayai oleh para ahli kitab memiliki banyak kesamaan prinsip dengan Islam, sebagaimana yang ditegaskan oleh Allah dalam surah Asy-Syura ayat 13 dan surah Āli Imrān ayat 64: 


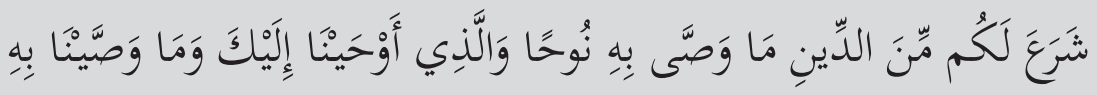

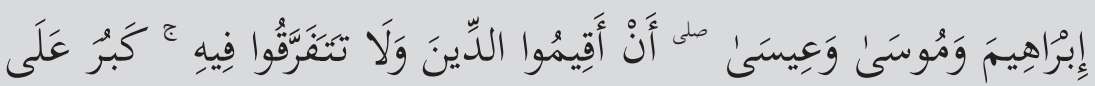

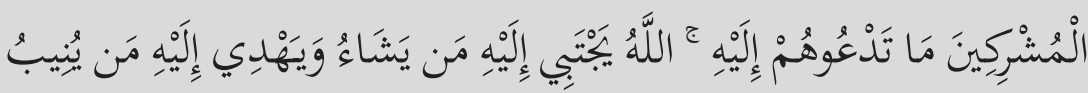

Dia telah mensyariatkan bagi kamu tentang agama apa yang telah diwasiatkanNya kepada Nuh dan apa yang telah kami wahyukan kepadamu dan apa yang telah kami wasiatkan kepada Ibrahim, Musa dan Isa yaitu: Tegakkanlah agama dan janganlah kamu berpecah belah tentangnya. Amat berat bagi orang-orang musyrik agama yang kamu seru mereka kepadanya. Allah menarik kepada agama itu orang yang dikehendaki-Nya dan memberi petunjuk kepada (agama)Nya orang yang kembali (kepada-Nya). [QS asy-Syura: 13]

Pertalian ide "kelompok yang selamat" itu kembali ditegaskan di dalam surah Âli Imrān ayat 64:

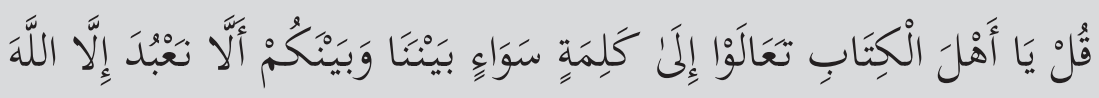

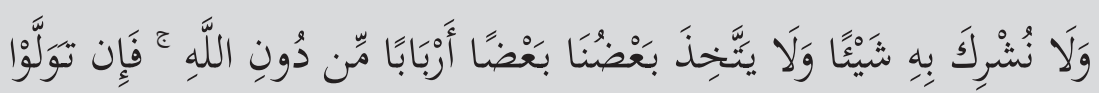

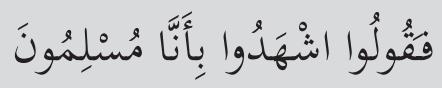

Katakanlah: "Hai Ahli Kitab, marilah (berpegang) kepada suatu kalimat (ketetapan) yang tidak ada perselisihan antara kami dan kamu, bahwa tidak kita sembah kecuali Allah dan tidak kita persekutukan Dia dengan sesuatu pun dan tidak (pula) sebagian kita menjadikan sebagian yang lain sebagai Tuhan selain Allah". Jika mereka berpaling maka katakanlah kepada mereka: "Saksikanlah, bahwa kami adalah orang-orang yang berserah diri (kepada Allah)" 
Sampai di sini, kita menyimpulkan bahwa ide "kelompok yang selamat" menurut ajaran Islam, adalah kelompok yang mengamalkan prinsip-prinsip ajaran Islam, sebagaimana yang diajarkan oleh Nabi Muhammad. Prinsipprinsip itu tidak saja berkisar pada persoalan tata cara peribadatan, tetapi juga mencakup etika dan moral di dalam berinteraksi di antara sesama manusia. Dalam kaitan itu, di dalam ajaran Islam, sangat ditekankan sikap untuk menghormati perbedaan, termasuk di dalam perbedaan keyakinan. 


\section{Pengertian dan Macam-Macam Kafir}

Sebelum kita mengetahui makna dari kata kafir, terlebih dahulu kita harus mengetahui makna kata kufr (kekufuran). Dalam bahasa Arab arti kata kufr adalah tutup (as-satr wa at-taghthiyyah). Sedangkan kafir adalah isim fa'il dari kufr. Karenanya, malam dinamai kafir sebab ia menutupi sesuatu dengan kegelapannya.

Al-Khazin dalam Tafsir al-Khazin mengatakan:

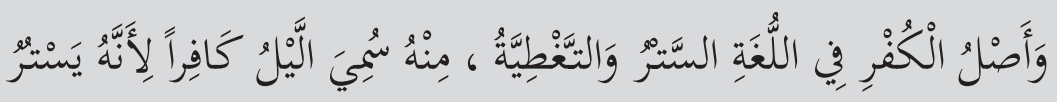

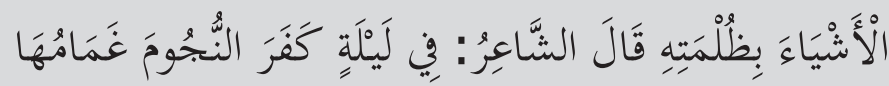

"Asal kata kufr secara bahasa maknanya adalah tutup. Dari makna ini maka malam disebut kafir (yang menutipi) karena menutupi segala sesuatu dengan kegelapannya. Seorang penyair berkata, 'di suatu malam yang kegelapannya menutupi bintang-gemintang'"

Sedangkan penggunaan kata kufr dalam al-Quran dengan segala bentuk turunannya disebut sebanyak 525 kali yang tersebar di 73 surat dari total 114 surat yang ada dalam al-Quran. Jika merujuk pada ayat-ayat tersebut, pengertian kufr tidaklah tunggal. Abu al-Abbās Muqri` dalam kitab al-Lubab fi Ulum al-Kitab menyebut empat jenis makna kufr dalam al-Quran. Pertama, dalam pengertian "menutupi ketauhidan" sebagaimana firman Allah Swt.,

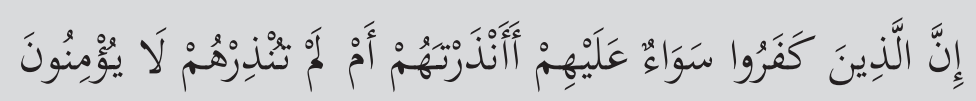

"Sesungguhnya orang-orang kafir, sama saja bagi mereka, engkau (Muhammad) beri peringatan atau tidak engkau beri peringatan, mereka tidak akan beriman". [QS al-Baqarah: 6] 
Selain ayat ini, sejumlah ayat lain juga menunjukkan makna serupa, seperti pada surah al-Baqarah ayat 108 :

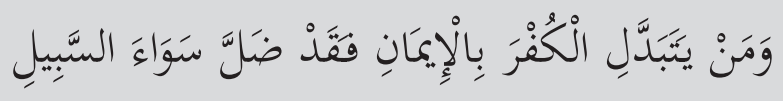

Barangsiapa yang menukar keimanan dengan kekafiran, maka sungguh orang itu tersesat di jalan yang lurus. [QS al-Baqarah: 108]

Dalam surah at-Taubah ayat 23 juga disebutkan disebutkan:

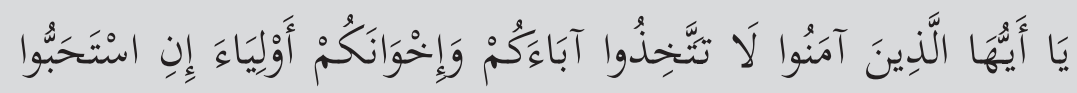

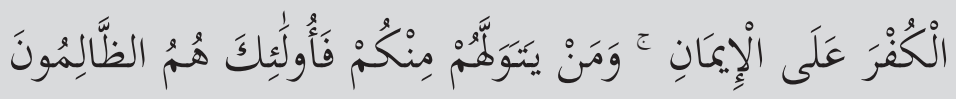

Hai orang-orang beriman, janganlah kamu jadikan bapak-bapak dan saudarasaudaramu sebagai pemimpin-pemimpin kamu, jika mereka lebih menyukai kekafiran daripada keimanan. [QS at-Taubah: 23]

Kedua, dalam pengertian "ingkar" sebagaimana firman Allah Swt.:

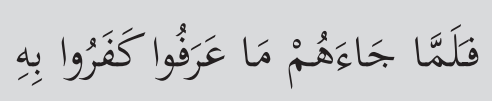

"Ternyata setelah sampai kepada mereka apa yang mereka ketahui, mereka mengingkarinya". [QS al-Baqarah: 89]

Ketiga, dalam pengertian mengingkari nikmat, sebagai lawan dari kata syukur sebagaimana firman Allah Swt.: 


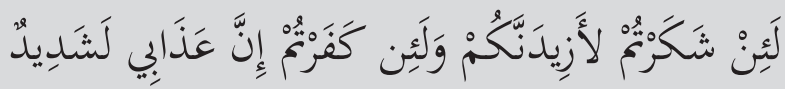

"Sesungguhnya jika kalian bersyukur, niscaya Aku akan menambah (nikmat) kepada kalian, tetapi jika kamu mengingkari (nikmat-Ku), maka pasti azab-Ku sangat berat". (QS Ibrāhīm [14]: 7)

Keempat, dalam pengertian "melepas tanggung jawab atau cuci tangan (al-bara ah)" sebagaimana firman Allah Swt.:

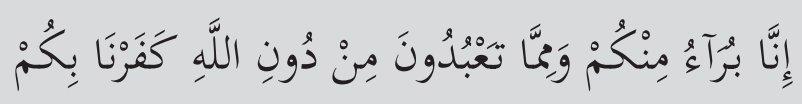

"Sesungguhnya kami berlepas diri dari kalian dari apa yang kalian sembah selain Allah, kami mengingkari (kekafiran) kalian". [QS al-Mumtaḥanah: 4]

Keempat, pengertian kufr yang digunakan dalam al-Quran ini sebagaimana dikemukakan oleh Abu al-Abbas Muqri' dalam kitab al-Lubab fi 'Ulum al-Kitab seorang ahli fikih dari kalangan Mazhab Syafii, yang sangat menguasai ilmu nahwu, tafsir, dan ilmu qira`ah sebagaimana dikemukakan oleh Imam al-Asnawi, yang dinukil oleh Ibnu Qadli Syuhbah dalam Thabaqat asy-Syafi'iyyah:

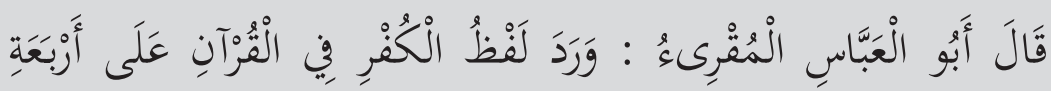

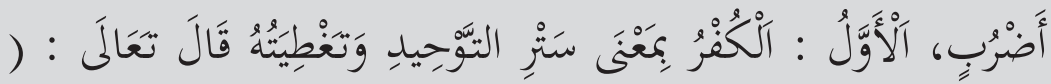

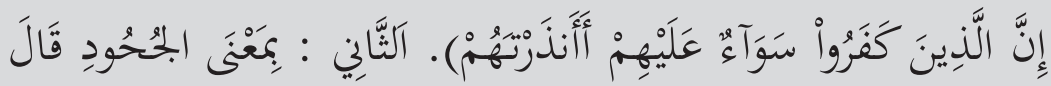

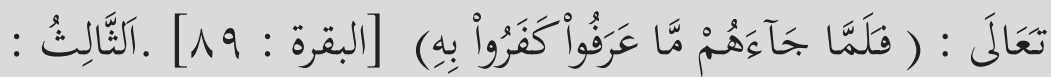




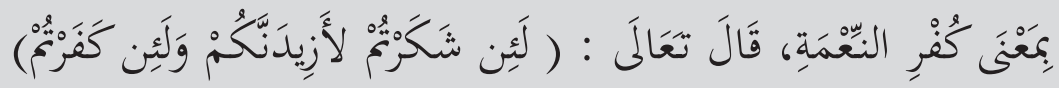

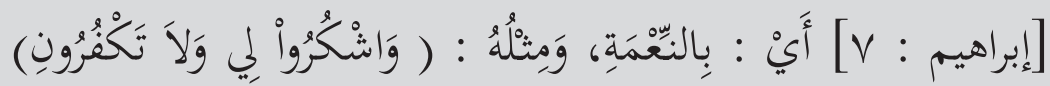

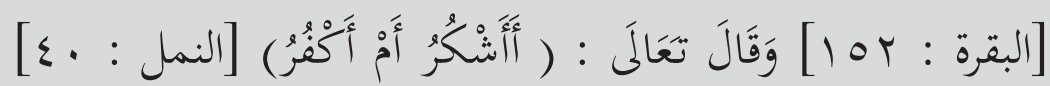

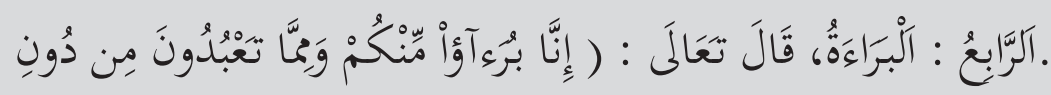

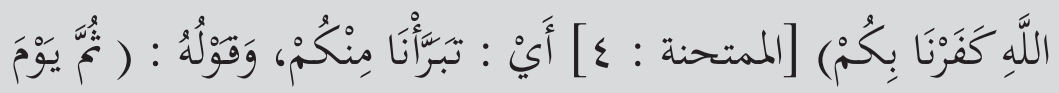

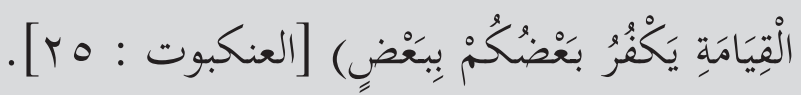

Abu al-Abbas al-Muqri berkata, kata kufr terdapat dalam al-Quran dengan empat macam pengertian. Pertama, kufr dalam pengertian menutupi ketauhidan. Allah Swt. berfirman, "Sama saja bagi mereka, engkau (Muhammad) beri peringatan." [QS al-Baqarah: 6]. Kedua, dalam pengertian ingkar (juhud). Allah Swt. berfirman: "Ternyata setelah sampai kepada mereka apa yang mereka ketahui, mereka mengingkarinya." [QS al-Baqarah: 89] Ketiga, dalam pengertian mengingkari nikmat, Allah Swt. berfirman, "Sesungguhnya jika kalian bersyukur, niscaya Aku akan menambah (nikmat) kepada kalian, tetapi jika kamu mengingkari (nikmat-Ku), maka pasti azab-Ku sangat berat." [QS Ibrāhīm: 7]. "Apakah aku bersyukur atau mengingkari (nikmatNya)." [QS an-Naml: 40]. Keempat, dalam pengertian melepas tanggung jawab. Allah Swt. berfirman, "Sesungguhnya kami berlepas diri dari kalian dari apa yang kalian sembah selain Allah, kami mengingkari (kekafiran) kalian." [QS al-Mumtaḥanah: 4], "Kemudian pada hari kiamat sebagian kamu akan saling mengingkari.” [QS al-'Ankabūt: 25].

Dalam ayat lain, kadangkala kata kufr tertuju pada orang-orang yang berputus asa. Ini seperti yang termaktub dalam surah Yusuf ayat 87: 


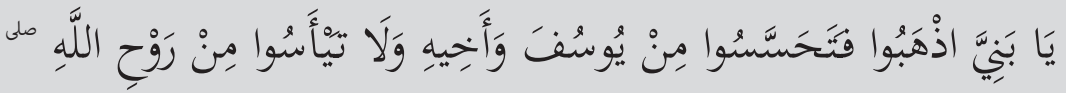

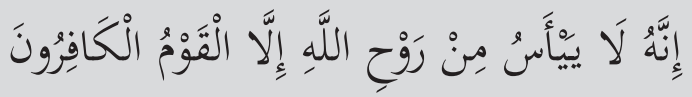

Hai anak-anakku, pergilah kamu, maka carilah berita tentang Yusuf dan saudaranya dan jangan kamu berputus asa dari rahmat Allah. Sesungguhnya tiada berputus asa dari rahmat Allah, melainkan kaum yang kafir.

Sedangkan istilah kufr secara terminologi adalah mengingkari apa yang sudah pasti datang atau dibawa oleh Rasulullah Saw. Hal ini sebagaimana yang diungkap oleh Nashiruddin al-Baidawi dalam kitab Anwar at-Tanzil wa Asrar at-Ta`wil,

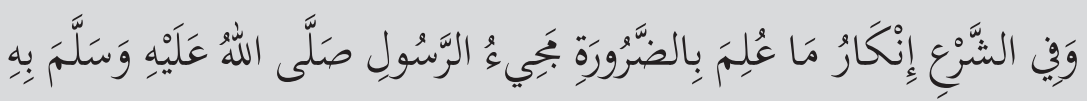

"Dan menurut syara' kufr adalah mengingkari apa yang sudah dipasti diketahui datang dari Rasūlullāh Saw".

\section{Macam-Macam Kekufuran}

Berangkat dari beragamnya makna kafir dalam al-Quran, al-Khazin dalam Tafsir al-Khazin membagi kufr itu menjadi empat macam.

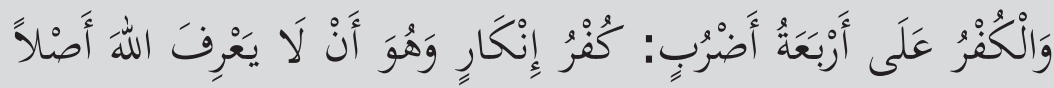

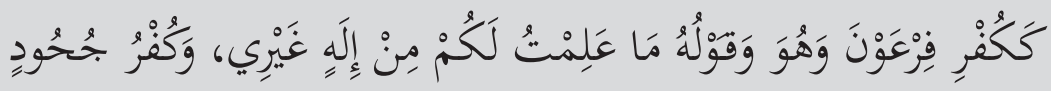

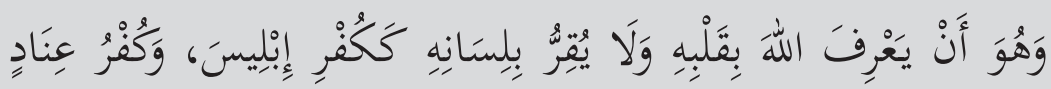




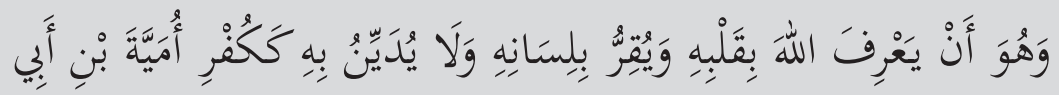

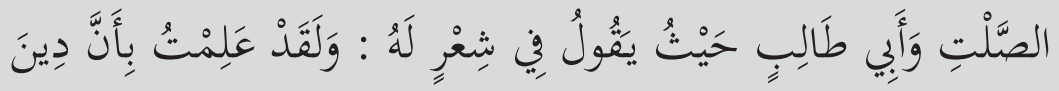

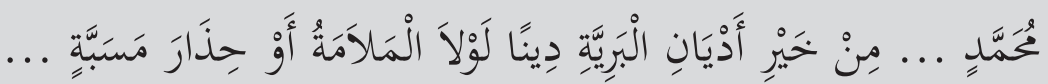

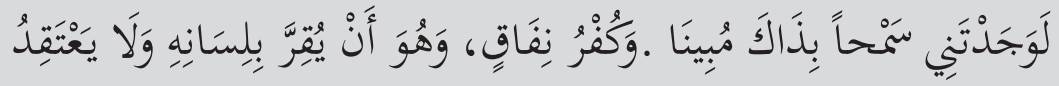

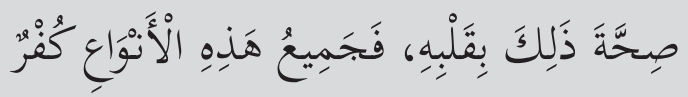

Kufr itu ada empat bentuk. Pertama, kufr ingkar yaitu tidak mengetaui Allah Swt. sama sekali seperti kufr-nya raja Fira'un dan perkataannya, 'Aku tidak mengetahui bagi kalian ada Tuhan selain aku'. Kedua, kufr juhud, yaitu mengetahui Allah Swt. dengan hatinya dan tidak menetapkan dengan lisannya seperti kufr-nya Iblis. Ketiga, kufr 'inad yaitu mengetahui Allah Swt. dengan hatinya dan menetapkan dengan lisannya tetapi tidak memeluk agamaNya, seperti kufr-nya Umayyah bin Abi ash-Shalt, dan Abi Thalib di mana ia mengungkap dalam syairnya:

'Sungguh, aku tahu bahwa agama Muhammad merupakan agama terbaik manusia. Seandainya tidak ada cercaan atau kekhawatiran dicela kamu pasti mendapatiku mau memeluknya secara jelas'. Keempat, kufr nifaq yaitu menetapkan dengan hatinya tetapi tidak menyakini kebenarannya dengan hatinya. Maka semua bentuk ini adalah kufr.

Berangkat dari pembagian ini maka dapat ditarik sebuah kesimpulan bahwa pengertian kufur adalah pengingkaran terhadap Allah Swt. atau pengingkaran terhadap ajaran yang dibawa oleh Rasulullah Saw. atau salah salah satu rasul-Nya, sedangkan kafir adalah pelakunya. Dengan demikian, orang yang mengingkari Allah Swt. atau mengingkari apa yang sudah diketahui secara pasti datang dari Rasulullah Saw. atau mengingkari kenabiannya, atau salah satu utusan Allah Swt., maka ia adalah kafir. AlKhazin mengatakan: 


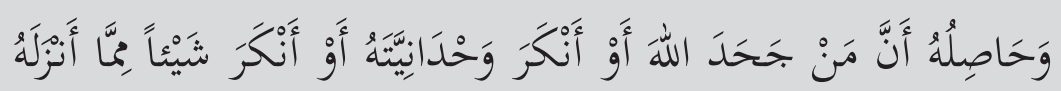

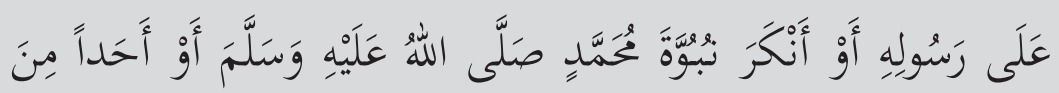

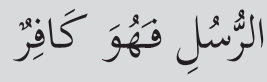

Dan kesimpulannya bahwa orang mengingkari Allah atau keesaan-Nya, mengingkari sesuatu yang Allah Swt. turunkan kepada Rasulullah Saw. atau mengingkari kenabiannya atau salah satu utusan-Nya maka ia adalah orang kafir.

Dari beragamnya makna kata kufr di atas, kita sebagai umat Islam diharapkan lebih berhati-hati dalam memahami makna al-Quran. Terlebih, di al-Quran diintrodusir sejumlah istilah lain seperti ahl al-kitab dan musyrik yang oleh sebagian kalangan awam dianggap sama belaka dengan kata kufr.

Karena ketidaktahuannya tersebut, seseorang seringkali melabeli orang yang memiliki pemahaman yang berbeda dengan kata kafir. Alih-alih kepada yang berbeda agama, kepada sesama muslim pun seringkali dijumpai pengafiran. 


\section{Larangan Mengafirkan}

Belakangan ini, kita seringkali mendapati orang yang dengan mudah menuduh kafir orang lain hanya karena berbeda pandangan, bahkan terkait dengan pandangan politik. Pengafiran kepada orang lain ini disebut takfir, yang memiliki akar kata yang sama dengan kata "kafir".

Jika kita mengaji sejarah, pengafiran kepada orang lain bukanlah sesuatu yang baru saja terjadi di tubuh umat Islam. Kelompok pertama yang menuding kafir kepada orang lain adalah Khawarij. Kelompok ini percaya kepada Allah dan Rasulullah, membaca syahadat, bahkan rajin membaca al-Quran, namun persoalan kepentingan politik membawa mereka pada kesalahan dalam menafsirkan al-Quran. Semua pandangan yang berseberangan dengan mereka dianggap sesat, keliru dan harus diberangus sampai ke akar-akarnya. Alasan yang dikemukakan adalah bahwa pandangan orang lain tersebut bertentangan dengan Islam.

Ibnu Hajar al-'Asqalani dalam kitab Fatḥ al-Bāri $\bar{i}$ Syarḥ Șaḥiḥ al-Bukhāri jus 12 , mengatakan

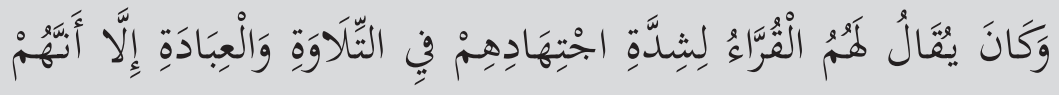

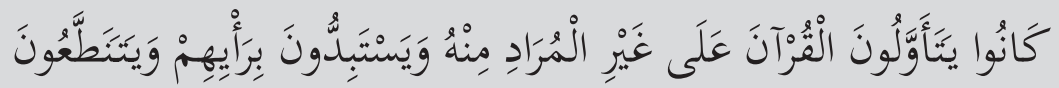

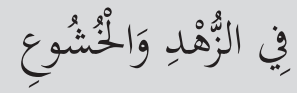

Mereka (Khawarij) disebut juga al-qurra' (para pembaca al-Quran dan ahli ibadah) karena kesungguhan mereka dalam membaca al-Quran dan ketekunannya dalam beribadah. Hanya saja mereka men-takwil (menafsirkan) al-Quran keluar dari apa yang dimaksudkan al-Quran itu sendiri, menganggap pendapatnya paling benar, dan bersikap zuhud dan khusu' yang dibuat-buat dan tampak dipaksakan. 
Terus terang, mengafirkan orang lain yang selagi memegang teguh rukun iman dan melaksanakan rukun Islam jelas-jelas dilarang. Imam Muḥyiddin Syaraf an-Nawawi dalam kitab Riyādu aș-Ṣālihīn-nya mengumpulkan hadishadis yang menunjukkan keharaman mengafirkan sesama muslim. hadishadis tersebut kemudian dijadikan satu bab tersendiri, yaitu bab Tahrīimu Qaulihi li al-Muslim: Ya Kafir (bab keharaman seorang muslim mengatakan "hai kafir" kepada muslim yang lain). Di antaranya adalah hadis berikut ini:

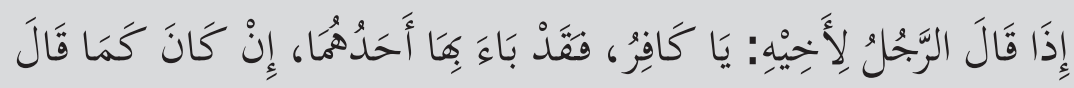

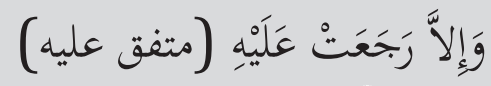

Ketika seseorang berkata kepada saudaranya, "hai kafir" maka kalimat tersebut akan kembali ke salah satu di antara keduanya, apabila hal tersebut sebagaimana yang ia katakan, jika tidak maka akan kembali kepada dirinya (si pengucap). [HR Muttafaq 'Alaih]

hadis ini memberi peringatan kepada kita agar tidak sembarangan memvonis orang lain dengan vonis kafir. Sebab, jika tuduhan tersebut tidak benar maka akan menjadi senjata makan tuan.

Bahkan larangan untuk mengafirkan sesama muslim secara sahih juga dapat kita lihat dalam hadis yang diriwayatkan oleh Ibnu Umar yang terdapat dalam al-Mu'jam al-Kabir karya Imam ath-Tabrani.

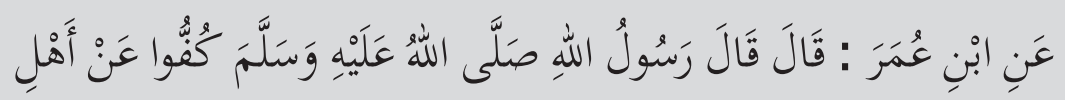

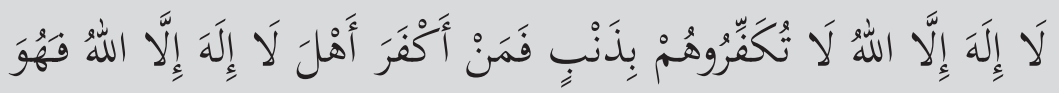

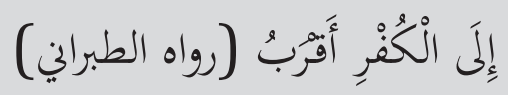


Dari Ibnu Umar ia berkata, Rasūlullāh Saw. bersabda: tahanlah diri kalian (menyerang) ahli lā ilaha illallah, jangan kalian mengafirkan mereka karena suatu dosa. Karena orang yang mengafirkan ahli lā ilaha illallah maka ia lebih dekat kepada kekafiran. (HR ath- Tabrani)

Menurut Abdurrauf al-Munawai, maksud dari ahl lā ilāha illallah dalam hadis tersebut adalah orang-orang yang mengatakan lā ilaha illallah muhammad ar-rasūlullāh, meskipun apa yang ada dalam hatinya tidak diketahui. Mengafirkan mereka tidak diperbolehkan meskipun dosa yang dilakukannya adalah dosa besar seperti membunuh, zina, dan mencuri.

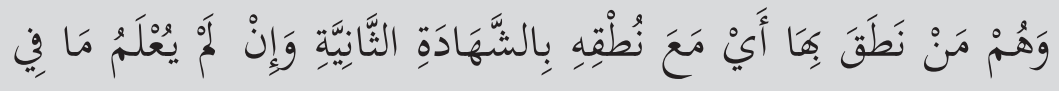

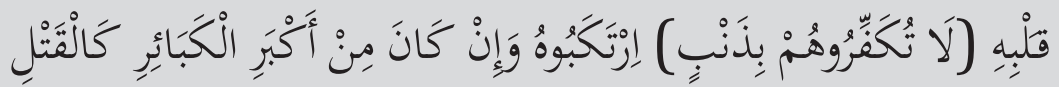

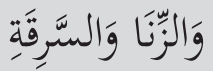

Mereka adalah orang-orang yang mengucapkan lā ilaha illallah artinya mengucapkan dengan dibarengi syahadat yang kedua (muhammad rasūlullāh) meskipun apa yang ada dalam hatinya tidak diketahui. (Jangan kalian mengafirkan mereka karena suatu dosa) yang mereka lakukan meskipun itu dosa yang paling besar seperti membunuh, zina, dan mencuri [Abdurrauf alMunawi: 1415H, h.12]

Penjelasan Abdurrauf al-Munawi tersebut mengandaikan bahwa seorang yang telah mengucapkan dua kalimat syahadat (muslim) meskipun ia melakukan dosa besar tidak serta merta boleh dicap kafir. Karena konsekuensi logis dari tuduhan kafir adalah kehalalan darah dan hartanya.

Padahal harta dan darah orang muslim itu adalah sesuatu yang diharamkan bagi siapapun kecuali memang ada alasan yang dibenarkan. Keharaman harta dan darah orang muslim telah ditegaskan sendiri oleh Rasulullah 
Saw. dalam khotbah pada Haji Wada` (haji perpisahan). Ath-Thahawi, dalam Syarh Ma'ani al-Aṡar mengatakan

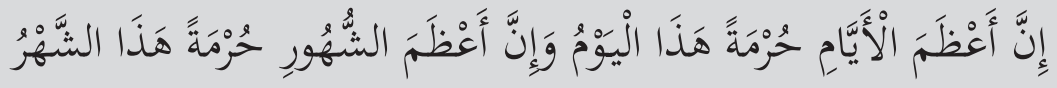

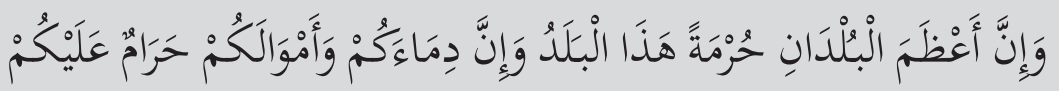

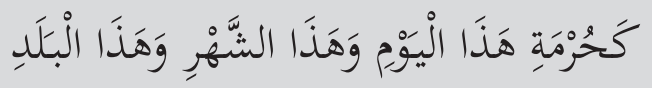

Sungguh, hari yang paling agung kesuciannya adalah hari ini, bulan yang paling agung kesuciannya adalah bulan ini, dan negeri yang paling agung kesuciannya adalah negeri ini. Sungguh, darah dan harta kalian itu haram atas kalian seperti kesucian hari ini, bulan ini, dan negeri ini.

Karena itulah maka doktrin anti pengafiran terhadap sesama muslim menjadi doktrin yang sangat penting dalam teologi ahl as-sunnah wa aljama'ah dan menjadi salah satu ciri khas dari mereka. Imam Abu al-Hasan Asy'ari sebagai tokoh penting dalam teologi ahl sunnah wa al-jama'ah dengan tegas menyatakan:

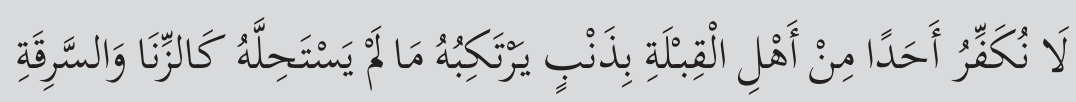

$$
\begin{aligned}
& \text { وَشُرْبِ الأنْْْرِ }
\end{aligned}
$$

"Kami tidak mengafirkan seorang pun dari ahli kiblat sebab, dosa yang dilakukannya sepanjang mereka tidak menganggap halal seperti zina, mencuri, dan meminum khamr" [Abu Hasan al-Asy'ari, al-Ibanah 'an Ushul adDiyanah, Bairut-Dar al-Kutub al-Ilmiyyah, 2005 M, h. 17].

Dalam konteks ini, Imam Abu Hamid al-Ghazali dalam kitab al-lqtiṣad fi al-l'tiqad (h. 308) mengingatkan kepada kita agar berhati-hati dan 
berusaha sebisa mungkin menghindari memberikan cap kafir kepada sesama muslim. Bahkan beliau sampai pada kesimpulan bahwa kekeliruan membiarkan seribu orang kafir tetap hidup itu masih lebih ringan ketimbang menumpahkan darah seorang muslim. Hal ini dapat kita lihat dari dua pernyataan beliau di bawah ini;

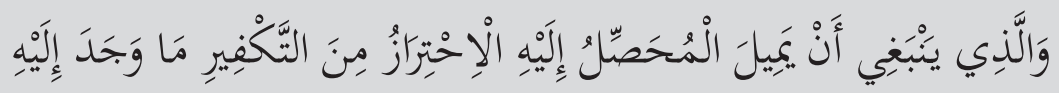

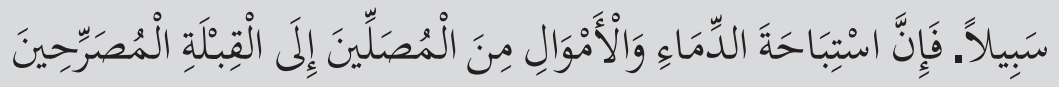

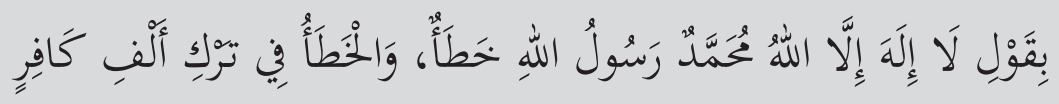

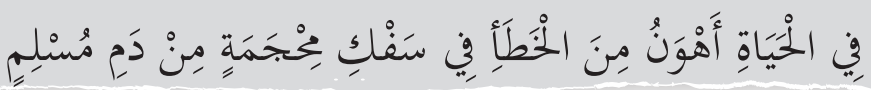

Sikap yang sebaiknya diambil oleh pencari kebenaran adalah menghindari dari mengafirkan orang lain selama ia menemukan jalan untuk menghindarinya. Karena sesungguhnya menghalalkan darah dan harta-benda orang-orang yang salat menghadap ke kiblat, yang nyata-nyata mengucapkan lā ilaha illallah muhammad ar-rasūlullāh, adalah kesalahan. Sedang kesalahan membiarkan seribu orang kafir tetap hidup itu lebih ringan ketimbang kesalahan menumpahkan darah seorang muslim. [Imam Abu Hamid al-Gazali dalam kitab al-lqtișad fi al-l'tiqad, h. 308]

Dalam literatur lain, Abu Hamid al-Gazali mengatakan:

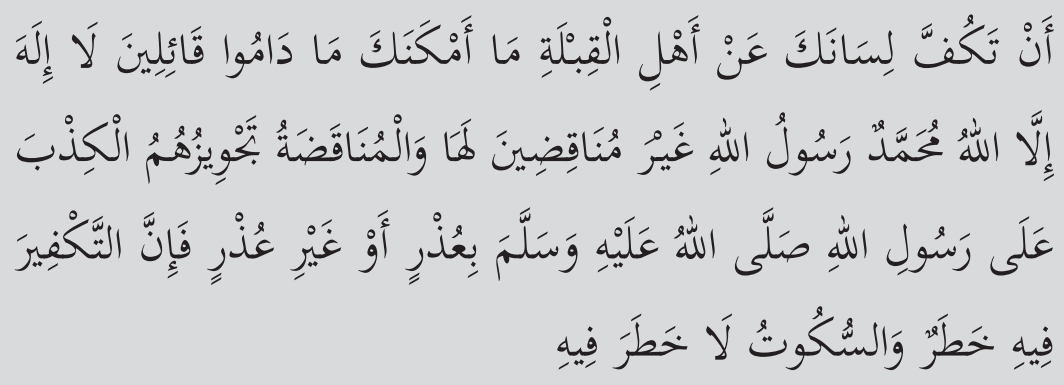


Hendaknya kamu sebisa mungkin menjaga lisanmu dari (menuduh kafir) ahli kiblat selama mereka mengucapkan kalimat lā ilaha illallah muhammad ar-rasūlullāh, tidak menentangnya. Sedangkan menentangnya adalah membolehkannya mereka mendustai Rasūlullāh Saw. baik disebabkan użuratau tidak. Sebab, pengafiran dalam hal ini adalah sangat berbahaya. Sedangkan diam (tidak mengafirkan) itu tidak berbahaya. [Faishal at-Tafriqah yang dinukil dalam Majmu` ar-Rasail li al-Imam al-Gazali h. 89]

Dengan demikian menghindari memberikan vonis kafir kepada sesama muslim menjadi sebuah keniscayaan karena dampak buruk yang ditimbulkan darinya. 


\section{BABEMPAT}

\section{MENJAWAB POKOK MASALAH FIKIH}

$\mathrm{F}$

ikih atau hukum Islam bukanlah al-Quran dan hadis. Fikih adalah rumusan atau hasil pemikiran ulama atau para ulama terhadap suatu masalah tertentu dengan berlandaskan pada sumber-sumber hukum Islam, yakni al-Quran dan hadis. Karena itulah, fikih tidak boleh bertentangan dengan al-Quran dan hadis atau sunah. al-Quran dan hadis bersifat qat'i iatau pasti dan tidak berubah, sementara fikih bersifat relatif (zannī), bisa berubah.

Jika demikian, apakah boleh kita langsung merujuk kepada sumber utama, yaitu al-Quran dan hadis, yang bersifat pasti dengan mengesampingkan fikih yang relatif karena ia adalah hasil pemikiran ulama? Jawabannya, benar bahwa kita harus merujuk kepada al-Quran dan hadis. Namun, apakah al-Quran dan hadis memberikan jawaban atas semua persoalan yang ada secara gamblang? 
Perlu diketahui bahwa tidak semua ayat dalam al-Quran bisa dipahami secara tekstual atau harfiyah. Juga, tidak semua ayat dalam al-Quran memberikan penjelasan yang utuh dan siap untuk langsung dipraktikkan. Para ulama mengklasifikasikan ayat-ayat al-Quran ke dalam beberapa kategori; muhkamat vs mustasyabihat, muthlak vs muqayyad, 'am vs khaș, mujmal vs mubayyan, dan lain sebagainya.

Contoh, al-Quran memerintahkan kita untuk salat. Akan tetapi, jika ditelusuri dalam al-Quran, tidak ada ketentuan bagaimana kita melaksanakan salat, bagaimana ruku', sujud, tasyahud, dan lain sebagainya. Untuk mengetahui bagaimana praktik salat tersebut, kita dapat menjumpainya dalam hadis nabi, baik melalui perkataan nabi langsung, ataupun melalui penglihatan para sahabat terhadap praktik salat tersebut.

Contoh lainnya, dalam surah al-Isrā ayat 23, Allah berfirman:

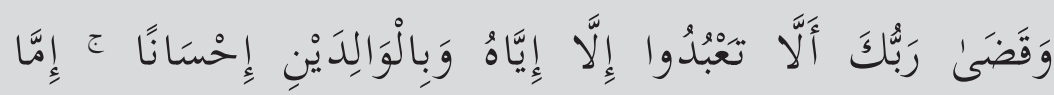

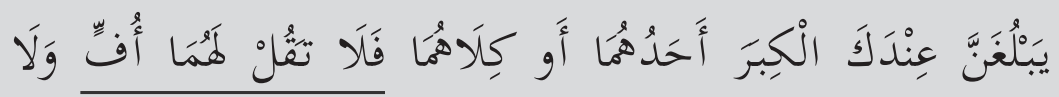

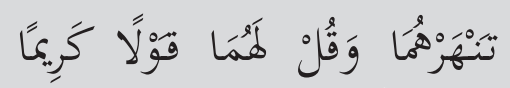

Dan Tuhanmu telah memerintahkan supaya kamu jangan menyembah selain Dia dan hendaklah kamu berbuat baik pada ibu bapakmu dengan sebaikbaiknya. Jika salah seorang di antara keduanya atau kedua-duanya sampai berumur lanjut dalam pemeliharaanmu, maka sekali-kali janganlah kamu mengatakan kepada keduanya perkataan "ah" dan janganlah kamu membentak mereka dan ucapkanlah kepada mereka perkataan yang mulia. [QS al-Isrā:23]

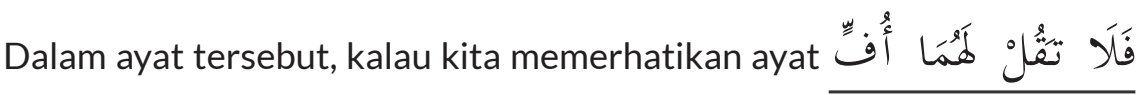
sangat terang bahwa yang dilarang adalah berkata "uff" atau "ah". Apakah memukul orang tua diperkenankan karena tidak ada larangan dalam ayat tersebut? Jika kita terpaku pada terjemah harfiyah ayat tersebut, maka 
yang dilarang adalah berkata "uff" atau "ah", sementara tidak ada larangan untuk menyakiti, memukul bahkan membunuh orang tua. Dari ayat inilah, para ulama kemudian menyimpulkan bahwa berkata "uff" atau "ah" saja dilarang, apalagi memukul, menyakiti atau membunuhnya yang levelnya lebih tinggi daripada berkata "uff" atau "ah". Ini disebut dengan qiyas aulawi.

Contoh lain bisa kita lihat pada surah an-Nisa ayat 23:

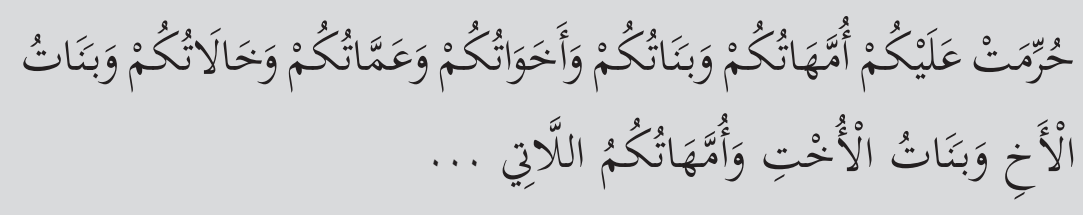

Diharamkan atas kamu (mengawini) ibu-ibumu; anak-anakmu yang perempuan; saudara-saudaramu yang perempuan, saudara-saudara bapakmu yang perempuan; saudara-saudara ibumu yang perempuan; anak-anak perempuan dari saudara-saudaramu yang laki-laki; anak-anak perempuan dari saudara-saudaramu yang perempuan; ibu-ibumu yang menyusui kamu... [QS an-Nisa ayat 23]

Ayat di atas tidak tertulis penjelasan dalam konteks apa keharaman ini. Apakah kita diharamkan mencintai ibu? Ataukah kita diharamkan membunuh ibu. Para ulama kemudian memberikan penjelasan bahwa yang diharamkan pada atas tersebut adalah mengawini ibu.

Dari contoh-contoh di atas, kita menjadi sadar bahwa hanya dengan mengandalkan al-Quran dan hadis ternyata tidak memudahkan kita dalam mempraktikkan Islam, yang terjadi justru kebingungan. Terlebih jika kita hendak merespons masalah kekinian yang secara harfiah tidak ditemui dalam al-Quran dan hadis. Misalnya, bagaimana kita memberikan hukum terhadap bunga bank yang pada masa nabi belum ada sistem perbankan. Karena itulah, kita perlu uluran tangan para ulama yang telah merumuskan hukum-hukum Islam, sehingga memudahkan kita memahami al-Quran dan hadis. 
Untungnya di Indonesia, terdapat institusi seperti Lembaga Bahsul Masail Nahdlatul Ulama (LBMNU), Komisi Fatwa Majelis Ulama Indonesia (MUI) dan Majelis Tarjih Muhammadiyah yang secara rutin mengeluarkan sejumlah ketentuan hukum terhadap peristiwa kekinian yang terjadi di Indonesia.

Institusi tersebut terasa sangat penting, karena untuk menentukan sebuah hukum harus dilakukan oleh seorang mujtahid (orang yang melakukan ijtihad) yang memiliki persyaratan yang tidak mudah, yakni penguasaan ilmu-ilmu kelslaman seperti hafal al-Quran, ribuan hadis, menguasai ilmu metodologi Islam seperti uṣūl figh, qawaid tafsir, dan lain sebagainya, serta penguasaan atas masalah yang hendak dipecahkan. Singkatnya, penentuan sebuah hukum tidak serta merta hanya berdasarkan satu dalil, melainkan juga memerlukan perangkat penelitian yang mendalam. 


\section{Islam Tidak Bermazhab}

Belakangan muncul kesadaran di kalangan umat Islam tentang tidak pentingnya merujuk kepada imam mazhab. Mereka mengajak untuk langsung merujuk kepada al-Quran dan hadis. Gagasan dan gerakan ini semula dikembangkan oleh Ibnu Taimiyah (wafat $728 \mathrm{H}$ ) yang kemudian dikembangkan oleh Muhammad Abduh.

Mereka menolak pendapat-pendapat yang dikembangkan oleh Imam Hanafi yang lahir pada tahun 80 Hijriyah dan wafat tahun 150 Hijriyah, Imam Malik yang lahir pada tahun 93 Hijriyah dan wafat 179 H, Imam Syafii yang lahir pada 150 Hijriyah dan wafat 204 Hijriyah, dan Imam Hambali yang lahir pada 164 Hijriyah dan wafat 248 Hijriyah, serta imam mazhab lainnya. Bagi mereka, merujuk kepada al-Quran dan hadis yang terutama diriwayatkan oleh Imam muslim dan Imam Bukhari itu lebih benar ketimbang merujuk kepada empat imam mazhab dalam fikih tersebut.

Sebelum lebih jauh, penting kiranya mengerti apa itu mazhab. Kata mazhab berasal dari bahasa Arab "żahaba" yang berarti pergi. Kata mazhab yang merupakan bentuk isim makan (kata yang menunjukkan tempat) bermakna tempat bertolak untuk pergi. Dalam kamus al-Maany, kata mazhab didefinisikan sebagai berikut:

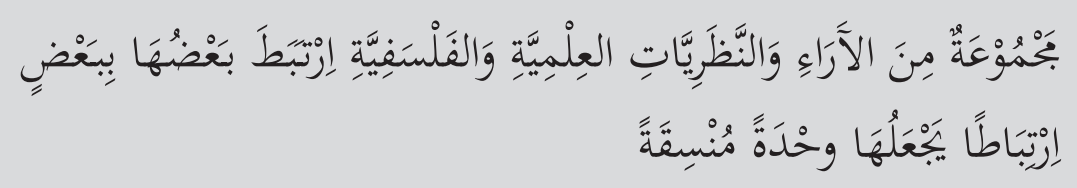

Kumpulan pendapat dan teori keilmuan atau filsafat, yang saling bertalian satu sama lain, hingga membentuk satu kesatuan yang padu.

Dalam konteks fikih, bermazhab berarti merujuk kepada salah satu atau lebih pendapat imam atau ulama yang telah melakukan ijtihad (kegiatan menggali hukum-hukum yang terkandung dalam al-Quran dan sunah). 
Apakah diperbolehkan seseorang melakukan ijtihad? Jelas diperbolehkan mengingat ada banyak persoalan atau peristiwa yang belum terjadi di masa nabi yang membutuhkan kepastian hukum. hadis yang diriwayatkan oleh At-Tirmiżi menyebutkan bagaimana ijtihad ini secara implisit diperbolehkan oleh Nabi Muhammad, sebagaimana yang terekam dalam dialog antara Muaż bin Jabal dengan Nabi Muhammad.

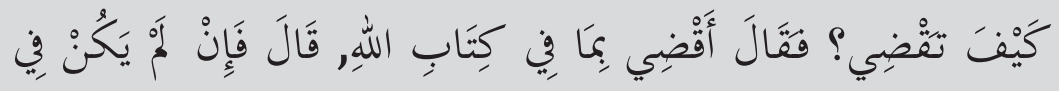

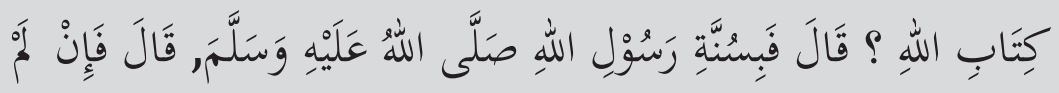

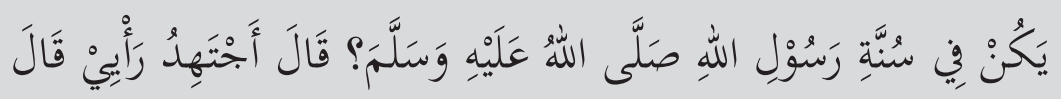

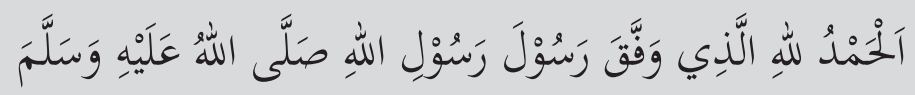

Bagaimana kamu mengambil dasar hukum? Muaż menjawab, "aku akan menghukumi perkara dengan apa yang terdapat di dalam al-Quran. Rasul bertanya, "Jika tidak ada di dalam al-Quran?" Muaż menjawab, "aku akan menghukumi dengan apa yang terdapat di dalam sunah Rasūlullāh shallallāhu 'alayhi wa sallam." Rasul bertanya, "Jika tidak terdapat di dalam sunah Rasūlullāh shallallāhu 'alayhi wa sallam?" Muaż menjawab; "Aku berijtihad dengan pendapatku." Rasul menjawab; "Segala puji bagi Allah, yang telah memberi petunjuk kepada utusan Rasūlullāh shallallāhu 'alayhi wa sallam.

Namun demikian, tidak semua orang dapat melakukan ijtihad atau mengeluarkan sebuah hukum, apalagi hanya berdasarkan pada satu dalil. Diperlukan syarat-syarat yang cukup ketat. Sekurang-kurangnya, ada 5 pokok ilmu yang harus dikuasai. Pertama, ilmu al-Quran. Seorang mujtahid bukan hanya dituntut untuk hafal al-Quran, melainkan juga menguasai sejumlah ilmu terkait dengan al-Quran, seperti 'ulumul al-Qur'an, ragam qira'at, asbab an-nuzul, nasikh mansukh, dan lain sebagainya. 
Kedua, menguasai ilmu hadis. Di sini, seorang mujtahid bukan saja hafal seratus atau seribu hadis, melainkan juga harus mengerti ilmu hadis ('ulūm al-hadìis), Ilmu Jarh wa ta'dil, ilmu gharib al-hadis, kritik sanad dan matan serta ilmu lainnya. Karena banyaknya cabang keilmuan untuk memahami dua sumber tersebut, di perguruan tinggi Islam seperti UIN/ STAIN, ditemukan satu program studi tersendiri yang memang fokus pada ilmu-ilmu tersebut, seperti jurusan tafsir, dan jurusan hadis.

Ketiga, menguasai ilmu bahasa Arab. Karena sumber utama Islam; al-Quran dan hadis, menggunakan bahasa Arab maka menguasai bahasa Arab adalah sebuah keharusan. Dalam mempelajari bahasa Arab, seseorang akan menempuh sejumlah cabang ilmu seperti nahwu, șaraf, balagah, mantiq dan lain sebagainya. Di pesantren-pesantren, untuk bisa membaca kitab kuning membutuhkan waktu yang tidak singkat.

Keempat, menguasai ilmu ușūl al-fiqh. Secara definitif, Abu Ishak As-Syirazi dalam kitab al-Luma mendefinisikan ușūl al-figh sebagai berikut:

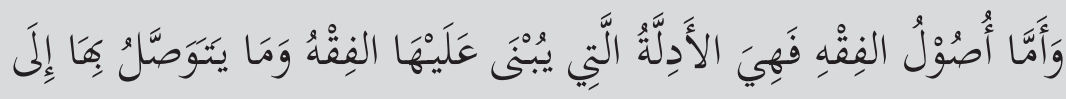

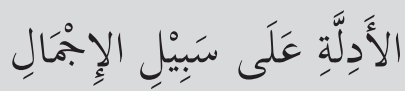

Ușūl al-figh ialah dalil-dalil penyusun fikih, dan metode untuk sampai pada dalil tersebut secara global.

Dengan merujuk pada al-Quran dan hadis, melalui uṣūl al-figh inilah, lahir hukum wajib, haram, sunah, makruh, mubah dan lain sebagainya. Dengan menguasai ilmu ușūl al-figh dan bahasa Arab, seseorang dapat mengerti apakah suatu ayat masuk kategori ayat 'am, khas, mutlak, muqayyad, mujmal, mubayyan, mantuq, mafhum, dan lain sebagainya. 
Kelima, ijma'. Seorang mujtahid juga harus memahami ijma', yaitu kesepakatan ulama pada zaman setelah Rasulullah atas suatu perkara dalam agama. Ini penting sebagai landasan bahwa ketentuan hukum yang kita percayai hari ini telah disepakati oleh para ulama. Secara metode, ada dua jenis ijma' yakni: 1) ljma' bayāni/șarih, yaitu ijma' yang terjadi baik dengan perkataan maupun perbuatan, seperti perbuatan para ulama salaf yang berbisnis menggunakan model mudarabah, 2) ijma' sukuti, yakni diamnya ulama terhadap perbuatan atau tradisi di masa lalu.

Lembaga Bahsul Masail NU mengaplikasikan pendekatan bermazhab ini kepada tiga macam metode penggalian hukum yang diterapkan secara berjenjang. Pertama, Metode qauli (tekstual), yakni metode dengan merujuk langsung pada pendapat imam mazhab empat atau ulama yang mengikutinya. Kedua, metode ilhaqi, yaitu metode yang berusaha menyamakan hukum suatu kasus yang belum ada ketentuan hukumnya dengan kasus yang telah diputuskan oleh para imam mazhab. Ketiga, metode manhaji (metodologis), yaitu penyelesaian suatu masalah hukum dengan langsung merujuk pada metode yang dikembangkan oleh imam mazhab, seperti uṣūl fiqh Imam Syafii.

Yang menarik sekaligus lucu dari gerakan ini adalah penolakan terhadap para imam mazhab seperti Imam Hanafi, Imam Malik, Imam Syafii dan Imam Ahmad Bin Hambal, dan langsung merujuk kepada buku-buku hadis dari Bukhari, muslim, Tirmiżi, Abi Daud dan lain sebagainya.

Padahal, secara periodik, imam mazhab tersebut lebih dahulu ketimbang ulama-ulama hadis. Sebagai perbandingan, Imam muslim lahir pada tahun 206 Hijriyah sementara Imam Hanafi lahir pada tahun 80 Hijriyah. Apa pentingnya menyuguhkan periode kelahiran ini? Ini artinya, silsilah keilmuan seseorang yang lahir lebih dahulu lebih dekat dengan para tabi'in, sahabat dan Rasulullah. Mari kita lihat guru-guru Imam Syafii, misalnya. Imam Syafii berguru kepada muslim bin Khalid Az-Zanji yang berguru kepada Muhammad bin Juraij yang berguru kepada Ața bin Rabah yang berguru kepada Ibnu Abbas yang berguru kepada Rasulullah. 
Perbandingan tahun lahir imam mazhab dengan imam hadis

\begin{tabular}{|c|c|c|c|}
\hline Imam Mazhab & Lahir & Imam Hadis & Lahir \\
\hline Imam Hanafi & $80 \mathrm{H}$ & Imam Bukhari & $196 \mathrm{H}$ \\
\hline Imam Malik & $93 \mathrm{H}$ & Imam Muslim & $202 \mathrm{H}$ \\
\hline Imam Syafii & $150 \mathrm{H}$ & Abu Daud & $202 \mathrm{H}$ \\
\hline Imam Hambali & 164 & Tirmiżi & $209 \mathrm{H}$ \\
\hline
\end{tabular}

Karena periode imam mazhab lebih awal ketimbang imam hadis, maka dapat dipastikan imam hadis juga merujuk atau bermazhab kepada imam mazhab. Imam Bukhari, Imam muslim, Imam Nasa'i, Imam Baihaqi, Imam Tirmiżi, Imam Ibn Majah, misalnya, adalah imam-imam hadis yang bermazhab Imam Syafii.

Karena itulah, para imam mazhab menulis sejumlah hadis serta menyelipkan hadis ke dalam sejumlah karyanya, seperti kitab al-Muwatta' yang dikarang oleh Imam Malik yang menghimpun 10.000 hadis. Imam Malik sendiri menerima hadis dari 900 guru, 300 dari golongan tabi'in dan 600 dari golongan tabi'it tabi'in.

Dari paparan di atas, menolak mazhab yang ditujukan untuk menjaga kemurnian Islam menjadi tidak relevan. Sebaliknya, kita perlu berterima kasih kepada imam mazhab tersebut karena kehadirannya justru memudahkan kita dalam menemukan ketentuan hukum. Karena itulah, bermazhab bukan tidak mengikuti Rasul, justru sebaliknya, dengan bermazhab kita mengikuti Rasul. 


\section{Hukum Hanya Milik Allah}

Dewasa ini, tak jarang para dai menggunakan jargon "Hukum hanya milik Allah"dalam setiap khotbahnya, yang sebelumnya sering disampaikan oleh Abu Bakar Ba'asyir dalam setiap ceramahnya sebelum ia dipenjara. Secara eksplisit pernyataan tersebut mengajak umat Islam di Indonesia untuk tidak mematuhi hukum yang dibuat oleh manusia, termasuk di dalamnya adalah konstitusi. Dengan alasan, hukum manusia memiliki kelemahan oleh karenanya yang perlu diikuti adalah hukum Allah yang telah menciptakan manusia, hukum Allah adalah satu-satunya hukum yang benar dan yang harus diikuti oleh manusia.

Gagasan ini, sering dijadikan argumen dan digunakan sebagai senjata dalam berdakwah oleh kelompok gerakan Islam radikal untuk menolak pemerintahan yang sah dan menolak konstitusi. Pemahaman mereka mengenai gagasan bahwa "hukum hanya milik Allah" secara teologis didasarkan kepada surah al-Maidah ayat 44:

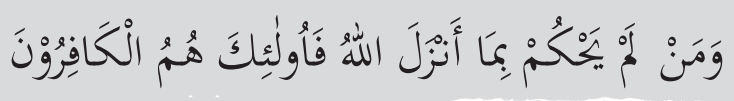

Siapa yang tidak berhukum kepada hukum yang diturunkan Allah, maka mereka adalah orang-orang kafir. [QS al-Maidah: 44]

Implikasi dari pemaknaan ayat di atas menurut Ba'asyir dalam bukunya "Keindahan Syariah dan Keagungan al-Quran", adalah orang yang tidak menegakkan hukum Allah termasuk kepada kategori orang-orang kafir. Oleh kerenanya, harus ditegakkan hukum Allah, karena ketika tidak tunduk dan patuh kepada hukum Allah, maka menurut ijma' ulama dikatakan kafir. Pertanyaanya adalah, apa dan bagaimana menegakkan hukum Allah?

Pernyataan "Hukum hanya milik Allah" tak jarang disalahpahami oleh sebagian umat Islam, hingga akhirnya dengan sangat mudah mengafirkan bahkan memerangi sesama muslim. 
Sejarah Islam telah mencatat bahwa pada akhir abad ke-1 Hijriyah, terdapat golongan Khawarij yang dengan lantang mengucapkan kalimat "Lā hukma illa lillāh" yang bermakna "tidak ada hukum selain hukum Allah," sebagai moto dalam menegakkan Islam dengan menegakkan hukum Allah. Kalimat ini pertama kali diucapkan sebagai bentuk penolakan tahkim atau arbitrase yang terjadi pada perang Shiffin antara Sayyidina Ali ra. dan Muawiyah bin Abu Sofyan. Jargon tersebut didasarkan penggalan ayat 40 surah Yusuf:

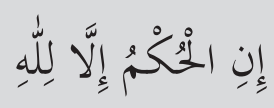

Keputusan (menetapkan hukum) itu hanyalah milik Allah.. [QS Yusuf: 40]

Menyikapi hal tersebut M. Quraish Shihab dalam bukunya Wawasan al-Quran mengatakan bahwa secara lahiriah atau lafziyah kata tersebut benar, namun secara substansi terdapat kekeliruan. Sebagaimana yang diutarakan oleh Ali bin Abi Thalib:

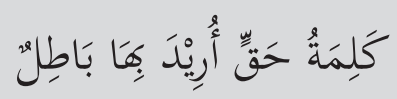

Kalimat yang benar, tapi yang dimaksudkan batil (salah)

Kekeliruan yang dimaksud adalah hukum Allah tidak bisa dipahami secara literal atau tekstual dalam ayat di atas. al-Quran sebagai sumber hukum Islam tidak semua penjelasannya dapat dipahami langsung oleh manusia, sehingga diturunkanlah hadis untuk menafsirkan dan menjelaskan ayat-ayat dalam al-Quran. Begitu pula dengan hukum. Ayat- ayat dalam al-Quran ada yang bersifat (pasti) seperti ayat yang memerintahkan untuk melaksanakan salat. Perintah mendirikan salat "wa aqīmuṣ șalāta" terdapat kata 'amryang dalam kaidah ușul al-figh bermakna "kata perintah" menunjukkan wajib. Maka hukum mendirikan salat adalah wajib. 
Kedua, adalah ayat-ayat yang bersifat z̧anni (prasangka) atau dalam istilah Imam asy-Syatibi mengandung makna lain, di mana ayat tersebut mengandung banyak makna (musytarak) sehingga terdapat perbedaan antara para ulama untuk menafsirkan ayat tersebut. Implikasinya terdapat perbedaan hukum dalam memahami ayat-ayat musytarak. Oleh karenanya, penetapan hukum pada ayat-ayat dengan makna musytarak tidak besifat tunggal. Seiring dengan perkembangan zaman, banyak persoalan-persoalan manusia yang secara spesifik tidak dibahas dalam al-Quran, seperti ayat tentang perdagangan manusia (trafficking) yang secara teknis berbeda dengan praktik perbudakan pada masa Rasulullah hidup. Juga tidak dijumpai ayat yang berbicara tentang bayi atau surrogate mother (sewa rahim). Hal yang sama juga tidak dijumpai di dalam sunah.

Dengan tidak dijumpainya persoalan-persoalan kontemporer yang diatur di dalam al-Quran dan sunah itu, Rasulullah mengizinkan umatnya untuk melakukan ijtihad. Itu yang dipahami dari dialog antara Rasulullah dengan Muaẓ bin Jabal untuk berijtihad dalam menjawab persoalan kontemporer.

Pertanyaan selanjutnya adalah apa yang dimaksud dengan hukum Allah? Menurut Muhammad Machasin, hukum dapat dipahami sebagai ketentuan yang mengatur atau memberikan ruang yang di dalamnya subjek yang berkenaan boleh berbuat dan batas-batas yang tidak boleh dilanggar.

Dari batasan definisi di atas, menurut Machasin, hukum Allah terdapat beberapa tingkatan.

Pertama, tingkatan seluruh wujud, yakni dikenal dengan sunatullah, atau hukum alam. Bahwa semua makhluk berada dalam kondisi yang sesuai dengan kodratnya; makhluk hidup tumbuh dan berkembang biak, perputaran siang dan malam.

Kedua, tingkatan hubungan antar manusia. Pada proses alamiah yang berkaitan dengan tubuh dan perkembangan manusia, berlaku hukum alam, sementara hal-hal yang berkaitan dengan kehendak dan perbuatan manusia dengan orang lain, berlaku hukum-hukum Allah yang khas untuk manusia, yang disebut dengan hukum sosial. Termasuk di dalam hukum 
alam dan sosial ini adalah apa yang dapat dipahami dari hadis nabi bahwa jiwa bertabiat mengelompok, yang saling memahami akan bergabung, sementara yang tak saling memahami akan bercerai.

Ketiga, hukum Allah yang bekerja pada tataran perilaku manusia yang dikaitkan dengan keimanan kepada-Nya. Di sini hukum itu berupa ketentuan-ketentuan yang diturunkan Allah kepada umat manusia. Akan tetapi, wahyu Allah yang turun kepada manusia itu terbatas karena sudah selesai proses turunnya, sementara persoalan yang dihadapi manusia terus bertambah. Karena itu diperlukan metodologi untuk memahami pesan dasar yang ada pada wahyu agar dapat memberikan pegangan kepada mereka di mana pun dan kapan pun.

Di sinilah lalu muncul pentingnya petunjuk Nabi yang sejak proses turunnya al-Quran sudah memberikan penjelasan dan kadang-kadang perincian, pembatasan pengertian, perluasan makna dan sebagainya. Kemudian datang pula praktik pengamalan generasi awal setelah Nabi wafat, kebiasaan di suatu tempat ('urf) dan penalaran.

Selain itu, banyak dari teks-teks al-Quran mengandung kemungkinan pemahaman yang berbeda-beda. Karena itu diperlukan ijtihad atau usaha keras untuk menangkap ketentuan yang dimaksudkannya. Di sinilah lalu muncul perbedaan pendapat di antara para ulama mengenai ketentuan atau hukum Allah yang berkaitan dengan perbuatan manusia (mukallaf).

Dengan demikian, apa yang disebut dengan hukum Allah pada tingkatan ini adalah pemahaman manusia terhadap firman Allah. Boleh juga dikatakan bahwa yang sering kali disebut hukum Allah dalam hal ini adalah hukum buatan manusia yang didasarkan pada firman Allah atau hukum yang dinisbahkan kepada Allah.

Pertanyaan selanjutnya adalah, bagaimana hukum-hukum yang ditetapkan dalam perundang-undangan, yang notabene mengadopsi hukum Barat, apakah harus ditaati sebagaimana hukum syariat? Undang-Undang nasional disusun tidak terlepas dari ajaran agama, oleh karenanya pada tahun 1974, hukum Islam tentang perkawinan masuk pada Undang- 
undang Nomor 1 tahun 1974. Pada tahun 1989, hukum Islam kembali mendapat penguatan dengan ditetapkannya Undang-undang Nomor 7 Tahun 1989 tentang Peradilan Agama. Setelah itu, berbagai materi hukum Islam dimasukkan ke dalam komponen hukum nasional, dengan dibuatnya undang-undang mengenai zakat, wakaf, haji, bank syariah dan masalah pornoaksi serta pornografi.

Dengan kata lain, proses penetapan undang-undang yang mengatur kehidupan warga negara Indonesia termasuk di dalamnya hubungan muamalah, mengakomodasi aturan-aturan agama Islam. Yang penting untuk dipahami adalah ajaran agama, dalam hal ini syariat sebagai norma yang menjadi pedoman bagi umat Islam dalam menjalani kehidupannya. Dengan kata lain, bahwa nilai-nilai yang terkandung dalam ajaran Islam bisa diterapkan dalam hukum perundang-undangan yang disesuaikan dengan kondisi masyarakat sesuai dengan metodologi pendekatan fikih.

Oleh karenanya, usaha untuk memasukkan nilai-nilai syariat ke dalam sistem hukum nasional merupakan ikhtiar untuk menjadikan syariat sebagai nilai-nilai yang dapat berlaku konkret di masyarakat. Ikhtiar tersebut, dalam kenyataannya, terbukti efektif dengan memanfaatkan perangkat hukum yang berasal dari Barat.

Dari penjelasan di atas, maka penafsiran ayat yang tidak menegakkan hukum Allah dikatakan kafir, implikasinya adalah keluar dari agama Islam. Ibnu Kasiir dalam tafsir al-Quran al Ažim menjelaskan bahwa, makna kafir dalam surat al-Maidah ayat 44 bukan berarti keluar dari agama. Sebagaimana pendapat ulama berikut:

1. Abdullah bin Abbas

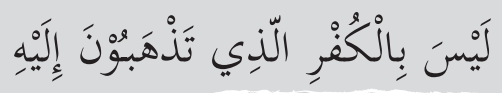

(Kufur yang dimaksud di dalam ayat itu) bukanlah kufur, yang kalian beralih (keyakinan) kepadanya. 
2. Ibnu Thawus

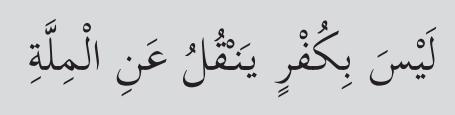

Makna kufur di dalam ayat itu, bukanlah kufur keluar dari agama (Islam)

Menurut M. Quraish Shihab, terma "kafir" dalam al-Quran disebut sebanyak 525 kali, yang mana tidak semua maknanya kemudian dikatakan keluar dari millah (agama). Dalam Tafsir al-Misbah dijelaskan bahwa pada surah al Maidah ayat 44, yang dimaksudkan kafir adalah mengingkari keesaan Allah. Hal senada diutarakan oleh Syaikh Ramadhan al-Buthy yang menyebut kata "kafir" yang dimaknai keluar dari Islam adalah ketika seorang muslim menolak dan mengingkari keberadaan syariat yang berlaku atas dirinya.

Singkatnya, pemaknaan "Hukum hanya milik Tuhan" tidaklah mutlak, baik dikaji secara historis, tafsir maupun pendekatan fikih. Untuk menegakkan hukum Allah, maka harus kembali kepada syariat, untuk menetapkan syariat maka tidak terlepas dari 'Urf serta maslahah. Undang-undang yang berlaku mengenai Hukum Islam di Indonesia tidak terlepas dari nilai-nilai syariah. Selanjutnya mengenai kekafiran orang yang tidak menegakkan "Hukum Allah" sebagaimana pendapat-pendapat para ulama di atas, setidaknya cukup untuk dijadikan argumen bahwa orang yang tidak menetapkan hukum Islam, tidak lantas dikatakan kafir sebagaimana keluar dari ajaran Islam. 


\section{Haramnya Ziarah Kubur}

Dalam beberapa ceramah keagamaan serta pengajian-pengajian, ziarah kubur adalah salah satu tema yang sering diperbincangkan. Tak jarang tema mengenai ziarah kubur dimasukkan ke dalam kategori perbuatan bid'ah bahkan dikatakan sebagai perbuatan syirik. Istilah populer yang sering dilontarkan adalah "kuburiyyun" (penyembah kubur) yang ditujukan kepada mereka yang melakukan ziarah kubur.

Pengharaman ziarah kubur didasarkan kepada hadis riwayat Abu Hurairah yang menjelaskan bahwa Rasulullah Saw. melaknat perempuan yang berziarah kubur.

$$
\text { لَعَنَ زَوََّارَاتِ القُبْورِ }
$$

Rasūlullāh Saw. melaknat para perempuan yang berziarah kubur.

Pengharaman ini dikiaskan atau dianalogikan dengan menyembah kuburan. Argumentasi yang digunakan adalah hadis yang diriwayatkan oleh Ahmad dari Ibnu Mas'ud:

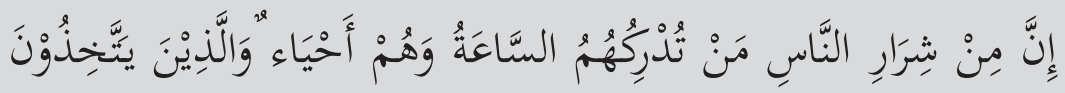

$$
\begin{aligned}
& \text { الْقُبْورَ مَسَساجِحَ }
\end{aligned}
$$

Sungguh termasuk kelompok manusia yang buruk (keadaannya) adalah orang yang hidup pada saat terjadinya kiamat dan orang yang menjadikan kuburan sebagai masjid.

Pengharaman ziarah kubur tidak hanya dialamatkan kepada kaum wanita, tetapi juga praktik ziarah kepada makam Nabi Muhammad SAW, sebagaimana doa yang Rasulullah panjatkan sebelum wafatnya dalam kitab at-Tauhid karya Sholih bin Fauzan. 


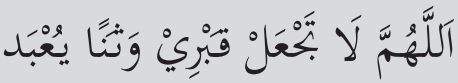

Ya Allah, jangan Engkau jadikan kuburku sebagai berhala yang disembah.

Argumentasi lain yang dijadikan dasar pengharaman ziarah ke makam Rasulullah sebagaimana yang diutarakan oleh Ibnu Taimiyyah di dalam kitabnya, "Iqtidho'u Shirāt al-Mustaqim" adalah berdoa di depan makam Nabi, termasuk ke dalam perbuatan menjadikan makam Rasulullah sebagai i'ed (tempat hari raya). Menurutnya, perbuatan tersebut masuk ke dalam larangan yang ditegaskan Rasulullah Saw.,

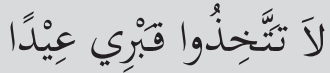

Jangan kalian jadikan kuburku sebagai tempat hari raya.

Lantas bagaimana, dengan hadis yang menyatakan anjuran berziarah kubur? Dan bagaimana Islam memandang ziarah kubur bagi para perempuan?

Untuk menjawab pertanyaan serta menyanggah argumen pengharaman ziarah kubur tidak terlepas dari konteks sejarah.

Ziarah kubur merupakan perbuatan yang dianjurkan dalam Islam. Dalam sebuah hadis yang diriwayatkan oleh Imam Ahmad ra., Rasulullah Saw. bersabda:

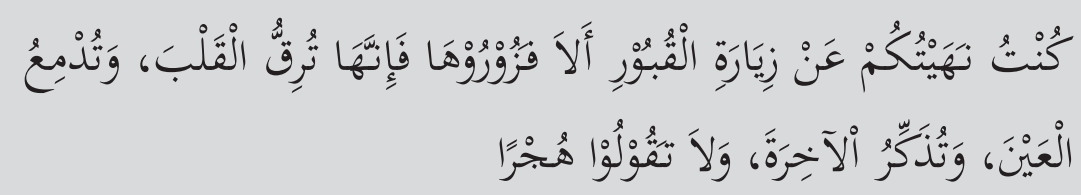


Aku pernah melarang kalian untuk ziarah kubur, sekarang ziarahilah kubur karena ziarah kubur dapat melembutkan hati, meneteskan air mata, mengingatkan akhirat dan janganlah kalian mengucapkan kata-kata kotor (di dalamnya)."

Dalam hadis lain riwayat Ibnu Majah ra., Rasulullah Saw. bersabda:

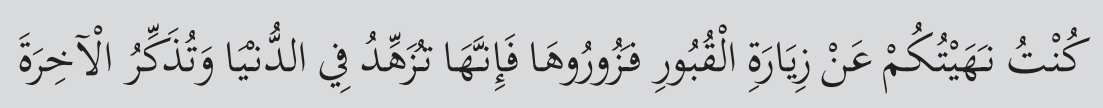

(Dulu) Aku melarang kalian berziarah kubur, maka (sekarang) berziarahlah kalian ke kuburan, sesungguhnya ziarah kubur membuat kalian zuhud di dunia dan mengingatkan kalian pada akhirat.

Rasulullah Saw. sendiri melakukan ziarah kubur ke makam ibunya Siti Aminah di Abua, sebagaimana yang diriwayatkan oleh Abu Hurairoh, dalam Șahih Muslim;

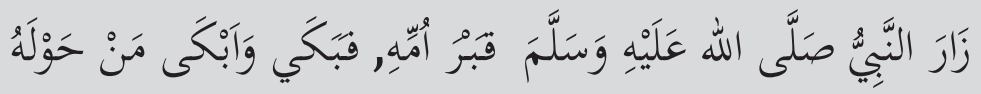

Nabi SAW ziarah ke makam ibunya kemudian menangis Ialu menangislah orang-orang di sekitarnya.

Hadis-hadis di atas menginformasikan kepada kita bahwa ziarah kubur merupakan salah satu ritual ibadah yang awalnya diharamkan, lalu dibatalkan (mansukh) oleh Rasulullah Saw. menjadi suatu anjuran yang disunahkan untuk dilakukan.

Salah satu hikmah dari kesunahan dianjurkannya ziarah kubur adalah mengingat kematian. Mengingat kematian membuat kita hidup zuhud (berorientasi kepada akhirat), sehingga kita menjadi lebih waspada dalam 
menjalankan kehidupan dengan penuh pengharapan akan rida Allah Swt. Di samping itu, berziarah kubur dapat melembutkan hati, menyadarkan manusia bahwa kita tidak selamanya hidup di dunia, oleh karenanya berlomba-lombalah dalam melakukan kebaikan, karena hanya amal perbuatan baiklah yang kelak akan mengantarkan manusia ke alam kubur.

hadis tersebut juga menginformasikan kepada kita secara spesifik bahwa menangis di dekat kubur secara wajar, dalam artian tidak berlebih-lebihan hingga membahayakan diri sendiri dan membuat kekhawatiran bagi orang lain, tidaklah berimplikasi pada kekafiran, begitu juga tidak mendatangkan siksa bagi mayat yang ditangisi.

Adapun pendapat para ulama tentang ziarah kubur di antaranya:

\section{Imam Ahmad bin Hanbal}

Ibn Qudāmah dalam kitabnya "al-Mugni" menceritakan bahwa Imam Aḥmad ibn Hanbal pernah ditanya pendapatnya tentang masalah ziarah kubur, manakah yang lebih utama antara ziarah kubur ataukah meninggalkannya? Imam Ahmad kemudian menjawab, ziarah kubur itu lebih utama.

\section{Imam Nawawi}

Imam Nawawi secara konsisten berpendapat dengan hukum sunahnya ziarah kubur. Imam Nawawi juga menjelaskan tentang adanya ijma' dari kalangan Ashab as-Syafii (para pengikut Imam Syafii) tentang sunahnya ziarah kubur.

\section{Said Ramadlan al-Buthi}

Doktor Said Ramadhan al-Buthi juga bersepakat dengan pendapat yang memperbolehkan ziarah kubur.

\section{Muhammad Zakky Ibrahim}

Seorang tokoh tasawuf di Mesir, di dalam karyanya yang berjudul alMasyrū' wa al-Mamnū' fi Qadhāya al-Qubab memberikan penjelasan bahwa ziarah kubur merupakan perbuatan yang mempunyai dalil syariat (masyru'). Para ulama salaf sepakat mengenai anjuran untuk 
berziarah kubur didasarkan pada hadis Nabi Muhammad Saw. serta Nabi melakukan ziarah kubur ke pemakaman Baqi' dan mendoakan orang-orang yang dikuburkan di sana.

Mengenai larangan terhadap wanita untuk berziarah kubur, Syaikh Zakki Ibrahim menjelaskan bahwa Nabi mengizinkan puterinya Fatimah menziarahi makam Hamzah ibnu Abdul Muțallib di Uhud. Nabi juga mengijinkan Aisyah, istrinya, berziarah ke makam kakaknya Abdurrahman bin Abu Bakar. Bahkan Nabi mengajarkan apa saja yang perlu dibaca ketika berziarah kubur.

Dengan kata lain, bahwa berdasarkan tarjih (pengambilan dalil yang lebih kuat), maka pelarangan ziarah kubur bagi perempuan bukan bentuk pengharaman yang mutlak, dalam hadis-hadis lain terdapat anjuran bolehnya perempuan untuk berziarah kubur. Dalam keseluruhan hadis disebutkan bahwa anjuran ziarah kubur adalah umum, artinya; laki-laki dan perempuan. Adapun pelarangan yang dimaksud adalah jika ziarah kubur dilakukan secara berlebih-lebihan maka dalam hadis di atas disebutkan "sering mengunjungi kubur" yang kemudian lupa akan kewajibannya sebagai seorang istri. Dan larangan yang dimaksud adalah berlebih-lebihan dalam menangis, serta berpenampilan yang dapat menimbulkan fitnah.

Oleh karenanya, untuk menghindari hal tersebut, Islam mengajarkan adab atau tata cara dalam berziarah kubur. Sebagaimana yang diutarakan oleh Syaikh Zakki Ibrahim bahwa terdapat larangan dalam berziarah kubur, yakni; meminta sesuatu kepada mayat. Yang diperbolehkan adalah bertawassul kepada Allah dengan menyebut nama orang saleh, yang tujuannya adalah agar Allah mengabulkan permintaan orang yang berziarah.

Lebih lanjut Syaikh Zakki Ibrahim juga menjelaskan adab-adab yang harus diperhatikan ketika berziarah, yaitu:

1. Membangun kekhusyukan hati ketika berziarah;

2. Mengingat kematian di dalam hati;

3. Mengambil pelajaran dari peristiwa kematian;

4. Bersedekah atas nama mayat; 
5. Mendoakan mayat-mayat;

6. Membacakan al-Quran;

7. Menjaga kehormatan makam;

8. Menjaga kebersihannya;

9. Jangan sampai meninggalkan ziarah kubur atau melupakannya;

10. Jangan sampai kemewahan kubur membuat diri terlena sehingga melupakan mayat yang ada di dalam kubur;

Adab-adab dalam berziarah ini secara rinci dijelaskan dalam kitab Tafsir as-Sirāj al-Munir: Hendaknya bagi orang yang berziarah di kuburan untuk berperilaku sesuai dengan adab-adab ziarah kubur dan menghadirkan hatinya pada saat mendatangi kuburan. Tujuannya datang ke kuburan bukan hanya sebatas berkeliling saja, sebab perilaku ini adalah perilaku binatang. Tetapi tujuan ziarahnya karena untuk menggapai rida Allah Swt. memperbaiki keburukan hatinya, memberikan kemanfaatan pada mayat dengan membacakan di sisinya al-Quran dan doa-doa. Dan juga menjauhi duduk di atas kuburan, dan melangkahi kuburan.

Pertanyaan selanjutnya adalah, apakah pahala yang dibaca ketika berziarah sampai kepada mayat sebagaimana yang diutarakan oleh al-Buthi berkata; "Belakangan ini banyak dari kalangan umat Islam yang mengingkari sampainya pahala kepada mayat, dan menyepelekan permasalahan ziarah ke kubur."

Untuk menjawab pertanyan tersebut, Imam Nawawi berkata dalam kitabnya, al-Ażkar, "Para ulama sepakat bahwa doa pada orang yang meninggal, bermanfaat dan sampai pada mereka," diriwayatkan dari Nabi Muhammad Saw. bahwa sesungguhnya beliau bersabda:

"Tidak ada perumpamaan mayat di kuburnya kecuali seperti orang tenggelam yang ingin ditolong, mayat menunggu doa yang ditujukan padanya baik dari anaknya, saudaranya atapun temannya. Ketika doa itu telah tertuju padanya, maka doa itu lebih la cintai daripada dunia dan seisinya." 
Begitu pula dengan ziarah para wali atau orang saleh yang lebih popular dengan wisata religi, dengan membaca al-Quran, tawassul dan zikir-zikir, merupakan tradisi para salaf aṣ-ṣalih. Sebagaimana yang diutarakan oleh Ibn Hibban dalam aś-Siqat,

"Setiap aku mengalami kesulitan, selama tinggal di Thus, lalu aku berziarah ke makam Ali bin Musa al-Rido, dan aku berdoa kepada Allah agar menghilangkan kesulitan itu dariku, berkat wasilahnya doaku pasti dikabulkan. Hal itu berulang kali aku lakukan, dan selalu terbukti."

Pengakuan Ibnu Hibban, pengarang kitab Șaḥih ibn Hibban sekaligus memberikan informasi kepada kita bahwa ziarah kepada orang-orang saleh bukan berarti meminta kepada mayat, sebagaimana yang sering dilontarkan oleh kelompok yang mengharamkan ziarah kubur, dengan mengistilahkan "kuburiyyun" yakni para penyembah kubur. Yang diidentikkan dengan meminta-minta kepada mayat, melakukan ziarah kubur pada waktu-waktu tertentu, melakukan ibadah di dekat makam orang saleh, seperti membaca al-Quran dan salat, dan memuja-muja kuburan dengan bacaan salawat atau syair-syair.

Untuk menjawab argumentasi tersebut, perlu dipahami hal-hal sebagai berikut:

1. Para ulama termasuk dari kalangan sufi sepakat bahwa haram hukumnya meminta-minta kepada mayat. Berbeda halnya dengan ber-tawassul, yaitu berdoa kepada Allah dengan menyebut keutamaan orang saleh yang sudah wafat. Sejatinya, mereka berziarah bukan berarti menyembah dan meminta kepada mayat melainkan dalam bentuk tawassul sebagaimana dalil syar'i adanya anjuran untuk berziarah.

2. Di dalam praktiknya, perilaku para peziarah yang disebutkan sebagai "para penyembah kubur" tetap menjaga etika dan menjalankan adababab ziarah kubur yang berlaku.

3. Dalam kasus ziarah ke makam Rasul, setiap peziarah diharuskan untuk menjaga adab dan sopan santun, seolah-olah mereka sedang 
mendatangi Rasulullah dalam keadaan hidup; dengan kata lain, bahwa mengunjungi makan Rasulullah bukan merupakan perkara yang dilarang, ketika para Salafu salih berziarah dan ber-tawassul kepada orang saleh, tentunya Nabi Muhammad Saw. berada di posisi teratas yang layak untuk diziarahi.

4. Mengenai waktu berziarah. Syaikh Zakki Ibrahim menjelaskan tidak ada satu pun hadis yang menganjurkan atau melarang ziarah kubur pada waktu-waktu tertentu. Itu artinya ziarah dapat dilakukan kapan saja;

5. Adapun tentang kegiatan membaca al-Quran dan melakukan salat di kompleks pemakaman, para ulama telah membahas perkara ini secara panjang lebar dan tidak ada penolakan dari mereka kecuali dari lbnu Taimiyah dan pengikut-pengikutnya. Imam Syafii bahkan diriwayatkan melaksanakan salat di musala dekat makam Imam Abu Hanifah, dalam rangka tabarruk (mengambil keberkahan). Tentang membaca al-Quran di kompleks makam, Ibnu Qayyim Al-Jauziyyah memberikan penjelasan yang rinci tentang sampainya pahala membaca al-Quran kepada mayat, sebagaimana ditulis di dalam kitab al-Rūh.

Dapat disimpulkan bahwa ziarah kubur merupakan bentuk ritual atau ibadah yang berlandaskan pada syariat, dan disunahkan bagi laki-laki maupun perempuan. Dalam Islam terdapat larangan untuk berziarah kubur, yakni meminta kepada mayat. Yang diperbolehkan adalah tawassul. Hendaknya dalam berziarah memerhatikan adab-adab dalam berziarah kubur, sehingga tujuan dari ziarah untuk mengingat kematian dapat meresap ke dalam hati dan menjadi pribadi yang lebih baik dalam mempersiapkan kematian untuk menggapai rida Allah Swt. 


\section{Bersalaman dengan Lawan Jenis}

Dalam syariat Islam, pergaulan antara laki-laki dan perempuan bukan mahram diatur sedemikian rupa. Syariat menetapkan beberapa batasan dan tata krama mengenai hal tersebut guna menutup kemungkinan terciptanya dosa dan kerugian. Dari sana, syariat mengharamkan apa yang disebut dengan khalwat, yaitu keadaan di mana seorang laki-laki berduaan di tempat sepi bersama perempuan yang bukan mahramnya (memiliki ikatan darah dengan laki-laki tersebut yang haram dinikahinya). Khalwat dilarang dalam Islam karena dapat membangkitkan nafsu dan melakukan perbuatan-perbuatan yang dilarang agama seperti perbuatan zina.

Mengikuti aturan khalwat, tradisi yurisprudensi Islam atau fikih juga mengaturnya. Para ulama mazhab membahas aturan-aturan yang terdapat pada khalwat. Mereka membuat rincian mengenai hukum-hukumnya. Imam Nawawi misalnya, mengatakan bahwa yang disebut khalwat ialah berduaan dengan wanita atau lelaki asing (bukan mahram) tanpa kehadiran orang ketiga. Orang ketiga tersebut tidak termasuk anak kecil karena keberadaannya tidak dianggap.

Berangkat dari khalwat, para ulama fikih Islam mengatur hukum memandang kepada wanita asing bukan mahram. Hal sama terjadi pada hukum aurat wanita baik dalam salat maupun di luar salat. Berangkat dari hubungan-hubungan tersebut, fikih Islam juga memasukkan interaksi antara laki-laki dan wanita ke dalam rincian hukum ibadah tertentu.

Dalam hal wudu misalnya, bersentuhnya kulit laki-laki dan kulit wanita dapat membatalkan wudu. Hampir kebanyakan mazhab fikih menyatakan bahwa menyentuh kulit sesama jenis dapat membatalkan wudu.

Imam Malik berbeda dengan Syafii dan Ahmad bin Hanbal, baginya, persentuhan tersebut dapat membatalkan wudu dengan syarat adanya syahwat ketika bersentuhan. Apabila persetuhan itu tidak diiringi syahwat, wudunya tidak batal. As-Sarakhsi dalam al-Mabsut mengutip, "Malik ra. Berkata bahwa wudu wajib dilakukan kembali jika persentuhan terjadi dengan syahwat. Apabila tidak disertai syahwat, itu tidak wajib dilakukan." 
Bagi Mazhab Hanafi, menyentuh kulit wanita/laki-laki asing tidak membatalkan wudu secara mutlak, baik disertai syahwat maupun tidak. As-Sarakhsi mengatakan, "Wudu tidak wajib dilakukan karena mencium dan menyentuh wanita, baik dengan syahwat maupun tidak."

Berkaca dari Mazhab Hanafi, nampaknya bersentuhan kulit antara lawan jenis tidaklah menimbulkan masalah, khususnya terkait wudu dan salat. Dengan demikian, salat atau ibadah lainnya seperti thawaf tidak akan batal hanya dengan bersentuhan dengan lawan jenis. Adanya perbedaan dari Mazhab Hanafi terkait hal ini dapat dikembangkan kepada hukum menyentuh lawan jenis dalam bentuk berjabat tangan. Jika bersalaman masuk kategori "bersentuhan" tidak membatalkan wudu, setidaknya menurut Mazhab Hanafi, apakah itu merambat ke hukum lain seperti keharaman menyentuh wanita? Dalam tradisi Nabi (hadis), banyak riwayat yang menyebutkan bahwa menyentuh wanita ialah haram dan dilarang agama karena dapat menimbulkan syahwat yang dapat mendorong perbuatan zina.

Di antara dalil yang dijadikan landasan keharaman menyentuh wanita ialah redaksi yang berbunyi:

"Jika kepala kalian ditusuk oleh jarum dari besi, itu lebih baik dibandingkan menyentuh wanita yang tidak dihalalkan baginya." (HR. ath-Thabrani)

Riwayat ini berasal dari Syadad bin Sa'id yang terindikasi “lemah" dalam periwayatannya. Ini dikarenakan riwayat lain dengan redaksi berbeda juga berasal darinya, yaitu hadis yang berbunyi:

"Aku lebih menyukai kalian menusukkan jarum besi ke dalam kepalaku, dibandingkan kepalaku dibasuh seorang wanita yang bukan mahramku."

Kesalahan dalam lafal hadis dapat melemahkan hadis itu sendiri. Di samping itu, anggap saja sanad hadis keduanya benar, riwayat tersebut bukan membicarakan jabat tangan antar lawan jenis. Dalam tradisi bahasa Arab, kata "menyentuh" atau al-lams biasanya digunakan untuk menyebut 
aktivitas persetubuhan (jimak). Dengan begitu, "menyentuh" wanita bisa bermakna menyetubuhinya.

Mengenai hal itu, Ibnu Taimiyah memberikan komentar, "Siapa yang mengira bahwa ayat 'atau kalian menyentuh wanita' bermakna menyentuh kulit meski tanpa syahwat, maka ia telah keluar dari koridor bahasa yang dibawa al-Quran sendiri, bahkan keluar dari bahasa yang biasa digunakan manusia saat itu."

Dalil lain yang dijadikan landasan haramnya bersalaman dengan wanita non-mahram ialah riwayat yang berbunyi:

Tangan Rasulullah Saw. tidak pernah sekalipun menyentuh tangan wanita lain kecuali yang dimilikinya (mahram). [HR. al-Bukhari].

Juga riwayat yang terdapat dalam kitab al-Muwatța karya Malik, dari Umaimah binti Raqiqah:

"Sesungguhnya aku tidak bersalaman dengan para wanita."

Kedua riwayat tersebut meskipun mengindikasikan bahwa Rasulullah tidak menyentuh wanita, bukan berarti menujukkan keharaman berjabat tangan, karena keengganan Rasulullah Saw. terhadap sesuatu tanpa melarangnya bukan berarti sesuatu itu haram. Hal ini dibuktikan dengan keengganan Nabi untuk memakan bawang putih, bawang merah dan kadal gurun. Nabi memang tidak mau memakannya, tetapi ia tidak melarangnya untuk sahabat-sahabatnya.

Dari sini, hadis tersebut dapat dimaknai sebagai hukum "makruh" bersentuhan antara laki-laki dan wanita non-mahram yang disertai syahwat, bukan pengharaman mutlak terhadapnya. Meskipun begitu, ada beberapa riwayat yang juga dijadikan dasar kebolehan bersalaman dengan wanita bukan mahram, seperti hadis yang berbunyi:

Ketika seorang budak wanita Madinah menggenggam tangan Rasul, wanita itu membawanya ke mana pun yang ia mau. [HR al-Bukhari]. 
Bahkan terdapat tambahan redaksi dari riwayat di atas, yang berasal dari Ahmad dan Ibnu Majah, "Dan Rasulullah Saw. tidak melepaskan tangannya dari tangan budak wanita itu."

Riwayat ini dianggap baik oleh al-Albani dalam Șāhih ibnu Majah (no. 4177) meskipun terdapat perawi yang dilemahkan dalam sanadnya, yaitu Ali bin Zaid bin Jad'an.

Riwayat lain juga berasal dari Bukhari muslim, dari Anas ra., bahwasanya Rasulullah Saw. pernah masuk ke dalam rumahnya Ummu Haram binti Milhan dan ia memberinya makan. Ummu Haram sendiri merupakan istri dari Ubadah bin Shamit. Saat itu, Ummu Haram menelisik (memijat kepala atau menghilangkan kutu) di kepala Nabi sampai Nabi tertidur dan tertawa setelah terbangun.

Ummu Haram sendiri bukan termasuk mahramnya Rasulullah Saw., seperti yang ditegaskan oleh Ibnu Hajar al-Asqalani dalam Fath al-Bari. Ada juga yang menganggap bahwa kejadian tersebut hanya dikhususkan untuk Nabi dan tidak boleh dilakukan oleh orang selainnya.

Klaim ini dibantah oleh ulama besar seperti Hakim lyadh yang mengatakan bahwa pengkhususan (terhadap Nabi) tidak dapat terjadi jika dalilnya masih berupa kemungkinan (muhtamal). Hal ini ditegaskan oleh riwayat lain dalam Șaḥịh al-Bukhari yang menyebutkan bahwa Abu Musa al-Asy'ari, seorang sahabat Nabi, pernah ditelisik kepalanya (dipijit) oleh seorang wanita dari Bani Asy'ari yang saat itu bukan mahramnya.

Kesimpulan yang dapat ditarik dari perdebatan mengenai hukum jabat tangan atau bersalaman, ialah kenyataan bahwa masih terdapat perbedaan pendapat mengenai hal tersebut sehingga hukum mengenainya tidak dapat dikatakan telah mencapai konsensus. Jika demikian, hadis-hadis dan riwayat yang menyebutkannya dapat dimaknai sebagai larangan makruh, bukan pengharaman. Bersalaman dimakruhkan jika dapat mendatangkan fitnah (godaan), dan hal itu bukan berarti pengharaman, melainkan sebatas "mencegah kemungkinan yang buruk" atau bahasa uṣūl al-fiqh menyebutnya sadd aż-żari'ah. 


\section{Aurat Perempuan}

al-Quran sebagai sumber hukum Islam selalu mengajarkan penerapan hukum Islam yang hakiki, yang menjadi rahmat bagi seluruh umat manusia. Hakikat itu sendiri menjadi prinsip penegakan hukum Islam di mana pun berada. Dalam hakikat hukum Islam, kemaslahatan menjadi titik terakhir sebagai tujuan hukum Islam. Salah satunya adalah tentang berpakaian yang menjadi salah satu ciri peradaban manusia sebagai makhluk terhormat. Pakaian sebagai sebuah busana merupakan mode dan kebutuhan manusia yang hakiki, yang selalu berkelindan dengan perkembangan zaman dan tradisi yang ada. Ia mengalami daur ulang dan berputar mengikuti roda zaman.

Di era modern ini, fashion berkembang dengan sangat cepat, begitu juga dengan model pakaian danjilbab, sampai bahan yang digunakan mengalami perubahan yang terus meningkat. Mode berpakaian terus berkembang, mulai dari yang terbuka sampai yang tertutup tetapi memperlihatkan kemolekan tubuh, sampai tertutup tanpa menyisakan celah sedikitpun. Terkait dengan ini, Islam sebagai agama yang sempurna sejak awal memperhatikan perkembangan mode pakaian, serta memberikan prinsipprinsip hukum dan aturan yang detail terkait dengan cara dan penggunaan pakaian. Apalagi yang berkaitan dengan perempuan.

Dewasa ini, banyak kita jumpai wanita yang keluar rumah tanpa menggunakan jilbab, bahkan mengumbar auratnya dengan menggunakan pakaian yang serba minim. Di era millenial ini hal-hal semacam itu dianggap biasa-biasa saja, bahkan seakan-akan menutup aurat itu bukan kewajiban dan membuka aurat itu tidak berdosa. Mereka tidak menyadari bahwa mengumbar aurat merupakan sebuah kemaksiatan yang perlu dihindari. Bahkan sebaliknya, orang yang menutup aurat dianggap kurang gaul dan kurang mengikuti tren fashion. Inilah fakta yang terjadi di kalangan para wanita modern saat ini. Mengapa hal itu bisa terjadi, ini merupakan suatu problem yang perlu dikaji dan diuraikan secara rinci, agar para wanita muslimah mampu memahami secara komprehensif. Karena dalam Islam, 
menjaga aurat termasuk hal mendasar dan wajib ditaati. Jika dilanggar maka termasuk mengingkari syariat Islam dan dapat dikategorikan sebagai perbuatan yang melanggar syariat.

Sebelum membahas lebih jauh, kita perlu mengetahui pengertian aurat. Aurat berasal dari bahasa Arab "awra" yang merupakan bentuk jamak dari Aurat. Secara bahasa, Aurat merupakan tempat yang paling tersembunyi dan rahasia, sedangkan "awra" bermakna bagian dari manusia yang wajib disembunyikan. Yang wajib disembunyikan di sini dapat diartikan sebagai segala sesuatu (area tubuh manusia) yang dapat menyebabkan rasa malu bila terlihat oleh orang lain. Hal tersebut berdasarkan pada kitab Ibn Manzur berjudul Lisan al-Arab.

Sedangkan menurut terminologi fikih Islam, aurat diartikan sebagai daerah atau bagian tubuh manusia yang wajib ditutupi dari pandangan orang lain dengan pakaian yang sesuai syariat Islam. Dan menjaga aurat wajib hukumnya untuk dipatuhi, sebagaimana yang telah diterangkan dalam al-Quran.

Beberapa ayat al-Quran yang membahas aurat di antaranya adalah surah al-Aḩzab ayat 59 dan surah an-Nur ayat 31;

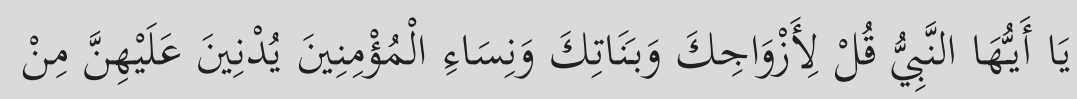

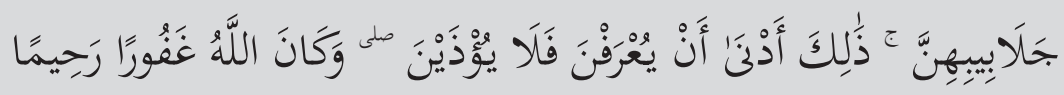

Hai Nabi, katakanlah kepada istri-istrimu, anak-anak perempuanmu dan istriistri orang Mukmin: "Hendaklah mereka mengulurkan jilbabnya ke seluruh tubuh mereka". Yang demikian itu supaya mereka lebih mudah untuk dikenal, karena itu mereka tidak diganggu. Dan Allah adalah Maha Pengampun lagi Maha Penyayang. [QS al-Ahzab: 59] 


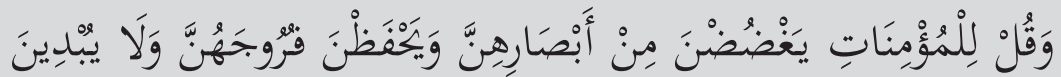

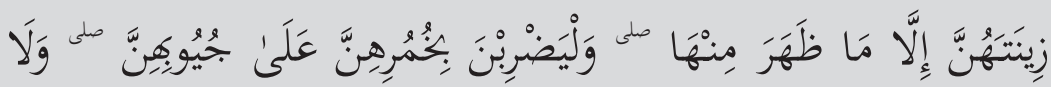

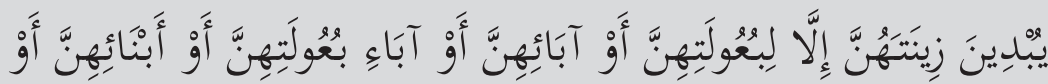

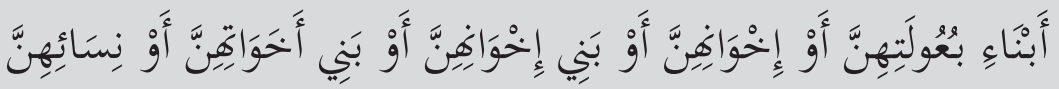

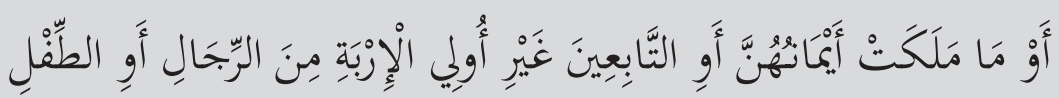

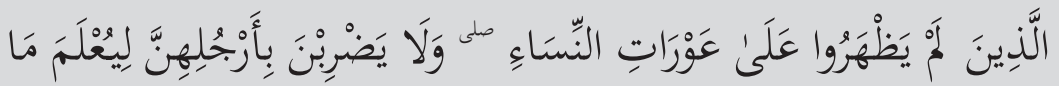

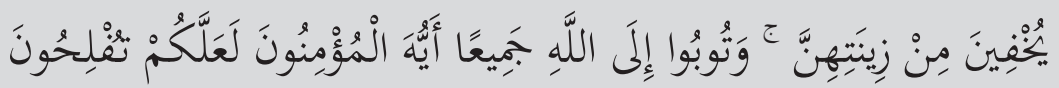

Katakanlah kepada wanita yang beriman: "Hendaklah mereka menahan pandangannya, dan kemaluannya, dan janganlah mereka menampakkan perhiasannya, kecuali yang (biasa) tampak dari padanya. Dan hendaklah mereka menutupkan kain kudung ke dadanya, dan janganlah menampakkan perhiasannya kecuali kepada suami mereka, atau ayah mereka, atau ayah suami mereka, atau putra-putra mereka, atau putra-putra suami mereka, atau saudara-saudara laki-laki mereka, atau putra-putra saudara lelaki mereka, atau putra-putra saudara perempuan mereka, atau wanita-wanita Islam, atau budak-budak yang mereka miliki, atau pelayan-pelayan laki-laki yang tidak mempunyai keinginan (terhadap wanita) atau anak-anak yang belum mengerti tentang aurat wanita. Dan janganlah mereka memukulkan kakinya agar diketahui perhiasan yang mereka sembunyikan. Dan bertaubatlah kamu sekalian kepada Allah, hai orang-orang yang beriman supaya kamu beruntung. [QS an-Nur: 31]

Dari penjelasan ayat di atas, bisa dipahami bahwa semua wanita memiliki kewajiban menutup aurat, yang mana ayat tersebut bukan hanya ditujukan kepada istri-istri Rasulullah, akan tetapi juga kepada istri-istri orang 
mukmin. Sehingga ini merupakan salah satu dalil dari beberapa ayat yang ada di dalam al-Quran terkait dengan kewajiban menutup aurat bagi para wanita Muslimah.

Setelah membahas tentang kewajiban menutup aurat bagi wanita Muslimah, selanjutnya yang perlu dipahami adalah batasan-batasan aurat bagi wanita yang harus diketahui. Para ahli hukum Islam berbeda pendapat dalam menentukan batasan-batasan aurat pada wanita, ada sebagian ulama yang berpendapat bahwa aurat wanita adalah seluruh anggota tubuh kecuali wajah dan kedua telapak tangan. Ada juga sebagian ulama yang berpendapat bahwa ulama wanita adalah seluruh anggota badan kecuali wajah.

Menurut pendapat yang paling rājih di kalangan ulama Hanafi, aurat wanita adalah seluruh anggota tubuh hingga sampai rambutnya yang terurai, kecuali wajah, kedua telapak tangan, dan kedua telapak kaki (pergelangan hingga ujung kaki), baik bagian luar telapak kaki atau telapak kaki bagian dalamnya. Sedangkan menurut Mazhab Syafii, aurat wanita adalah seluruh anggota tubuh kecuali wajah dan kedua telapak tangan. Menurut Mazhab Hambali aurat wanita adalah seluruh tubuh kecuali wajah. Sedangkan menurut Mazhab Maliki aurat terdiri dari seluruh tubuh kecuali muka dan kedua telapak tangannya.

Sedangkan aurat wanita saat salat terdiri dari seluruh tubuh kecuali bagian wajah, tangan, dan kaki. Jadi, wajib bagi seorang wanita yang pada saat salat harus menutupi tubuhnya dengan baik, yaitu menutupi seluruh bagian anggota tubuh kecuali wajah, tangan dan kaki. Bagian wajah wajib ditutupi dengan benar yaitu tidak ada rambut yang terlihat barang satu helai pun. Selain itu, bagian atas pergelangan tangan dan pergelangan kaki juga tidak boleh terlihat.

Dalam kitab Marāāi al-Falāh halaman 210 diterangkan juga bahwa ketika melakukan salat, wanita wajib menutupi auratnya dengan baik tanpa ada orang lain yang hadir atau sebaliknya, dan terlepas dari apakah wanita tersebut menjalankan kewajiban salat dalam cahaya terang ataupun dalam 
keadaan gelap. Menurut kitab Marāāi al-Falāh halaman 58, dijelaskan lebih rinci; untuk area di bawah dagu, batas aurat wanita saat salat dimulai dari titik di mana garis rambut biasanya tumbuh hingga bawah dagu, serta luasnya bagian antara kedua telinga.

Setelah mengetahui batasan-batasan aurat wanita dalam salat, sekarang kita bahas cara berpakaian yang sesuai dengan syariat Islam maksimal.

Adapun tips cara berpakaian yang benar menurut syariat Islam adalah sebagai berikut ini;

\section{Menutup aurat kecuali yang memang biasa terlihat}

Sesuai dengan penjelasan terkait batasan-batasan aurat wanita, Dalam hal ini wanita harus menggunakan pakaian yang panjang dan menutupi bagian anggota tubuh yang harus ditutupi kecuali wajah dan kedua telapak tangan. Hal ini sesuai dengan firman Allah Swt. dalam surah al-Ahzab ayat 59.

\section{Menggunakan pakaian yang longgar}

Menutup aurat haruslah maksimal, artinya tutuplah dengan kain yang benar-benar bisa menutupi tanpa meninggalkan celah sedikitpun. Karena meskipun pakaian yang dikenakan telah menutupi aurat tapi masih terlihat lekuk tubuhnya, hal tersebut akan bisa memancing syahwat laki-laki yang melihatnya. Islam juga mewajibkan wanita untuk menggunakan pakaian yang longgar dan hal ini sejalan dengan ilmu kesehatan yang menganjurkan untuk mengenakan pakaian longgar, hal ini bertujuan agar tubuh kita memiliki ruang gerak yang bebas dan leluasa.

\section{Berpakaianlah yang sederhana dan tidak menyerupai laki-laki} Islam sangat membenci penyakit hati seperti iri, dengki, dan sombong. Oleh karena itu cara berpakaian yang benar secara Islam haruslah dengan cara yang sederhana saja. Karena apabila wanita memakai pakaian yang berlebihan atau terlalu mencolok, maka akan lebih mudah menarik perhatian pandangan lawan jenis dan juga dapat menimbulkan penyakit hati seperti yang telah disebutkan sebelumnya. 
Secara tegas Islam melaknat perempuan yang berpenampilan seperti laki-laki, begitupun sebaliknya. Hal ini dijelaskan secara gamblang dalam dua hadis, yaitu riwayat dari Ibnu Abbas dan Abu Hurairah yang berbunyi,

"Rasulullah Saw. akan melaknat pria yang memakai pakaian wanita dan wanita yang memakai pakaian pria."

Sebagai generasi muslimah millenial, tentunya kita harus mampu membedakan pakaian-pakaian mana yang seharusnya kita kenakan, yang bisa menutupi aurat kita. Jangan hanya mengikuti tren fashion saat ini tetapi melupakan ajaran Islam yang mewajibkan seorang wanita muslimah untuk menutup aurat agar tidak menarik perhatian lawan jenis. Waalahu a'lam. 



\section{BAB LIMA}

\section{MENJAWAB POKOK MASALAH SIYASAH}

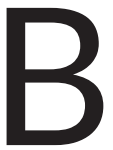

agian ini mengulas soal aspek politik atau hal-hal yang disangkutpautkan dengan politik dan Islam. Yang menjadi tema sentral dalam pembahasan ini adalah bagaimana relasi Islam dengan negara, berikut isu yang menjadi turunannya. Karena itulah, bagian ini mengulas tentang 6 pokok masalah: Mengenal Konsep Khilafah beserta model-model khilafah, Indonesia sebagai khilafah, mungkinkah? Apakah demokrasi haram, bagaimana hukum mencintai negara, dan terakhir bagaimana hukum hormat bendera merah putih.

\section{Mengenal Konsep dan Model Khilafah}

Wacana untuk menyatukan seluruh entitas umat Islam dalam kepemimpinan tunggal di bawah naungan sistem Khiläfah Islamiyah 
sebenarnya telah muncul setelah tumbangnya kekhalifahan Turki Usmani (1299 H/1923 M). Seiring perjalanan waktu, wacana tersebut terus bergulir dan cenderung semakin menguat. Argumen yang digunakan juga beragam. Namun, tulisan ini tidak hendak menyuguhkan semua pendapat yang beredar di kalangan mereka, melainkan hanya akan menghadirkan hal-hal yang sering digunakan dan dianggap sebagai argumen inti

Argumen yang paling mendasar di balik ide untuk mendirikan khiläfah Islamiyah adalah memberlakukan syariat Islam dalam setiap lini kehidupan, atau dengan kata lain menegakkan syariat Islam secara kaffah. Dalam pandangan mereka, cita-cita luhur untuk memberlakukan syariat Islam secara kaffah tidaklah mungkin dapat diwujudkan tanpa mendirikan khiläfah Islamiyah. Karenanya, mendirikan khiläfah islamiyah adalah sebuah kewajiban.

Rujukan mereka adalah praktik yang dilakukan oleh Rasulullah Saw. sendiri dengan mendirikan negara Madinah. Dalam konteks ini, Rasulullah Saw. memiliki peran ganda, yaitu sebagai seorang Nabi yang membawa syariat Islam dan sebagai pimpinan politik. Sebagai Nabi, keberadaan Nabi Muhammad sudah final. Sebagai pembawa syariat, tentu posisi Rasulullah tidak mungkin tergantikan.

Menjadi isu adalah posisi Nabi sebagai pemimpin politik. Keberhasilan Rasulullah Saw. sebagai pemimpin tunggal dan berhasil menyatukan seluruh entitas umat dalam wadah yang kemudian hari dikenal sebagai negara Madinah inilah yang menjadi contoh paling ideal, sehingga menjadi rujukan banyak kalangan. Persoalannya, ketika Nabi wafat, berarti generasi setelahnya memiliki mandat untuk menjaga setiap ajaran yang dibawanya. Dari sinilah kemudian tampil Abu Bakar ra. sebagai khalifah pertama, kemudian diteruskan Umar bin al-Khathab ra., Usman bin Affan ra., dan Ali bin Abi Thalib ra. Keempat khalifah tersebut kemudian dikenal dengan sebutan al-khulafa' ar-rasyidin.

Masa kepemimpinan Rasulullah Saw. dan keempat khalifah yang meneruskan estafet kepemimpinan beliau dan menjaga keberlangsungan 
syariat Islam adalah masa yang paling ideal dan sering dijadikan sebagai rujukan historis oleh para pegiat berdirinya khiläfah Islamiyah atau negara Islam.

Selain argumen historis di atas, gerakan penegak khiläfah Islamiyah juga mendasarkan argumentasinya kepada al-Quran. Di antaranya adalah ayat 48 dan 49 surah al-Maidah;

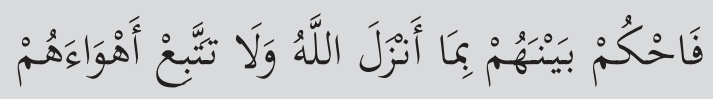

...maka putuskanlah perkara mereka menurut apa yang diturunkan Allah dan janganlah engkau mengikuti keinginan mereka... [QS al-Maidah: 48]

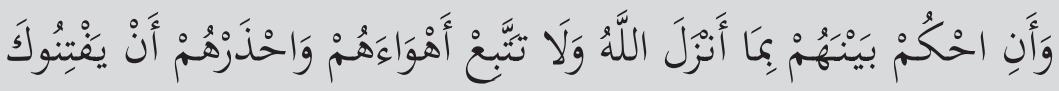

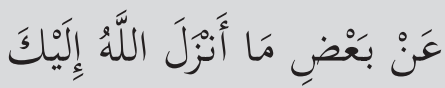

Dan hendaklah engkau memutuskan perkara di antara mereka menurut apa yang diturunkan Allah, dan janganlah engkau mengikuti keinginan mereka. Dan waspadalah terhadap mereka, jangan sampai mereka memperdaya engkau terhadap sebagian apa yang telah diturunkan Allah. [QS al-Maidah: 48]

Kedua ayat tersebut meskipun memerintahkan kepada Rasulullah Saw. untuk memutuskan hukum dengan apa yang diturunkan Allah Swt., tetapi perintah tersebut bersifat umum. Artinya perintah tersebut tidak hanya tertuju kepada Rasulullah Saw. tetapi juga kepada umatnya. Artinya, ayat di atas memerintahkan kepada segenap umat Muhammad tetap menjaga hukum-hukum Allah. Instrumen yang paling tepat dan efektif untuk melaksanakan perintah adalah dengan mendirikan pemerintahan khiläfah Islamiyah, di mana hukum-hukum Allah menjadi peraturan dalam bernegara. 
Selain teks al-Quran di atas, argumen lain yang digunakan adalah hadis Nabi yang berbunyi:

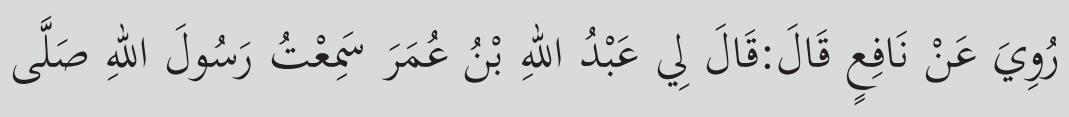

$$
\begin{aligned}
& \text { اللهُ عَلَيْهِه وَسَلَّمَ يَقُولُ مَنْ خَحَعَ يَدَا مِنْ طَاعَةِ لَقِىَ اللَّهَ يَوْمَ الْقِيَامَةِ وَلاً }
\end{aligned}
$$

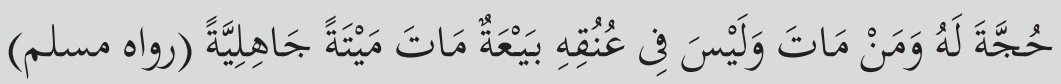

Diriwayatkan dari Nafi' ia berkata, Abdullah bin Umar ra. berkata kepadaku, saya telah mendengar Rasulullah Saw. bersabda, barang siapa yang melepaskan tangannya dari ketaatan, maka kelak pada hari kiamat akan bertemu Allah tanpa hujjah, dan barang siapa yang mati sedangkan tidak ada baiat pada pundaknya maka ia mati dalam keadaan mati jahiliah. [HR Muslim]

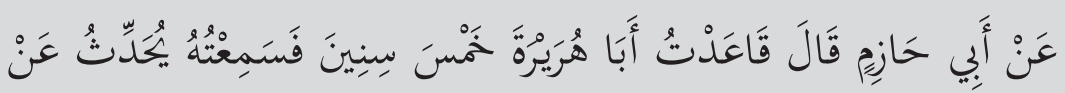

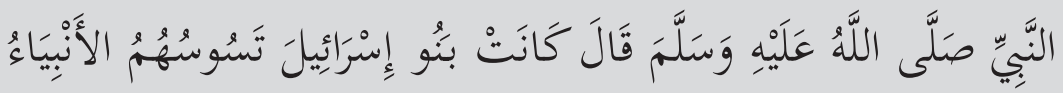

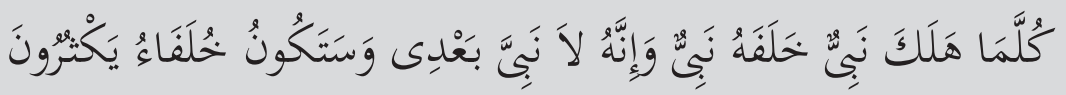

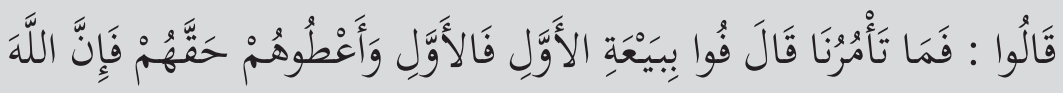

$$
\begin{aligned}
& \text { سَائلُهُهْمْ عَمَّنْ اسْترَعَاهُهْ (رواه البخاري ومسلم) }
\end{aligned}
$$

Dari Abu Hazim ia berkata, saya belajar kepada Abu Hurairah selama lima tahun, kemudian aku pernah mendengar ia menyampaikan hadis dari Nabi Saw. yang bersabda, Bani Israil telah dipimpin oleh para Nabi, ketika ada Nabi meninggal dunia, maka Nabi yang lain menggantikannya. Dan sungguh tidak ada Nabi setelahku, dan akan ada khalifah yang banyak. Mereka pun bertanya (kepada beliau), lantas, apa perintah engkau kepada kami? Nabi pun menjawab, penuhilah dengan membaiat yang pertama, kemudian yang pertama, dan 
berilah mereka apa yang menjadi haknya karena sesungguhnya Allah Swt. akan menanyakan kepada mereka tentang apa-apa yang menjadi tanggungjawab mereka". [HR Bukhari Muslim]

Hadis yang pertama menunjukkan dengan jelas kewajiban setiap muslim untuk membaiat seorang pemimpin. Dan pemimpin yang mereka maksudkan adalah seorang khalifah. Sedang hadis kedua menurut penggerak khiläfah Islamiyah menunjukkan dengan jelas bahwa kepemimpinan setelah Rasulullah Saw. diteruskan oleh para khalifah. Ini sesuai fakta sejarah, di samping itu hadis ini juga mengandung perintah untuk menaati khalifah. Karenanya, mendirikan khiläfah Islamiyah dan mengangkat khalifah adalah wajib.

Dari pemaparan ini dapat dipahami bahwa kekhilafāhan mengandaikan kepemimpinan tunggal karena sesuai praktik yang telah ada pada generasi awal. Untuk mendukung pandangan keharusan ketunggalan khalifah mereka mengajukan hadis-hadis yang melarang membaiat dua orang khalifah dalam waktu bersamaan. Di antaranya adalah hadis berikut ini:

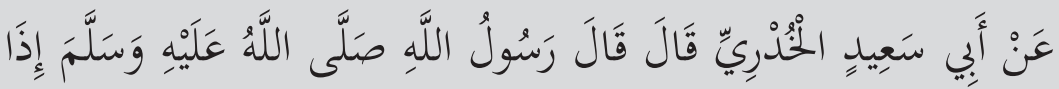

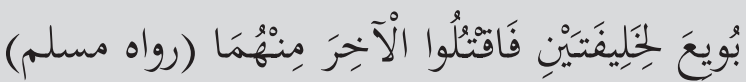

Dari Abi Said al-Khudri ra., ia berkata, Rasulullah Saw bersabda, apabila dibaiat dua orang khalifah maka bunuhlah yang terakhir di antara keduanya. [HR Muslim]

Dalil-dalil yang dikemukakan di atas itulah yang acapkali digunakan para aktivis pegiat Khiläfah Islamiyah untuk mendukung ide mereka. Lalu bagaimana kita mesti menyikapinya? 


\section{Makna Khilafah}

Dalam Lisānul Arab dijelaskan bahwa khilafah menurut bahasa adalah masdar dari kata khalafa yakhlifu khalifatan yaitu menggantikan, seperti khalafatuhu fi qawwamihi khilafatan (menggantikan seseorang dalam kaumnya). Tinjauan etimologi ini diambil dari surah al-A'raf ayat 142:

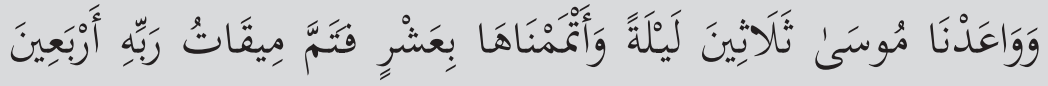

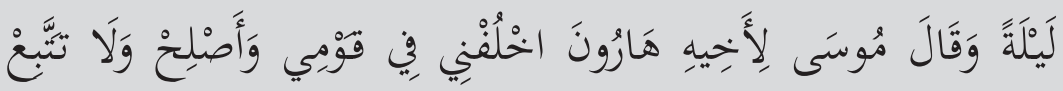

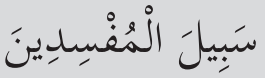

Dan telah Kami janjikan kepada Musa (memberikan Taurat) sesudah berlalu waktu tiga puluh malam, dan Kami sempurnakan jumlah malam itu dengan sepuluh (malam lagi), maka sempurnalah waktu yang telah ditentukan Tuhannya empat puluh malam. Dan berkata Musa kepada saudaranya yaitu Harun: "Gantikanlah aku dalam (memimpin) kaumku, dan perbaikilah, dan janganlah kamu mengikuti jalan orang-orang yang membuat kerusakan. . [QS al-A'raf :142]

Menurut istilah yang populer di kalangan umat Islam, khalifah adalah orang yang datang kemudian dan posisinya menggantikan orang sebelumnya, baik yang digantikannya masih ada maupun sudah tidak ada (Ali Abd alRaziq, 1972). Gelar ini pertama kali muncul dan disematkan kepada Abu Bakar pasca pelantikannya oleh umat Islam untuk menjabat kepemimpinan setelah wafatnya Nabi. Dari sini istilah khalifah membentuk makna sebuah institusi kepemimpinan pengganti Nabi.

Terdapat varian kata yang memiliki makna yang serupa dengan kata khalifah. Yakni kata imam. Secara bahasa, imam berarti orang yang diikuti dan diteladani. Kata imam lebih banyak digunakan untuk orang yang membawa kebaikan. Di samping sering dikaitkan dengan salat. Dalam 
kepustakaan Islam sering dibedakan antara imam yang berkedudukan sebagai kepala negara atau yang memimpin umat Islam dan imam dalam arti yang mengimami salat (Dzajuli, 2000).

Kata lain yang semakna dengan imam dan khalifah adalah amir al-mukminin, suatu gelar yang pertama kali disematkan kepada Umar bin Khatab, juga sultan dan malik (raja). Ulama Ahl as-Sunnah menyamakan pengertian imamah dan khalifah. Kedua definisi ini menjelaskan bahwa para ulama mendahulukan masalah-masalah agama dan memelihara agama daripada persoalan duniawi. Hal ini diperlukan untuk membedakan antara lembaga imamah atau khilafah dengan lembaga-lembaga yang lainnya (Dzajuli, 2000).

Secara istilah konsep khilafah seperti yang dikemukakan oleh beberapa ulama di antaranya Ibn Taimiyah. Menurut Ibn Taimiyah masalah istilah suatu negara apakah dengan menggunakan istilah Imamah atau Khilafah tidaklah menjadi hal yang substansial tetapi yang paling terpenting adalah terlaksananya Syariat Islam di negara tersebut. Ibnu Taimiyah (1969) memandang praktik pemerintahan Islam harus berorientasi pada dua hal: memelihara eksistensi agama dan mengatur strategi keduniaan. Ibnu Khaldun juga menyebut khilafah sebagai institusi kepemimpinan umum yang bertugas mengantarkan manusia pada kemaslahatan dunia dan akhirat. Ibnu Khaldun meletakkan syariat sebagai asas yang membedakan institusi khilafah dengan lembaga pemerintahan lainnya (Ibn Khaldun, t.th).

Definisi di atas senada dengan al-Mawardi (1989) yang menyatakan bahwa khilafah merupakan sebuah topik bagi institusi kekhalifahan dan nubuwwah yang bertugas memelihara agama dan mengatur dunia. Karena itu, menyelenggarakan kekhilafahan adalah wajib atas seluruh umat Islam.

Berdasarkan definisi di atas, setidaknya seorang menurut Shalah al-Sawi dalam Al-Wajiz fi Fiqh al-Khilafah, khalifah memegang tiga peranan penting. Pertama sebagai pengganti Nabi untuk menegakkan agama dan mengatur urusan-urusan manusia sesuai dengan kehendak agama. Kedua, memiliki tanggung jawab memelihara eksistensi agama serta mengatur strategi 
keduniaan. Ketiga, mencakup satu wilayah umum yang meliputi urusanurusan agama dan dunia, yang pemerintahannya mencakup keseluruhan umat manusia, sehingga tidak satupun umat Islam yang keluar dari pemerintahan imamah tanpa kecuali.

Konsep dasar khilafah yang telah ada selama ratusan tahun lamanya dan diadopsi oleh para pakar politik Islam serta dianggap sebuah kerangka baku bagi konstruksi dasar bernegara ternyata dewasa ini relatif tidak dapat diterapkan, setidaknya karena dua alasan; pertama, Islam tidak lagi memiliki lembaga politik yang berwenang menaungi seluruh kebutuhan-kebutuhan hidup dan kepentingan umat Islam sejak runtuhnya kekhalifahan Turki Usmani pada tahun 1924. Di samping itu, umat Islam kini hidup dan tersebar di berbagai wilayah, terutama sejak dideklarasikannya negara bangsa (nation state).

Kedua, warisan teori-teori khilafah dalam kitab-kitab klasik yang sarat dengan Arabisme dan fanatisme kesukuan sebagai asas berdirinya khilafah Islam. Itu berarti, teori-teori khilafah sendiri secara langsung bertentangan dengan prinsip-prinsip universal Islam (Mabadi al-ammah) yang sejak awal diperkenalkan Nabi kepada umat manusia, yang meliputi kesetaraan (alMusawah), keadilan (al-Adalah), persaudaraan humanisme (al-Ukhuwah bashariyah) dan sebagainya.

Teks syariat yang terkait dengan persoalan politik Islam, bagi sebagian kalangan, tidak lagi membuka ruang baru bagi perubahan-perubahan prinsipil mengenai konsep-konsep pemerintahan. Perubahan merupakan keniscayaan yang harus dihadapi umat. Mempertahankan teori-teori khilafah masa lalu yang terbentuk akibat dinamika sosial yang tidak inheren dengan kondisi saat ini yang juga akan merusak fleksibilitas Islam yang salih li kulli zaman wa makan (relevan, jauh melampaui batas ruang dan waktu).

\section{Model-Model Khalifah}

Seringkali kita menduga bahwa ketika menyebut kata khilafah Islam berarti mengandaikan adanya sistem politik yang tunggal, solid, komprehensif dan 
final. Padahal, jika kita menelusuri sejarah Islam, tidak ada sistem baku dalam kekhalifaan. Berikut beberapa model khilafah yang terjadi pada masa khulafā ar-rasyidin.

\section{Model Khilafah Abu Bakar (632-634 M)}

Setelah Rasulullah wafat, terjadi sengketa yang cukup besar perihal siapa yang akan menggantikan Rasulullah sebagai pemimpin politik dan pemimpin agama sekaligus. Pada saat itu, orang-orang Anshor berkumpul di Tsaqifah (balai pertemuan) Bani Sa'idah dan berencana mengangkat Sa'd bin Ubadah sebagai pemimpin setelah Nabi.

Kegaduhan di ruang pertemuan ini pun sampai terdengar ke telinga Abu Bakar dan Umar bin Khattab, dan keduanya bersama orangorang muhajirin mendatangi forum pertemuan tersebut. Terjadilah diskusi yang cukup alot, dan tiba-tiba salah satu dari kelompok Anshor dengan lantang berkata (sebagaimana yang dikemukakan oleh Umar bin Khattab):

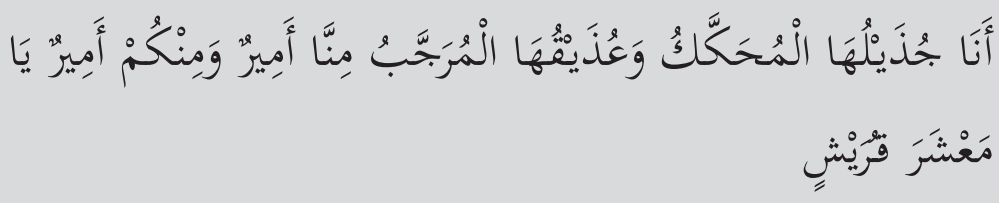

"Akulah sebagai orang yang dimintai pendapatnya dan mendukung kaumnya, dari kami pemimpin sendiri dan dari kalian ada pemimpin sendiri, wahai orang-orang Quraisy"

Gara-gara inilah, muncul kegaduhan yang amat dahsyat. Untuk melerai kegaduhan tersebut, Umar bin Khattab meminta Abu Bakar mengulurkan tangannya untuk dibaiat menjadi khalifah, yang kemudian diikuti oleh orang-orang Muhajirin dan Anshor.

Setelah selesai dibaiat menjadi khalifah pertama, Abu Bakar ra. melakukan orasi (khotbah) yang sangat terkenal: 


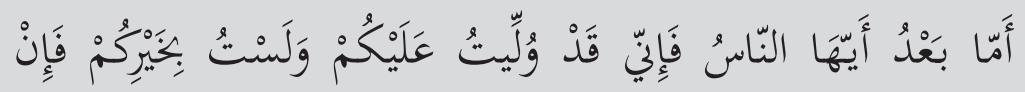

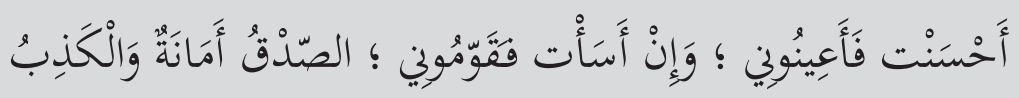

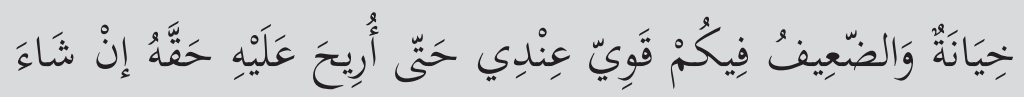

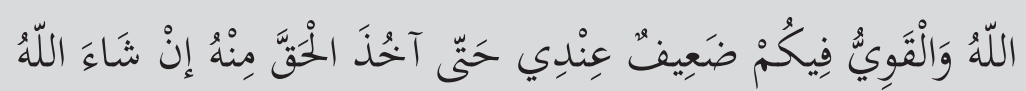

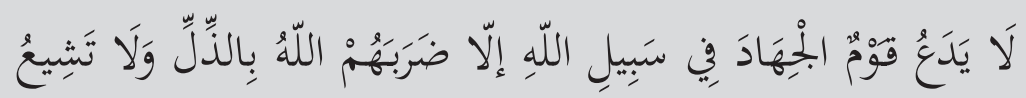

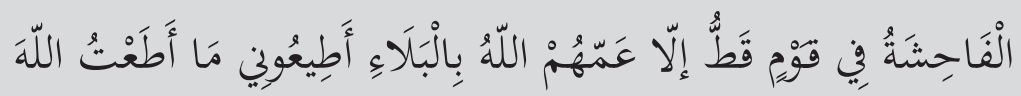

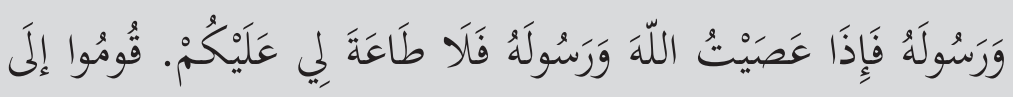

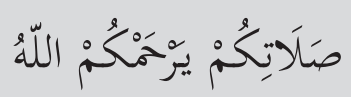

Amma ba'd. Wahai para manusia, sungguh aku telah dipilih menjadi pemimpin kalian, sedang aku bukanlah orang terbaik di antara kalian. Karenanya, jika aku berbuat kebajikan maka bantulah aku, dan jika berbuat keliru maka luruskanlah. Kejujuran adalah amanah dan kebohongan adalah penghianatan. Orang yang lemah di antara kalian ia di mataku adalah kuat sehingga aku mengembalikan apa yang menjadi haknya kepadanya. Sedang orang yang kuat di mataku adalah lemah sehingga aku mengambil darinya hak milik orang lain yang diambilnya, insya Allah. Tidaklah suatu kaum yang meninggalkan jihad di jalan Allah kecuali Allah timpakan kehinaan. Dan sama sekali tidak ada kekejian tersebar pada suatu kaum kecuali Allah timpakan bala kepada mereka. Taatlah kalian kepadaku selama aku taat kepada Allah dan Rasul-Nya. Karenanya, apabila aku tidak taat kepada Allah dan Rasul-Nya maka wajib bagi kalian taat kepadaku. (Sekarang) berdirilah kalian untuk melaksanakan salat, niscaya Allah akan merahmati kalian. [Ibn Hisyam, 1427H, h. 393] 
Kepemimpinan Abu Bakar sebagai khalifah tak berlangsung lama. Ibnu Hibban dalam Șaḥị̣ Ibni Hibban bi Tartibi Ibni Balban mencatat hanya selama dua tahun tiga bulan dua puluh hari. Selama masa kepemimpinannya, ada banyak persoalan yang muncul, banyak orang-orang yang menyatakan keluar dari Islam serta enggan untuk membayar zakat.

\section{Model Khilafah Umar bin Khatab}

Peralihan kepemimpinan dari Abu Bakar ke Umar terjadi melalui penunjukan oleh Abu Bakar. Peralihan ini menurut az-Zuhri terjadi pada Selasa 22 Jumadil Akhir yang menurutnya merupakan khilafah yang sangat baik dan berhasil menaklukkan banyak wilayah. Hal ini sebagaimana dikemukakan oleh Jalaludin as-Suyuti:

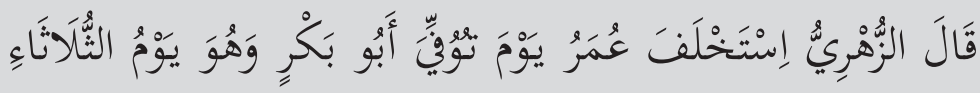

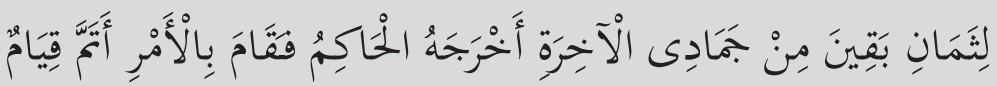

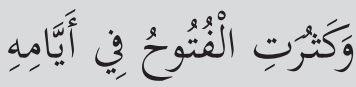

Az-Zuhri berkata, Umar ra. menjadi khalifah pada hari wafatnya Abu Bakar ra. yaitu hari Selasa delapan hari tersisa (tanggal 22) dari bulan Jumadil Akhir. Ini diriwayatkan oleh al-Hakim. Kemudian beliau mengemban amanat sebagai khalifah dengan sangat baik, dan pada masa kekuasaannya banyak wilayah yang berhasil ditaklukkan. [Jalaluddin al-Suyuthi, 1424 h. 108]

Di tangan Umar, Islam mengalami perluasan secara wilayah dan sistem kenegaraan mulai berkembang. Damaskus, Hims, Ba'labak, dan Bașrah adalah beberapa kota yang berhasil dikuasai pada masa kepemimpinan Umar. Di masa ini pula, umat Islam diseragamkan dalam melaksanakan salat tarawih, karena sebelumnya terpencar- 
pencar ke dalam beberapa imam. Khalifah Umar bin Khatab ra. juga dikenal sebagai orang yang pertama kali membuat institusi diwan atau catatan pendapatan dan pengeluaran publik dalam sejarah pemerintahan Islam. Dan menetapkan peristiwa hijrah Nabi Saw. dari Mekah ke Madinah sebagai awal kalender Islam.

Menurut Ibnu Hibban, kepemimpinan Umar berlangsung selama 10 tahun enam bulan lebih empat malam (Ibnu Hibban, 1414 M). Beliau wafat setelah ditikam oleh Abu Lu'luah dari kalangan Majusi Persia, budak Mugirah bin Syu'bah. Penikaman itu terjadi ketika beliau hendak menjalankan salat subuh.

\section{Model Khilafah Usman bin Affan}

Berbeda dengan dua model peralihan khilafah sebelumnya, peralihan kekuasaan dari Umar ke Usman menggunakan sistem formatur yang terdiri dari 6 orang yang telah ditentukan oleh Umar sebelum wafat. Keenam anggota formatur itu adalah Abdurrahman bin Auf, Sa'ad bin Abi Waqaș, Thalhah bin Ubaidillah, Zubair bin Awwam, Usman bin Affan, dan Ali bin Abu Thalib.

Dan keenam orang tersebut sepakat menunjuk Usman sebagai khalifah pengganti Umar bin Khatab. Namun ada peristiwa menarik yang dituturkan oleh Ibnu Katsir mengenai apa yang dilakukan oleh Abdurrahman bin Auf ra. sebelum menentukan pilihannya kepada Usman bin Affan ra.

Dalam benak Abdurrahman bin Auf ra. ada dua sahabat yang layak untuk menggantikan khalifah Umar bin Khatab, yaitu Usman bin Affan dan Ali bin Abu Thalib. Namun sebelum menentukan pilihan, ia melakukan blusukan ke bawah untuk mengetahui siapa di antara kedua orang tersebut yang paling dikehendaki rakyat.

Selama tiga hari tiga malam Abdurrahman bin Auf mendatangi para tokoh masyarakat dan menanyakan kepada mereka tentang siapa yang lebih dikehendaki untuk menjadi khalifah. Bahkan bukan hanya para tokoh masyarakat, tetapi juga sampai menanyakan kepada para 
perempuan, anak-anak, rombongan kafilah dan orang badui yang datang ke Madinah.

Dalam blusukannya, Abdurrahman bin Auf tidak menjumpai dua orang yang saling berselisih mengenai diajukannya Usman bin Affan ra., sebagai khalifah kecuali Ammar dan al-Miqdad di mana keduanya cenderung memilih Ali bin Abi Thalib sebagai khalifah pengganti khalifah Umar bin Khatab ra.

Jasa terbesar khalifah Usman bin Affan ra. adalah upayanya untuk mengumpulkan al-Quran menjadi satu mushaf yang kemudian dikenal dengan sebutan Musḥaf Usmāni. Beliau berkuasa selama kurang lebih sepuluh tahun. Dan wafat setelah sebelumnya dikepung oleh para pemberontak selama empat puluh hari, kemudian dimakamkan di pemakaman Baqi'.

Di antara empat khalifah pada masa awal Islam, khalifah Usman bin Affan ra., termasuk yang paling lama menjabat. Yaitu selama dua belas tahun kurang dua belas hari (Ibnu Hibban, 1414M).

\section{Model Khilafah Ali bin Abi Thalib}

Setelah wafatnya khalifah Usman bin Affan ra., para sahabat kemudian membaiat Ali bin Abi Thalib sebagai khalifah ke empat. Namun masa kekhalifahan Ali bin Abi Thalib ternyata tidak berjalan dengan mulus. Sebab ada perang saudara yang dikenal dengan perang Unta (jamal) dan perang Shiffin.

Perang Unta terjadi antara kubu Aisyah, Thalhah dan Zuber dengan kubu khalifah Ali bin Abi Thalib. Disebut perang Unta karena Aisyah ketika dalam pertempuran tersebut menunggang unta (Philip K. Hitti, 2013). Dan perang Shiffin antara kubu khalifah Ali bin Abu Thalib dengan kubu Muawiyah.

Pada masa kekhalifahan Ali bin Abu Thalib, beliau memindahkan ibu kota dari Madinah ke Kufah. Dan memberhentikan para pejabat yang diangkat khalifah Usman bin Affan. Langkah khalifah Ali bin 
Abi Thalib ternyata mendapat perlawanan yang sangat keras dari Muawiyah yang merupakan gubernur Suriah dan kerabat khalifah Usman bin Affan.

Kemudian Muawiyah menuntut balas atas kematian khalifah Usman bin Affan. Khalifah Ali bin Abi Thalib dihadapkan pada pilihan dilematis; menyerahkan para pembunuh khalifah Usman bin Affan atau menerima status sebagai pihak yang harus bertanggungjawab atas pembunuhan tersebut. Jika pilihannya adalah yang kedua, maka beliau harus mengundurkan diri dari jabatan khalifah.

Dalam perang Shiffin kubu khalifah Ali bin Abi Thalib banyak mengalami kerugian, dan dicurangi oleh kubu Muawiyah. Sebenarnya kubu Muawiyah hampir saja kalah, tetapi kemudian mereka mengajukan tahkim (arbitrase). Tahkim tersebut disepakati oleh kubu khalifah Ali bin Abi Thalib. Peperangan pun akhirnya berhenti.

Dalam tahkim yang diajukan dari kubu khalifah Ali bin Abi Thalib adalah Abu Musa al-Asy'ari, sahabat yang sangat saleh namun tidak begitu lihai dalam bermain politik. Sedang dari kubu Muawiyah adalah Amr bin al-Ash, yang masyhur sebagai politikus handal bangsa Arab.

Tawaran tahkim dari kubu Muawiyah yang diterima kubu khalifah Ali bin Abu Thalib ternyata sangat merugikan kubu sang khalifah. Di antaranya adalah turunnya dukungan dari kalangan yang pada mulanya sangat simpati kepada beliau. Kelompok ini kemudian melakukan pembelotan, dan di kemudian hari dikenal dengan sebutan Khawarij (orang-orang yang membelot), yang memiliki slogan la hukma illa lillah (tidak ada hukum kecuali hukum Allah).

Konflik internal umat Islam pada masa khalifah Ali bin Abi Thalib berujung kepada kematian beliau di tangan Abdullah bin Muljam, seorang Khawarij, ketika dalam perjalanan menuju masjid Kufah. Dan dalam riwayat Ibnu Hibban kekuasaan berlangsung selama lima tahun tiga bulan kurang empat belas hari. 


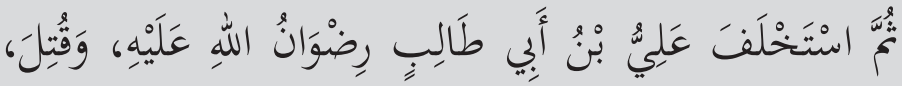

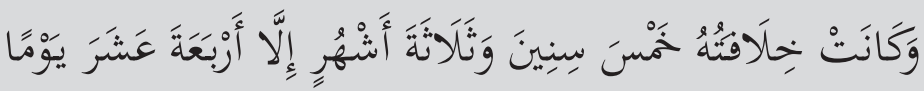

Kemudian Ali bin Abi Thalib menjadi khalifah lalu (wafat) karena dibunuh. Tampuk kekhalifahan ia pegang selama lima tahun tiga bulan kurang empat belas hari. [Ibnu Hibban, $1414 \mathrm{M}$ ]

\section{Lalu Bagaimana dengan Indonesia?}

Jika mencermati model-model khilafah di atas, maka sangat tampak bahwa tidak ada model baku perihal model khilafah seperti apa yang diperintahkan oleh Allah dan dijalankan oleh Nabi Muhammad. Terlebih, model kekhalifahan ini terjadi pada masa setelah Nabi Muhammad Saw. wafat. Karena itulah, mayoritas ulama menyerahkan kepada umat perihal model dari khilafah tersebut. Esensi dari khilafah ini adalah terjaminnya kelestarian ajaran Islam dan terwujudnya tatanan masyarakat yang baik.

Abu Manșur Abd al-Qahir al-Bagdadi dalam Ușul ad-Din mengatakan

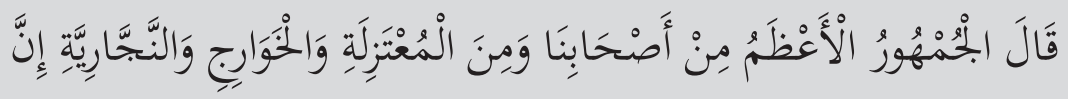

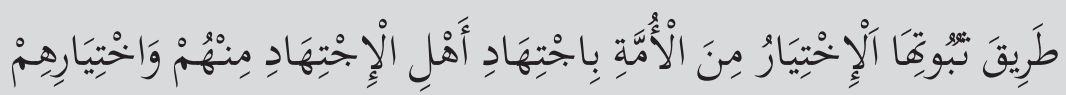

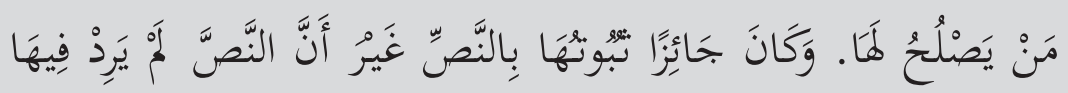

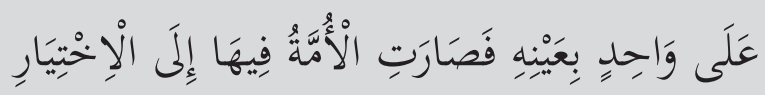

Mayoritas ulama dari sahabat-sahabat kami (ahl as-sunnah wa al-jamaah), mu'tazilah, khawarij, dan najjariyyah berpendapat bahwa sesungguhnya cara penetapan model kekhilafahan itu berdasarkan kehendak umat, hasil ijtihad para mujtahid dan pilihan mereka terhadap orang yang layak mengemban 
khilafah. Dan penetapan model kekhilafahan boleh saja menggunakan nash tetapi tak satu pun nash yang secara tegas menjelaskan model kekhilafahan. Karenanya, umatlah yang berhak menentukan model kekhilafahan.

Pendapat di atas sesuai dengan pernyataan Imam Adluddin al-Iji sebagaimana yang dikutip oleh Wahbah az-Zuhaili dalam al-Fiqh al-Islam wa Adillatuhu.

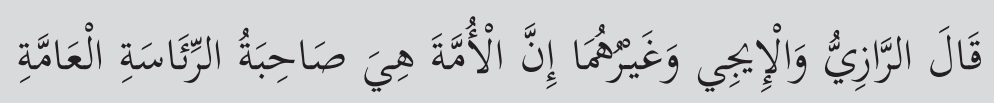

"Imam ar-Razi, al-lji, dan selainnya berpendapat bahwa umat adalah pemiliki kepemimpinan yang umum"

Atas hal inilah, Wahbah az-Zuhaili mengatakan:

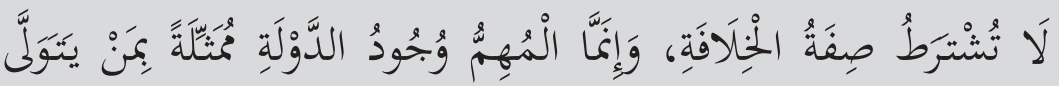

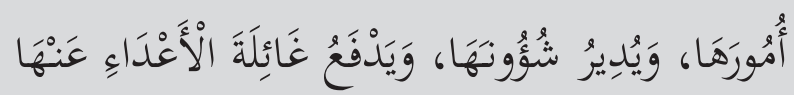

Tidak disyaratkan sifat (model) kekhilafahan (tertentu). Tetapi yang terpenting adalah keberadaan negara yang mencerminkan adanya orang yang menguasai dan mengatur urusan negara serta melindunginya dari serangan musuh.

Berdasarkan hal tersebut, apakah Indonesia perlu menjadi negara khilafah atau sebenarnya telah menjadi negara khilafah. Jika mengikuti dua kriteria yang disodorkan oleh Imam Mawardi, yakni kelestarian ajaran agama dan tata kelola kehidupan masyarakat yang baik, maka dapat dikatakan bahwa Indonesia adalah model baru khilafah itu sendiri.

Ada beberapa argumen atas hal ini. Pertama, Pancasila bukan ajaran sekuler melainkan berisi tentang ajaran-ajaran Islam. Sila pertama yang 
berarti ketuhanan yang Maha Esa, sudah berulangkali ditegaskan dalam al-Quran, seperti yang tertera dalam an-Nahl: 22, surah al-Baqarah: 163, surah al-Hasyr: 22-24, dan lain sebagainya. Begitu pula dengan sila kedua. Prinsip kemanusiaan, keadilan dan peradaban sangat banyak dan mudah ditemui baik dalam al-Quran, hadis, maupun perkataan para ulama, seperti surah at-Tin: 4, surah al-Hujuraat: 11, surah al-Maidah: 2 dan an-Nahl: 90.

Sila ketiga yang memuat soal persatuan juga ditegaskan dalam sejumlah ayat dalam al-Quran dan hadis Nabi. Beberapa contoh adalah surah alHujurat:13, surah al-Hujurat: 9, Ali Imran: 103. Sila keempat yang secara tersirat memerintahkan untuk bermusyawarah juga banyak diperintah oleh Allah dalam al-Quran seperti surah asy-Syura:38, surah al-Mujadilah: 9, Ali Imron: 159, Shaad: 20, dan lain sebagainya. Terakhir sila kelima yang berisi tentang keadilan sosial juga dapat dijumpai dalam sejumlah ayat dalam al-Quran, seperti an-Nisa: 58, an-Nahl: 90, al-Maidah: 08, an-Nisa: 135.

Kedua, Indonesia juga menjamin tatanan kehidupan masyarakat yang baik. Seperti kita tahu bahwa Indonesia terdiri dari beberapa suku, etnis dan agama. Kesemuanya itu setara di hadapan negara. Jaminan serupa kepada pemeluk agama lain juga dapat dijumpai dalam piagam Madinah dari pasal 25 sampai 35 :

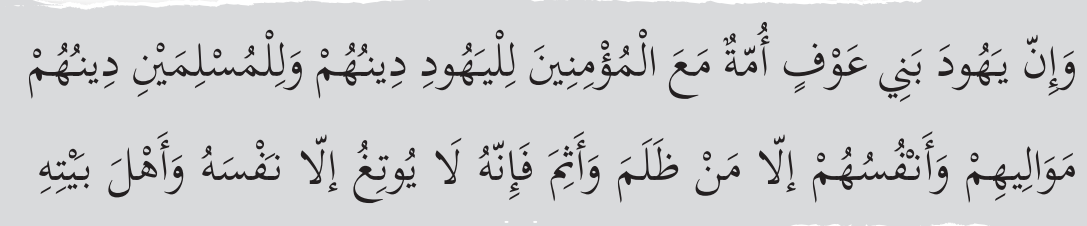

"Pasal 25; Yahudi Bani 'Auf adalah satu umat dengan kaum Mukminin, bagi kaum Yahudi, agama mereka dan bagi kaum muslimin agama mereka, baik sekutu-sekutu mereka dan diri-diri mereka kecuali orang yang lalim dan jahat. Sesungguhnya hal itu tidak akan merusak kecuali dirinya dan keluarganya". 


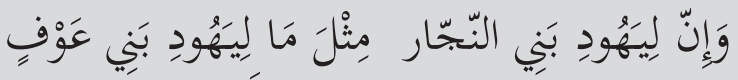

"(Pasal 26) Dan sesungguhnya bagi kaum Yahudi Bani Najjar mendapatkan perlakuan yang sama seperti kaum Yahudi Bani 'Auf"

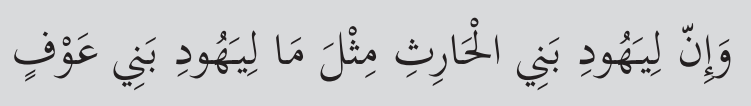

"(Pasal 27) Dan sesungguhnya bagi kaum Yahudi Bani Haris mendapatkan perlakuan yang sama seperti kaum Yahudi Bani 'Auf"

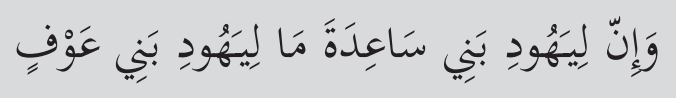

“(Pasal 28) Dan sesungguhnya bagi kaum Yahudi Bani Sa'idah mendapatkan perlakuan yang sama seperti kaum Yahudi Bani 'Auf"

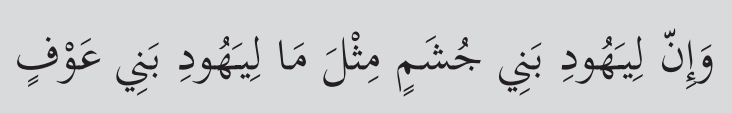

"(Pasal 29) Dan sesungguhnya bagi kaum Yahudi Bani Jusyam mendapatkan perlakukan yang sama seperti kaum Yahudi Bani 'Auf"

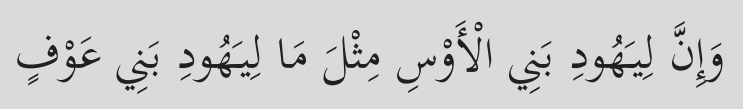


"(Pasal 30) Dan sesungguhnya bagi kaum Yahudi Bani Aus mendapatkan perlakukan yang sama seperti kaum Yahudi Bani 'Auf"

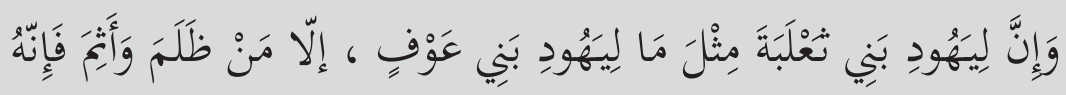

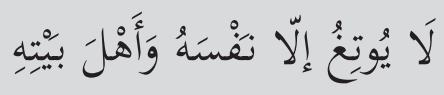

“(Pasal 31) Dan sesungguhnya kaum Yahudi Bani Śa'labah mendapatkan perlakuan yang sama seperti kaum Yahudi Banu 'Auf, kecuali orang yang Ialim dan jahat. Sesungguhnya hal itu akan tidak akan merusak kecuali dirinya dan keluarganya"

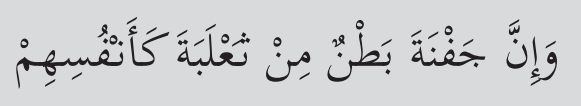

“(Pasal 32) Dan sesungguhnya suku Jafnah dari Bani Śa'labah mendapatkan perlakuan seperti mereka (Bani Ś'labah)”

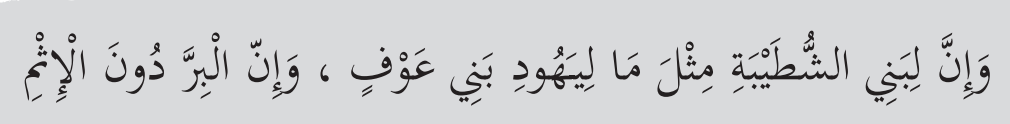

"(Pasal 33) Dan sesungguhnya bagi Bani Syuthaibah mendapatkan perlakuan yang sama seperti kaum Yahudi Bani 'Auf. Dan sesungguhnya kebaikan itu berbeda dengan kejahatan" 


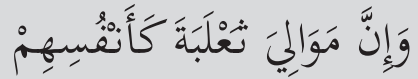

“(Pasal 34) Dan sesungguhnya sekutu-sekutu Bani Sa'labah mendapatkan perlakuan seperti mereka (Bani Ś'labah)"

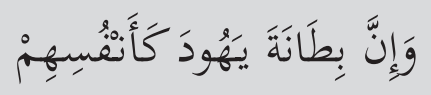

"(Pasal 35) Dan sesungguhnya kerabat kaum Yahudi (di luar kota Madinah) mendapatkan perlakuan seperti mereka (Yahudi)"

Alasan ketiga, secara praktik, Indonesia tidak memberikan pembatasan terhadap praktik keberislaman. Tidak ada larangan seseorang melaksanakan salat, mengeluarkan zakat, melaksanakan haji. Sebaliknya, negara justru mengatur, mengakomodasi ketentuan-ketentuan Islam dalam sejumlah peraturan dan kebijakan. Tersebutlah misalnya, UU pernikahan, berdirinya lembaga zakat, adanya badan urusan haji, bahkan untuk menghormati umat Islam yang melaksanakan idul fitri, negara juga memberlakukan hari libur. 


\section{Apakah Demokrasi Haram?}

Istilah demokrasi berasal dari bahasa Yunani dēmokratía "kekuasaan rakyat", yang dibentuk dari kata dêmos yang bermakna "rakyat" dan kratos yang berarti “kekuasaan", merujuk pada sistem politik yang muncul pada pertengahan abad ke-5 dan ke-4 SM di negara kota Yunani Kuno, khususnya Athena, menyusul revolusi rakyat pada tahun 508 SM.

Sistem ini lahir dalam konteks pelibatan rakyat secara langsung dalam membuat suatu keputusan. Sebagai sebuah konsep dan ideologi, demokrasi terus mengalami perkembangan konsep dan pemikiran. Begitu pula dengan definisinya yang tak memungkinkan diringkas hanya dalam satu kalimat. Demokrasi juga dapat dikategorikan sebagai bentuk pemerintahan, selain monarki dan aristokrasi.

Sebagai bentuk pemerintahan, demokrasi secara sederhana adalah bentuk pemerintahan di mana pemerintahan tersebut dipegang oleh rakyat dan dijalankan untuk kepentingan rakyat. Demokrasi juga dapat dianggap sebagai sistem politik yang berpijak pada prinsip bahwa kebijaksanaan umum ditentukan atas dasar mayoritas oleh wakil-wakil yang diawasi oleh rakyat dalam pemilihan berkala dengan berdasarkan pada prinsip kesamaan politik. Demokrasi juga dapat diposisikan sebagai sikap hidup yang berarti partisipasi dari setiap warga negara dalam membentuk nilainilai yang mengatur kehidupan.

Ulasan lebih detail tentang sejarah dan konsep demokrasi dapat dijumpai di sejumlah artikel lain. Tulisan ini hendak mengulas, bagaimana Islam dan muslim sebaiknya memandang demokrasi? Perlu diingat bahwa kata demokrasi tentu tidak ditemukan dalam sumber utama Islam; al-Quran dan hadis Nabi. Namun bukan berarti, secara konsep demokrasi tak dapat ditemukan rujukannya dalam Islam. Justru, prinsip-prinsip pokok demokrasi sesuai dengan ajaran Islam, sebagai berikut:

Pertama, konsep syura' (musyawarah). al-Quran mengajarkan bahwa pengambilan sebuah keputusan perlu ditempuh melalui musyawarah, sebagaimana yang termaktub dalam surah Asy-Syura': 38 


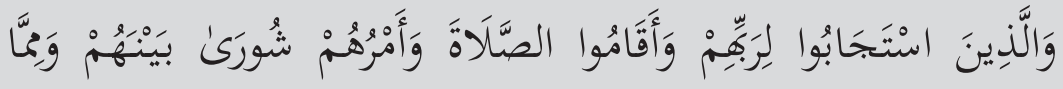

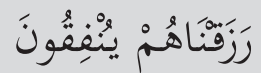

Artinya: Dan (bagi) orang-orang yang menerima (mematuhi) seruan Tuhannya dan mendirikan salat, sedang urusan mereka (diputuskan) dengan musyawarat antara mereka; dan mereka menafkahkan sebagian dari rezeki yang Kami berikan kepada mereka. [QS asy-Syura': 38]

Ajakan untuk bermusyawarah ini ada dalam surah Ali Imran: 159

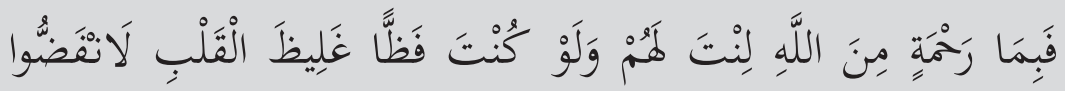

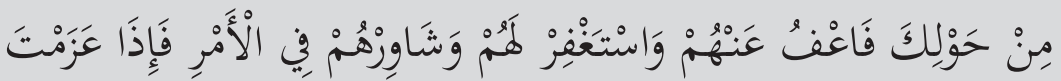

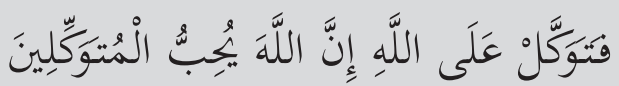

Artinya: Maka disebabkan rahmat dari Allah-lah kamu berlaku lemah lembut terhadap mereka. Sekiranya kamu bersikap keras lagi berhati kasar, tentulah mereka menjauhkan diri dari sekelilingmu. Karena itu maafkanlah mereka, mohonkanlah ampun bagi mereka, dan bermusyawarahlah dengan mereka dalam urusan itu. Kemudian apabila kamu telah membulatkan tekad, maka bertawakallah kepada Allah. Sesungguhnya Allah menyukai orang-orang yang bertawakal kepada-Nya. [QS Ali Imran: 159]

Dalam catatan sejarah, Nabi mencontohkan bagaimana bermusyawarah kepada umatnya, misalnya soal penentuan hari dan mengatur strategi untuk peperangan Badar, di mana tempat terbaik untuk menunggu musuh dalam perang Uhud. Bahkan, dalam perang Khandaq, keputusan 
untuk membuat parit-parit-yang saat itu tidak dikenal dalam strategi peperangan di jazirah Arab-lahir melalui musyawarah dengan sahabatsahabatnya. Dengan contoh ini, Nabi mengajarkan bahwa kita sebagai manusia tidak boleh merasa lebih tahu dan benar sehingga tidak memerlukan musyawarah dengan orang lain. Bahkan Nabi bersabda أنتم أعلم بأمور دنياكم (bahwa kalian lebih tahu dalam urusan duniamu).

Kedua, berdasarkan konstitusi dan hukum yang dihasilkan berdasarkan prinsip ijma' (konsensus). Sebagaimana yang telah disinggung pada bagian Pancasila, bahwa Pancasila dan UUD adalah kesepakatan bangsa Indonesia, termasuk umat Islam, yang harus dipatuhi. Di era Nabi Muhammad, ketentuan untuk mengatur kehidupan bermasyarakat secara majemuk dapat dijumpai melalui Piagam Madinah. Sementara, bagaimana untuk mengatur internal umat Islam maka pasti merujuk pada al-Quran, Rasulullah (hadis), dan kesepakatan ulama (ijma').

Dari sini dapat dipahami bahwa konstitusi dan hukum yang dilahirkan oleh negara tidak boleh bertentangan dengan aturan-aturan Allah. Alhasil, untuk mengatur urusan internal umat seperti soal ibadah, maka umat Islam tetap harus mengikuti aturan-aturan Allah. Sementara, dalam kehidupan berbangsa dan bernegara, umat Islam mengikuti konstitusi dan aturan hukum yang berlaku.

Ketiga, konstitusi dan hukum harus dioreintasikan dalam kerangka mencapai keadilan (al-'adalah). Aturan-aturan yang ada tidak boleh tebang pilih, tumpul ke atas dan tajam ke bawah. Perintah Allah untuk menegakkan keadilan ini tersebar di sejumlah ayat al-Quran, seperti anNahl: 90, as-Syura:15, al-Maidah:8, an-Nisa': 58. Dalam surah an-Nahl: 90, Allah berfirman;

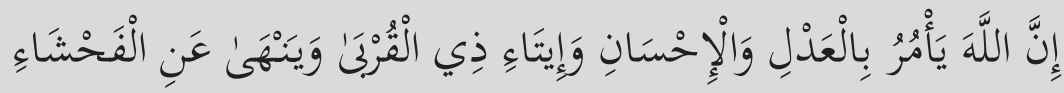

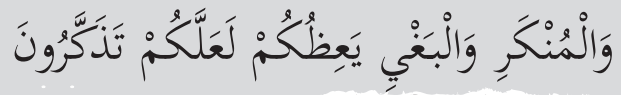


Artinya: Sesungguhnya Allah menyuruh (kamu) berlaku adil dan berbuat kebajikan, memberi kepada kaum kerabat, dan Allah melarang perbuatan keji, kemungkaran dan permusuhan. Dia memberi pengajaran kepadamu agar kamu dapat mengambil pelajaran. [QS an-Nahl: 90]

Bahkan, Allah tetap meminta jangan sampai kebencian terhadap seseorang ataupun kelompok membuat umat Islam tidak bisa bersikap adil, sebagaimana yang terekam dalam al-Quran surah al-Maidah: 08

Keempat, al-Mușawah atau kesejajaran, artinya tak seorangpun yang dapat merasa lebih tinggi dan berkuasa atas yang lain sehingga dapat memaksakan kehendaknya. Pemimpin yang berkuasa sekalipun tak berarti dapat berlaku sewenang-wenang, melainkan harus diorientasikan kepada kemashlahatan umat. Dalam kaidah fikih disebutkan (bahwa kebijakan pemimpin kepada rakyatnya harus sejalan dengan kemaslahatan atau kepentingan umum. Dalam konteks hukum, tak ada seorangpun yang kebal hukum, semuanya setara di hadapan hukum.

Kelima, kebebasan (al-hurriyah). Islam juga menjamin bahwa manusia memiliki kebebasan untuk mengekspresikan pendapatnya. Kebebasan di sini bukan berarti bebas sebebas-bebasnya tanpa aturan. Namun, kebebasan itu harus dilakukan secara bertanggungjawab, berakhlak dan tidak melanggar ketentuan yang berlaku. Bahkan, umat manusia juga punya kebebasan untuk menentukan dirinya apakah akan menjadi Mukmin ataukah kafir (Surah al-Kahfi: 29).

Kelima nilai-nilai tersebut menjadi landasan bahwa demokrasi di Indonesia harus diorientasikan kepada -sekurang-kurangnya-penegakan lima nilainilai tersebut, sehingga umat Islam tidak hanya menjadi muslim yang baik, tetapi juga menjadi warga negara yang baik pula. Walhasil, jika demokrasi kita bersandar kepada kelima prinsip tersebut, maka demokrasi bukan saja tidak haram, melainkan juga wujud dari implementasi nilai-nilai Islam itu sendiri. 


\section{Keharusan Mencintai Negara}

Sebagai bangsa Indonesia yang beragama Islam, tentu seluruh umat Islam diperintahkan untuk menaati pemimpinnya serta mencintai tanah airnya (negaranya). Secara terminologi, istilah nasionalisme tidak dikenal dalam Islam klasik karena paham ini baru mengemuka pada akhir abad 18. Islam klasik biasanya membagi wilayah ke dalam dua bagian: wilayah damai (dar al-Islam) dan wilayah perang (dar al-Harb).

Kendatipun demikian, bukan berarti konsep nasionalisme tidak dapat ditemukan rujukannya dalam Islam. Islam mengenal konsep ummah yang oleh al-Asfahani dimaknai sebagai perkumpulan manusia yang dipersatukan oleh urusan tertentu baik faktor agama, waktu yang sama ataupun tempat yang sama. Bagi Ibn Khaldun (Fattah, 2004), terma ummah ini serupa dengan kata wathan yang bermakna hubungan tertentu antar kelompok masyarakat yang mendiami wilayah teritorial tertentu.

Secara konseptual, al-Quran pun merekam bagaimana Nabi Ibrahim yang karena kecintaannya kepada negerinya berdoa sebagaimana yang terekam dalam surah al-Baqarah ayat 126 dan surah Ibrahim ayat 35 sebagai berikut:

\section{وَ إذذْ قَالَ إِبرُاهِيْنُ رَبِّ اجْعَلْ هَذَا بَلًََا آمِنًا}

Dan (ingatlah), ketika Ibrahim berdoa: "Ya Tuhanku, jadikanlah negeri ini, negeri yang aman sentosa....."

Salah satu cara mewujudkan negeri yang aman sentosa sebagaimana yang ada dalam doa Nabi Ibrahim, maka;

1) Seluruh elemen bangsa harus menjaga persatuan dan kesatuan, sebagaimana yang diperintahkan Allah dalam surah Ali Imran ayat 103: 


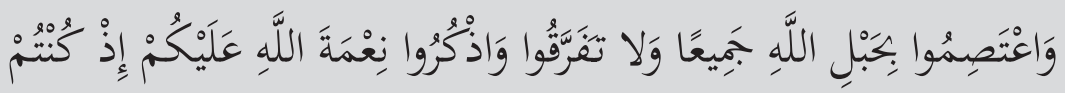

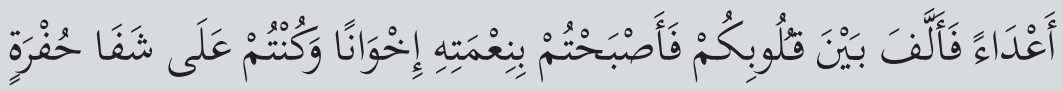

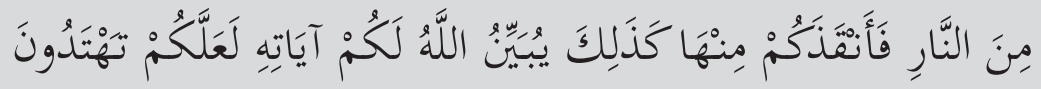

Dan berpeganglah kamu semuanya kepada tali (agama) Allah, dan janganlah kamu bercerai berai, dan ingatlah akan nikmat Allah kepadamu ketika kamu dahulu (masa Jahiliah) bermusuh musuhan, maka Allah mempersatukan hatimu, Ialu menjadilah kamu karena nikmat Allah orang-orang yang bersaudara; dan kamu telah berada di tepi jurang neraka, lalu Allah menyelamatkan kamu daripadanya. Demikianlah Allah menerangkan ayat-ayat-Nya kepadamu, agar kamu mendapat petunjuk. . [QS Ali Imran: 103]

2) Sebagai konsekuensi, bangsa Indonesia berada dalam satu ummah di mana menurut Ali Syariati (1995) bahwa ummah itu mengandaikan adanya pemimpin, maka seluruh ummah Indonesia diperintahkan untuk taat kepada pemimpin sebagaimana yang diperintahkan oleh Allah

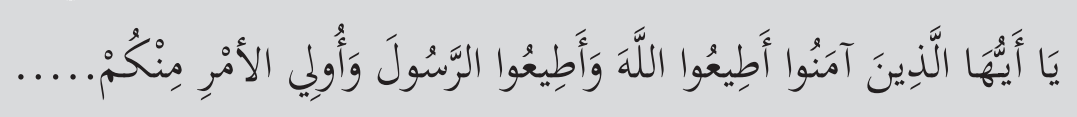

"Hai orang-orang yang beriman, taatilah Allah dan taatilah Rasul (Nya), dan ulil amri di antara kamu....." [QS an-Nisa': 58]

Kehidupan ummah Madinah ketika dipimpin oleh Nabi Muhammad juga menunjukkan bagaimana setiap komunitas di Madinah tunduk kepada Nabi Muhammad. Ketundukan orang-orang selain beragama Islam di Madinah bukan dalam pengertian ketundukan terhadap agama yang dibawa oleh Nabi Muhammad melainkan ketundukan kepada Nabi Muhammad sebagai pemimpin tertinggi negara Madinah. 
3) Kehidupan damai dan aman juga dapat diwujudkan melalui kesepakatan atau peraturan bersama antar beragam komunitas yang harus ditaati bersama sebagaimana yang dapat dilihat dalam Piagam Madinah. Dalam pasal 25 Piagam Madinah, misalnya berbunyi:

Sesungguhnya Yahudi Bani Auf satu umat bersama orang-orang Mukmin, bagi kaum Yahudi agama mereka dan bagi orang muslim agama mereka, termasuk sekutu-sekutu dan diri mereka, kecuali orang-orang yang berlaku zalim dan berbuat dosa atau berkhianat. Karena sesungguhnya yang demikian hanya akan melecehkan diri dan keluarga.

Dalam konteks kehidupan bernegara di Indonesia, peraturan bersama yang telah disepakati bersama oleh para pendiri bangsa itu adalah Pancasila dan UUD 1945 beserta Undang-Undang dan peraturan lainnya. Dengan adanya peraturan bersama, maka satu kelompok tidak boleh mengusir kelompok lain. Nah, untuk menghasilkan kesepakatan atau peraturan bersama itu maka masing-masing kelompok atau perwakilannya perlu duduk bersama untuk bermusyawarah. al-Quran benar-benar memberi tuntunan yang sangat baik soal bagaimana berinteraksi dengan kelompok lain yang harus dilakukan secara lemah lembut, tidak keras kepala dan memberikan maaf kepada mereka yang bersalah serta mengedepankan musyawarah, sebagaimana yang terangkum dalam Ali Imran 159

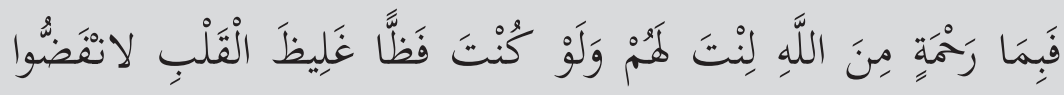

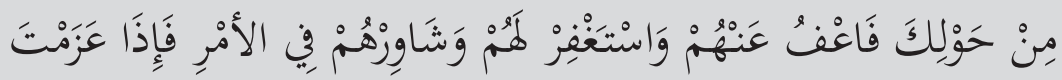

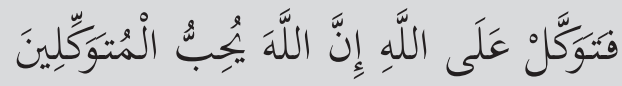

Maka disebabkan rahmat dari Allah-lah kamu berlaku lemah-lembut terhadap mereka. Sekiranya kamu bersikap keras lagi berhati kasar, tentulah mereka menjauhkan diri dari sekelilingmu. Karena itu maafkanlah mereka, 
mohonkanlah ampun bagi mereka, dan bermusyawarahlah dengan mereka dalam urusan itu. Kemudian apabila kamu telah membulatkan tekad, maka bertawakallah kepada Allah. Sesungguhnya Allah menyukai orang-orang yang bertawakal kepada-Nya. [QS. Ali Imran 159]

Mengambil keputusan secara bersama-sama dalam suatu ummah belakangan ini disebut sebagai demokrasi. Mengapa demikian? Dalam demokrasi, kekuasaan tidak dipegang dan ditentukan oleh satu orang ataupun satu kelompok, melainkan diatur bersama dan untuk kepentingan bersama. Sebagai sebuah sistem, demokrasi tentu memiliki kekurangan dan hambatan-hambatan dalam implementasinya. Tetapi, atas kesepakatan bersama, setiap ummah dapat melakukan revisi terhadap sistem demokrasi, sebagaimana yang pernah terjadi di Indonesia mulai dari demokrasi parlementer, demokrasi terpimpin, demokrasi Pancasila, bahkan di era reformasi ini setiap warga negara memiliki hak suara yang sama untuk menentukan pemimpinnya dalam pesta demokrasi yang bernama pemilihan umum. 


\section{Hormat Bendera, Haramkah?}

Pendapat tentang haramnya hormat bendera berlaku di kalangan salafi dan Hizbut Tahrir. Sedangkan di kalangan umat Islam, hormat bendera (tahiyyatul 'alam al-wațoni) tidak dipersoalkan. Mereka yang mengharamkan hormat kepada bendera menganggap bahwa sikap hormat kepada bendera merupakan perbuatan syirik. Namun mereka sendiri tidak dapat menunjukkan dalil naqli maupun aqli terkait dengan pengharaman tersebut.

Belakangan ini hampir di setiap hari ulang tahun Republik Indonesia marak tulisan di media sosial serta pemberitaan bahkan ceramah-ceramah di media sosial mengenai pelarangan hormat bendera.

Pelarangan hormat bendera sebagaimana yang diutarakan oleh Muhammad Shidiq al-Jawi ketua DPP Hizbut Tahrir Indonesia (HTI) merupakan perbuatan haram. Hormat bendera itu bid'ah dan khurafat, bahkan sama dengan syirik atau menyekutukan Allah, mengikuti tradisi kaum kafir Yahudi dan Nasrani.

Golongan yang melarang hormat bendera di Indonesia didominasi oleh HTI dan Salafi Jihadi, argumentasi mereka lazim merujuk pada hadis riwayat Tirmiži.

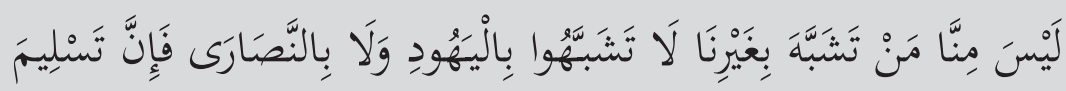

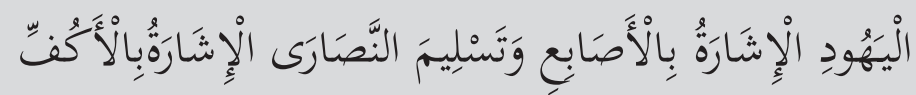

Bukanlah bagian dari kaum muslimin orang-orang yang menyerupai orangorang kafir. Janganlah kalian menyerupai orang-orang Yahudi ataupun Nasrani. Sesungguhnya penghormatan ala Yahudi adalah isyarat dengan jari jemari sedangkan penghormatan ala Nasrani adalah isyarat dengan telapak tangan. [HR Tirmiẓi] 
Pemahaman akan hadis yang tidak tepat, justru membawa kekeliruan yang sangat fatal, hingga akhirnya menolak kecintaan terhadap tanah air sebagai perwujudan dari nasionalisme.

Perlu dipahami, para ulama berbeda pendapat mengenai kesahihan atau validitas hadis tersebut. Para ulama bersepakat bahwa hadis-hadis yang berkenaan dengan larangan penyerupaan muslim dan non-muslim dari segi periwayatan atau sanad tidak sampai kepada derajat atau tingkatan hadis sahih bahkan dihukumi dha'if (lemah).

Selanjutnya, apa yang dimaksud dengan penyerupaan atau bahasa yang sering digunakan adalah tasyabuh. Wahyu yang turun tidak terlepas dari konteks yang berlaku saat itu, sebagaimana al-Quran yang diturunkan untuk memberikan jawaban atas problematika umat muslim saat itu. Dengan kata lain, bahwa ada latar belakang, serta konteks budaya terkait. Begitu pula dengan hadis.

Latar belakang atau asbāb al-wurūd turunnya hadis larangan penyerupaan dengan non-muslim adalah sebagai berikut; pada suatu hari ada seorang non-muslim masuk Islam, kemudian berkumpul bersama Nabi dan para sahabat membicarakan strategi dakwah secara internal. Pada sore harinya, seseorang yang tadi mengaku masuk Islam kembali kafir, keluar dari Islam. Maka turunlah larangan penyerupaan dengan non-muslim. Dapat dipahami konteks dari pada larangan adalah mengenai politik identitas yang membedakan antara muslim dan non-muslim kala itu. Unsur larangan tasyabuh yang dimaksud adalah berkaitan dengan keimanan, yakni akidah dan ibadah yang hendak menjelaskan bahwa identitas keimanan kita berbeda dengan mereka.

Dalam beberapa hal, khususnya persoalan muamalah dan tidak berkaitan dengan akidah, justru Rasulullah Saw. tidak sekaku yang kita bayangkan. Terkadang beliau juga mengikuti penampilan ahl al-kitab dan model sisiran rambut mereka. Hal ini sebagaimana yang disaksikan langsung oleh Ibnu 'Abbas. 
Dari penjelasan di atas, dapat dipahami bahwa larangan penghormatan kepada bendera yang dikatakan haram dengan dasar argumentasi hadis di atas sangatlah tidak tepat. Penghormatan kepada bendera tidak dihukum haram dan tidak disamakan dengan perbuatan syirik.

Para ulama Saudi Arabia pernah membahas persoalan mengenai hormat bendera nasional, sebagaimana dirilis di dalam fatwa komisi tetap bidang fatwa ulama Saudi Arabia No. 118533. Di dalam fatwa nomor 103506 terdapat penjelasan bahwa berdiri di hadapan bendera bukan termasuk perbuatan syirik. Dalam kaitan ini, Komisi Fatwa Kerajaan Saudi Arabia tidak memberikan pandangan yang cukup jelas terkait hormat bendera. Dapat disimpulkan untuk sementara, bahwa para ulama Saudi Arabia menganggap praktik menghormat kepada bendera merupakan perbuatan makruh.

Pendapat lain mengenai penghormatan kepada bendera dijelasakan oleh Kementerian Urusan Agama dan Wakaf Republik Aljazair. Secara umum, Kementerian Urusan Agama menjelaskan bahwa menghormat bendera bukanlah perbuatan yang haram karena para sahabat banyak yang gugur pada Perang Yarmuk karena mempertahankan bendera. Pemerintah Aljazair juga tidak sependapat dengan pandangan yang menganggap menghormat bendera merupakan perbuatan syirik.

Argumen ini disasarkan pada sebuah hadis yang diriwayatkan dalam Șāḥih Bukhari, sebagaimana yang diceritakan oleh Anas bin Malik ra., bahwa Rasulullah Saw. menggunakan panji-panji, yakni serupa bendera dalam peperangan.

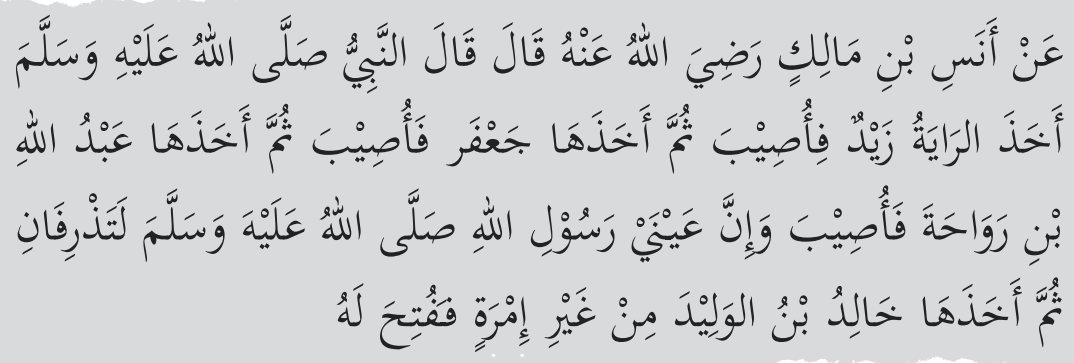


Dari Anas ra. ia berkata bahwa Rasulullah Saw. menceritakan bagian dari perang Mu'tah, panji perang dipegang oleh Zaid, lalu ia gugur. Panji perang kemudian diambil alih oleh Ja'far bin abi Thalib, ia pun kemudian gugur. Panji diraih oleh Abdullah bin Rawahah, ia pun gugur [sampai di sini kedua mata Rasulullah Saw. berlinang air mata, kata Anas]. Panji perang Ialu diambil Khalid bin Walid dengan inisiatifnya. ia maju menghantam pasukan musuh hingga mereka takluk di tangannya. [HR Bukhari]

Dalam peperangan, panji-panji atau bendera dipakai oleh Rasulullah guna menyalakan semangat juang para sahabat sebagaimana yang ditulisan oleh Ibnu Hajar al-Asqalani dalam Fath al-Bari.

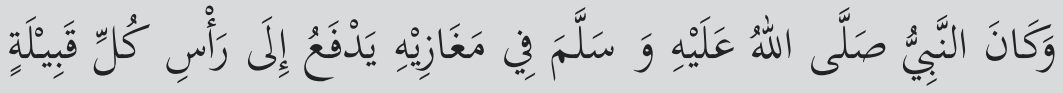

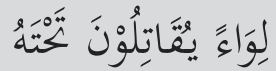

Rasulullah SAW dalam sejumlah peperangannya memberikan panji-panji kepada setiap pemimpin kabilah. Di bawah panji itu mereka berperang membela keadilan dan kedaulatan.

Pendapat di atas sejalan dengan cara pandang mayoritas ulama di Indonesia, bahwa penghormatan kepada bendera bukan penyembahan kepada benda mati, melainkan ungkapan cinta kepada tanah air dan penghargaan pada mereka yang sudah berjuang demi negeri ini.

Praktik hormat bendera itu bukanlah praktik ibadah. Akan tetapi, merupakan bentuk penghargaan atas semua usaha yang dilakukan untuk mempertahankan dan memperjuangkan eksistensi negara yang disimbolkan melalui bendera. Sejatinya bendera tesebut dihormati karena rasa cinta dan mengingat semangat jasa pahlawan terdahulu. 
Tidak ada dalil dalam al-Quran maupun hadis yang mengharamkan perihal tersebut. Rasulullah Saw. sendiri mempraktikkan bentuk kecintaannya kepada kota Mekah sebagai kota kelahirannya sebagaimana yang diriwayatkan oleh Ibnu Abas ra. dalam Șaḥiḥ ibnu Hibban:

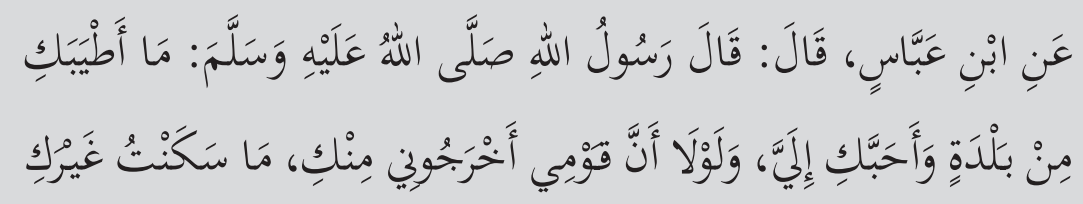

Dari Ibnu Abbas ra. ia berkata, Rasulullah Saw. Bersabda; alangkah baiknya engkau sebagai sebuah negeri, dan engkau merupakan negeri yang paling aku cintai. Seandainya kaumku tidak mengusirku dari engkau, niscaya aku tidak tinggal di negeri selainmu.

Dari berbagai keterangan di atas, dapat disimpulkan bahwa penghormatan kepada bendera bukan termasuk perbuatan syirik, dan tidak ada satu nash pun yang menjelaskan keharaman mengenai penghormatan kepada bendera. KH. Wahab Chasbullah, membuat seruan hubbul al-watan min al-imani, mencintai Tanah Air merupakan bagian dari Iman. Sejalan dengan hal tersebut, penghormatan kepada bendera lahir dari bentuk kecintaan seseorang terhadap Tanah Airnya.

Bendera merah putih sebagai simbol kenegaraan yang sudah sepatutnya dihargai oleh seluruh warga negara Indonesia. Penghormatan kepada bendera sebagai bentuk dari kecintaan kepada tanah air serta penghormatan akan jasa para pejuang terdahulu dalam membela kemerdekaan bangsa dan Negara Indonesia perlu dilestarikan serta ditumbuhkan dalam jiwa-jiwa warga negara Indonesia sebagai bentuk Nasionalisme.

Terakhir, yang perlu untuk dicatat, bahwa tidak ada satu pun nash yang menyatakan keharaman menghormati bendera. 



\section{BABENAM}

\section{ADAKAH ISLAM RADIKAL?}

slam adalah agama yang diturunkan Allah untuk menebar rahmat (cinta kasih) bagi alam semesta. Terdapat kurang lebih 90 ayat dalam al-Quran dengan derivasi berbeda-beda yang menjelaskan bahwa agama yang dibawa oleh Nabi Muhammad Saw. adalah agama kasih sayang sebagaimana firman Allah Swt. yang terdapat pada surah al-Anbiya ayat 107:

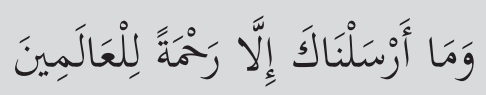

Dan tidaklah Kami mengutus kamu, melainkan untuk (menjadi) rahmat bagi semesta alam. [QS al-Anbiya: 107]

Islam dengan misi agar rahmatan lil alamin memberikan pesan bahwa Islam adalah agama yang mengajarkan kedamaian, keselamatan dan mengajarkan cinta kasih terhadap sesama manusia. 
Hal ini diperkuat dengan esensi dari diutusnya Rasulullah Saw. ke muka bumi ini sebagaimana dijelaskan dalam sebuah hadis masyhur yang diriwayatkan oleh Abu Hurairah ra. dalam Șaḥị̣ Bukhari dan Șaḥiḥ Muslim.

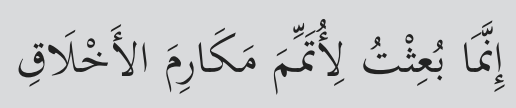

Aku diutus untuk menyempurnakan akhlak manusia. [HR Bukhari Muslim]

Nabi sendiri dalam seluruh kehidupannya mencerminkan perilaku penuh kasih sayang. Sebagaimana Siti Aisyah ra. berkata bahwa keseluruhan pribadi atau akhlak Rasulullah Saw. adalah cerminan dari al-Quran. Oleh karenanya, Rasulullah Saw. dengan tegas menolak kekerasan dan diskriminasi yang tidak sesuai dengan ajaran Islam.

Bahkan sikap penuh cinta kasih yang dipraktikkan oleh Rasulullah Saw. tidak hanya kepada sesama muslim, melainkan juga kepada non-muslim. Sebagaimana yang tersirat dalam al-Quran surah al-Mujadilah ayat 22;

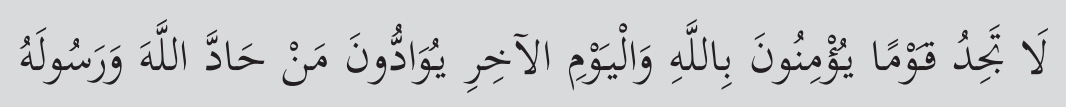

Kamu tidak akan mendapati sesuatu kaum yang beriman kepada Allah dan hari akhirat, saling berkasih sayang dengan orang-orang yang menentang Allah dan rasul-Nya. [QS al-Mujadilah: 22]

Ibnu Jarir at-Thobari dalam tafsirnya mengatakan bahwa ayat tersebut merupakan perintah untuk berbuat baik dan berlaku adil kepada siapapun baik sesama muslim maupun non-muslim. Inilah perilaku yang dicontohkan Rasulullah Saw.

Syaikh Mustofa al-'Adawi menjelaskan dalam kitab Tafsir Juz Qod Sami'a, "berbuat baik dan berlaku adil tidaklah melazimkan rasa cinta dan kasih 
sayang pada orang kafir. Seperti contohnya adalah seorang anak tetap berbakti dan berbuat baik pada orang tuanya yang kafir, namun ia tetap membenci agama yang orang tuanya anut. Dasar ini yang kemudian mengajarkan umat Islam untuk menebarkan kasih sayang serta berlaku adil kepada sesama manusia terlepas dari apapun itu agamanya. Perbedaan agama bukan berarti menghalangi sesama manusia untuk berbuat baik.

Lantas bagaimana dengan kelompok-kelompok yang mengaku dirinya menegakkan syariat Islam, hingga membunuh saudaranya sesama muslim, menghalalkan bom bunuh diri, serta memerangi pemerintahan yang sah. Kelompok-kelompok tersebut dikatakan sebagai kelompok Islam Radikal. Pertanyaan selanjutnya apakah ada kelompok Islam radikal dalam sejarah Islam?

Sejenak kita melihat sejarah, Rasulullah Saw. pernah memprediksikan dalam sebuah hadis dalam Șaḥị̣ Bukhari dan Muslim;

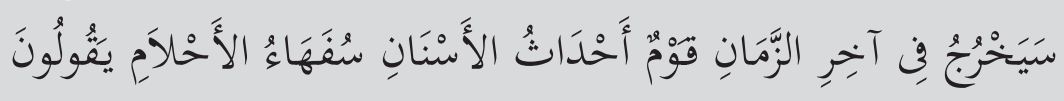

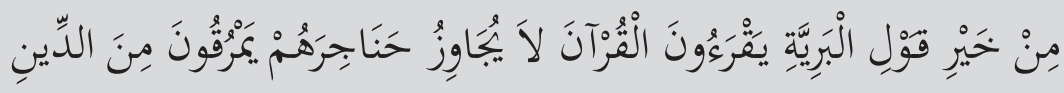

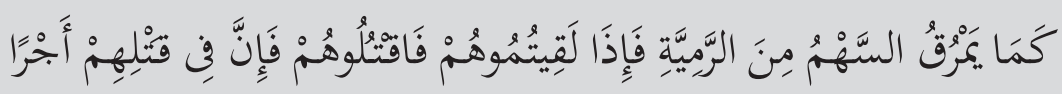

$$
\begin{aligned}
& \text { لِمَنْ فتَكَلَهُمْ عِنْدَ اللَّهِ يَوْمَ الْقِيَامَةِة }
\end{aligned}
$$

Akan muncul di akhir masa ini nanti sekelompok orang yang umurnya masih muda-muda dan lemah akalnya. Apa yang mereka ucapkan adalah perkataan manusia yang terbaik. Mereka suka membaca al-Quran akan tetapi bacaan mereka tidak sampai melewati pangkal tenggorokan mereka. Mereka melesat dari agama seperti halnya anak panah yang melesat dari sasaran bidiknya. Apabila kalian menjumpai mereka maka bunuhlah mereka. Karena sesungguhnya dengan terbunuhnya mereka maka orang yang membunuhnya itu akan mendapat pahala di sisi Allah pada hari kiamat kelak. [HR Bukhari Muslim] 
Inilah kelompok yang diprediksikan oleh Rasulullah Saw., yang membenarkan segala perbuatannya atas nama agama. Mereka merasa dirinya paling benar, ibadahnya paling rajin, bacaan al-Qurannya paling bagus, dan kalau bertemu mereka kita akan merasa kalah alim atau bahkan kurang Islami. Mereka tak segan menumpahkan darah sesama muslim karena pandangan ekstrem mereka.

Dalam sejarah Islam kelompok-kelompok ini pernah eksis yang disebut dengan kelompok Khawarij dengan salah satu karakter identik mereka adalah mudah mengafirkan orang lain, implikasi dari paham takfiri ini menghalalkan darah sesama muslim. Sejarah umat Islam mencatat bahwa terbunuhnya Sayidina Ali sebagai khalifah ke empat dengan dalih bahwa Sayidina Ali tidak menegakkan hukum Allah, maka harus dibunuh. Orang yang membunuh Ali bin Abi Thalib adalah Ibnu Muljam, seorang yang hafal al-Quran dan taat beribadah. Lewat pemahaman teks yang sempit, ia mencederai ajaran Islam yang sejatinya menebarkan kedamaian dan cinta kasih.

Cerita di atas, memberikan gambaran kepada kita bahwa untuk memahami ajaran Islam, tidak semata-mata cukup dengan membaca al-Quran dan mengambil satu atau dua potongan ayat dalam al-Quran melainkan harus melihat sejarah, tafsir, serta ilmu-ilmu lain yang mendukung seperti hadis, bahasa Arab dan piranti keilmuan lainnya. Sehingga tidak terjebak kepada pemahaman tekstualis.

Ekspresi keberagamaan macam inilah yang diadopsi oleh kelompok Islam Radikal, yang hanya memandang teks yang tertulis. Tanpa melihat tafsir serta kronologi turunnya ayat hingga pada tataran tertentu mengarah pada perbuatan atau tindakan ekstrimis, yakni membuat pembenaran terhadap apa yang dilakukan atas nama agama.

Sebagaimana yang telah diutarakan di atas, bahwa kelompok Islam radikal telah ada sebelumnya dalam sejarah Islam, dan telah diprediksikan oleh Rasulullah Saw. Maka karakteristik yang paling melekat dengan mereka adalah memahami teks-teks keagamaan secara tekstual, pemahaman 
tekstualis ini yang berimplikasi pada kecenderungan mudah untuk mengafirkan satu sama lain.

Dalam konteks modern kehidupan saat ini, mereka identik membangun hubungan atau jaringan dengan sesama kelompoknya dan menutup diri dengan orang lain, pengajian-pengajian mereka lakukan secara tertutup, dan hanya perkataan serta bacaan-bacaan guru dan kelompok merekalah yang dikonsumsi. Serta mudah untuk menyalahkan dan membid'ahkan.

Tentunya, agar kita terhindar dari pemahaman agama yang fundamental, tekstualis serta mudah mengafirkan dan menghalalkan darah sesama muslim, kita harus kembali memahami ajaran Islam yang rahmatan lil alamin, untuk memahami al-Quran kita perlu keilmuan-keilmuan lainnya. Keterbatasan kita untuk mengakses ajaran Islam sebagaimana yang diajarkan oleh Rasulullah Saw., kita harus kembali kepada para ulama, yakni ulama yang benar-benar memiliki kapasitas keilmuan dan kesolehan baik secara spiritual maupun secara sosial.

Yasir Alimin, dalam sebuah bukunya mengatakan bahwa salah satu penyebab munculnya gerakan Islam radikal, khususnya di Indonesia yang menjangkit generasi muda, adalah putusnya mata rantai atau hubungan antara Ulama dengan generasi muda saat ini.

Generasi millenial menganggap ulama adalah mereka yang tampil di media sosial, yang dapat dengan mudah mengajarkan Islam secara praktis, tanpa kita tahu bagaimana kapasitas keilmuannya. Hingga akhirnya kita terjebak kepada pemahaman yang sempit.

Pernyataan ini tentu saja seharusnya menginspirasi setiap muslim untuk melakukan langkah-langkah kemanusiaan yang tegas dalam menegakkan keadilan yang menjadi esensi ajaran Islam. Yakni mewujudkan suatu tatanan kehidupan manusia yang didasarkan pada pengakuan atas kesederajatan manusia di hadapan hukum (al-musâwah amâma al-hukm), penghormatan atas martabat (hifdh al-irdl), persaudaraan (al-ukhuwwah), penegakan keadilan (iqâmat al-'adl), pengakuan atas pikiran dan kehendak 
orang lain, dialog secara santun, serta kerjasama saling mendukung untuk mewujudkan kemaslahatan bersama. Ini adalah pilar-pilar kehidupan yang seharusnya ditegakkan oleh setiap umat Islam.

Dari paparan di atas tampak bahwa sebenarnya tidak ada Islam radikal, yang ada adalah orang-orang yang sejak semula bersikap dan bertindak radikal, dan yang kebetulan ia beragama Islam. Dan perlu diingat, bahwa ekspresi kebe-Islam-an seseorang itu cukup beragam sesuai dengan konteksnya. Praktik Islam yang ada di Indonesia tentu tidak sama persis dengan praktik Islam yang ada di Timur Tengah. Tentunya, terhadap ajaranajaran pokok Islam, semua umat di mana pun berada pasti sama, misalnya sama-sama melaksanakan salat, menunaikan zakat dan haji. Sementara, praktik-praktik cabang dalam Islam bisa sangat variatif. Misalnya, di Indonesia ada tradisi Halal bi Halal yang di negara mana pun tidak akan dijumpai. Tradisi-tradisi tersebut sejauh tidak bertentangan dengan esensi Islam tentu diperbolehkan.

Lalu, bagaimana caranya agar generasi millenial ini terhindar dari paham dan gerakan radikal? Tidak ada cara generik yang berlaku untuk semua elemen agar terhindar dari radikalisme, karena penyebab radikalisme cukup variatif. Namun demikian, secara umum sekurang-kurangnya ada empat langkah yang perlu dilakukan agar tidak terjebak ke dalam paham dan gerakan radikalisme.

Pertama, carilah guru yang tepat. Sebagai generasi milenial, temukan guru yang tepat yang memiliki kompetensi keislaman yang cukup mendalam. Cara paling gambang adalah cek latar belakang pendidikannya, berasal dari pesantren manakah, berasal dari perguruan tinggi Islam atau bukan, dan seterusnya.

Kedua, selalu questioning. Setiap informasi yang masuk ke telinga kita hendaknya selalu dipertanyakan kebenarannya. Sekalipun ia menyodorkan dalil yang tampak meyakinkan, jangan ragu untuk selalu mempertanyakan. Jika sekiranya tidak cukup memiliki bekal untuk bertanya secara kritis, ajukan kepada guru yang lain. Second opinion tentang suatu hal seringkali 
dapat membantu kita bukan saja mencegah dari radikalisme juga membuat kita dapat memahami Islam secara lebih mendalam.

Ketiga, batasi pergaulan baik secara offline maupun online. Perlu diketahui bahwa radikalisme terus dikampanyekan baik secara offline maupun online. Paham ini dapat saja menyita perhatian generasi muda untuk terlibat di dalamnya. Karena itu, batasilah pergaulan jika sekiranya anda masih belum percaya tentang ideologi dirinya, keyakinannya. Jika sudah memiliki keyakinan yang cukup, Anda dapat berselancar secara bebas, bahkan melakukan penelitian tentang radikalisme.

Keempat, terlibat dalam gerakan-gerakan yang menyuarakan nada-nada positif, misalnya soal perdamaian, persaudaraan, kemanusiaan dan lain sebagainya. Dengan semakin banyak terlibat dalam gerakan-gerakan positif maka bukan saja kita terhindar dari paham radikalisme, tetapi juga dapat membantu karir kita.

Tentu saja ada banyak cara lain yang bisa dieksplorasi berdasarkan temuan di lapangan. Kiranya, dengan minimal empat langkah tersebut dapat membantu Generasi Z terhindar dari paham dan gerakan radikal. Semoga. 


\section{DAFTAR PUSTAKA}

Abdul Hayy bin Ahmad bin Muhammad bin al-'Akari al-Hanbali, Syadzarat ad-Dzahab fi Akhbari Man Dzahab, tahqiq: Abd al-Qadir al-Arna'uth dan Mahmud al-Arna'uth, Damasakus-Dar Ibn Katsir, 1406 H, juz, I

Abdurrauf al-Munawi, Faidl al-Qadir, Bairut-Dar al-Kutub al-IImiyyah, cet ke-1, 1415 H/1994 M, juz, V

Abu Hamid al-Ghazali, al-Iqtishad fi al-l'tiqad, Jeddah-Dar al-Minhaj, 2008 $\mathrm{M}$

Abu Hamid al-Ghazali, Faishal at-Tafriqah, dalam Majmu`ar-Rasail li al-Imam al-Ghazali, Bairut-Dar al-Kutub al-'Ilmiyyah, 2006 M

Abu Hasan Al-Mawardi, Al-ahkam Al-Sulthaniyah wa al-Wilayat al-Diniyah (Kuwait: Maktabar Dar Ibn Qutaibah, cet. Ke-1, 1989 M)

Abu Manshur Abd al-Qahir al-Baghdadi, Ushul ad-Din, tahqiq: Ahmad Syamsuddin, Bairut-Dar al-Kutub al-IImiyyah, cet ke-1. 1423 H/2003 M

Ahmad Dzajuli, Fiqih Siyasah: Implementasi Kemaslahatan Umat dalam Rambu-rambu Syari'ah (Bandung: Gunung Djati Press, 2000 M) 
Ali Abd al-Raziq. Al-Islam wa Ushul al-Hukm, Editor Muhammad 'Ammarah, al-Muassat al-Adabiyat Li al-dirasat wa al-Nasyar, 1972

Al-Ya`qubi, Tarikh al-Ya`qubi, juz, I, dalam http://www.alwarraq.com

Fahmi Huwaidi, al-Qur'an wa as-Sulthan, Bairut-Dar asy-Syuruq, cet ke-1, h. $1401 \mathrm{H} / 1981 \mathrm{M}$

Ibn Khaldun, Muqoddimah (Beirut: Dar Ihya al-turath al-Arabi, tth.)

Abul Fadal Jamaluddin Muhammad bin Makram bin Manzur al-Afriqi alMisri, Lisan alArab, Beirut : Daru Sadir

Ibn Taymiyah, al-Syiyasah al-Syar'iyah fi Islah al-Ra'iyah (Mesir: Darul Kitab al-Arabi, cet. Ke-4, 1969 M)

Ibnu Hajar al-Asqalani, Fath al-Bari Syarhu Shahih al-Bukhari, Bairut-Dar al-Ma'rifah, $1379 \mathrm{H}$, juz, XII

Ibnu Hibban, Shahih Ibni Hibban bi Tartibi Ibni Balban, Bairut-Muassah arRisalah, cet ke-2, 1414 H/1993 M, juz, 15

Ibnu Hibban, Shahih Ibni Hibban bi Tartibi Ibni Balban, Bairut-Muassah arRisalah, cet ke-2, 1414 H/1993 M, juz, 15

Ibnu Hibban, Shahih Ibni Hibban bi Tartibi Ibni Balban, Bairut-Muassah arRisalah, cet ke-2, 1414 H/1993 M, juz, 15

Ibnu Hibban, Shahih Ibni Hibban bi Tartibi Ibni Balban, Bairut-Muassah arRisalah, cet ke-2, 1414 H/1993 M, juz, 15

Ibnu Hisyam, as-Sirah an-Nabawiyyah, tahqiq: Judah Muhammad Judah, Kairo-Daru Ibn al-Haitsam, cet ke-1, 1427 H/2006 M, juz, 4

Ibnu Hisyam, as-Sirah an-Nabawiyyah, tahqiq: Judah Muhammad Judah, Kairo-Dar Ibn al-Haitsam, cet ke-1, 1428 H/2006 M, juz, II Ibnu Katsir, Tafsir al-Qur'an al-Azhim, Mesir-Dar Thayyibah, cet ke-2, 1420 H/1999 M, juz, III 
Ibnu Taimiyyah, Majmu' al-Fatawa, Mesir-Dar al-Wafa', cet ke-3, 1426 H/2005 M, juz, XIII

Jalaluddin as-Suyuthi, Tarikh al-Khulafa', Bairut-Dar Ibnu Hazm, cet ke-1, $1424 \mathrm{H} / 2003 \mathrm{M}$

Ath-Thahawi, Syarh Ma'ani al-Atsar, tahqiq: Muhammad Zuhri an-Najjar dan Muhammad Sayyid Jad al-Haq, Bairut-Alam al-Kutub, cet ke-1, 1414 H/1994 M, juz, IV

Al-Imam Abi Zakaria Yahya Ibn Syarif Nawawi. Riyadl Ash Shalihin. Tth.

Philip K. Hitti, History of The Arab, penerjemah R. Cecep Lukman Yasin dan Dedi Slamet Riyadi, Jakarta-Serambi, cet ke 1 Juli 2013

Sulaiman bin Ahmad bin Ayyub Abu al-Qasim ath-Thabrani, al-Mu'jam alKabir, tahqiq: Hamdi bin 'Abd al-Majid as-Salafi, Maushul-Maktabah al-'Ulum wa al-Hikam, cet ke-2, 1404 H/1983 M, juz, XII

Wahbah az-Zuhaili, al-Figh al-Islami wa Adillatuhu, Damaskus-Dar al-Fikr, cet ke-2, 1405 H/1985 M, juz, VI 

Buku ini mengajak para guru mengerti dunia Gen Z, mulai dari karakteristik sampai cara belajarnya, tetapi juga langkah-langkah apa yang perlu dipersiapkan guru menghadapi Gen Z ini. Karena menjawab beragam pertanyaan keagamaan, buku ini juga disertai dengan rujukan literatur yang padat dan bisa dipertanggungjawabkan. Sebagai upaya untuk mengarusutamakan Islam rahmatan lil alamin.

\section{Profil Wahid Foundation}

Wahid Foundation diluncurkan 7 September 2004, di Jakarta. Didirikan untuk memajukan visi kemanusiaan dari KH Abdurrahman Wahid (Gus Dur) dalam memajukan pengembangan toleransi, keberagaman dalam masyarakat Indonesia, meningkatkan kesejahteraan masyarakat miskin, membangun demokrasi dan keadilan fundamental, dan memperluas nilai-nilai perdamaian dan non-kekerasan di Indonesia dan di seluruh dunia.

Baik di tingkat regional dan global, Wahid Foundation memfasilitasi dialog dan membangun pemahaman antara Islam dan agama-agama dan budaya lain, termasuk antara mereka yang hidup di dunia Muslim dan mereka yang tinggal di Barat. Di Indonesia, Wahid Foundation mendorong munculnya pemikir muda dan aktivis untuk mewujudkan komitmen dan visi Gus Dur. Wahid Foundation menyelenggarakan pendidikan untuk pemuda, peningkatan kapasitas bagi ulama Muslim untuk menghasilkan pemahaman lintas-agama, lintas-budaya, dan dialog lintas-etnis, dan mempromosikan mereka untuk berpartisipasi secara aktif dalam proses membangun kesejahteraan ekonomi, keadilan dan pemerintahan yang baik.

\section{WAHID FOUNDATION}

Griya Gus Dur, Jl. Taman Amir Hamzah No. 8

Pegangsaan Menteng Jakarta Pusat 10320

Telp : +62 $21-3145671$

Faks : +62 $21-3928250$

Media@wahidinstitute.org

www.wahidfoundation.org

FB Wahid Foundation

Twitter @Wahidfoundation

IG @Wahidfoundation 